UNIVERSIDADE DE SÃO PAULO

FACULDADE DE CIENCIAS FARMACEUTICAS

Curso de Pós-graduação em

Fármaco e Medicamentos

Área de Elaboração do Medicamento

\title{
INFLUÊNCIA DE AGENTES SUSPENSORES E EDULCORANTES NA SUSPENSÃO DE ESTEARATO DE ERITROMICINA
}

TELMA MARY SAKUDA

Dissertação para obtenção do grau de MESTRE

Orientador:

Prof. Dr. JOÃO HAIKAL HELOU

São Paulo 
AOS MEUS PAIS

TOSHIAKI E TERESA,

que, com compreensão e amor, me ensinaram a escolher meus prōprios caminhos.

AO MEU MARIDO

TARO,

pela dedicação e amizade, possibilitando transpor

os obstāculos mais difíceis.

ÁS MINHAS FILHAS

pe10 carinho e compreensão. 
AO PROF. DR. JOAO HAIKAL HELOU

pela orientação, incansāvel apoio, constante incentivo e empenho durante a realização deste trabalho, apesar de todo o complexo de suas atividades. 
Ao Farmacēutico Toshiaki Sakuda e técnico Rikio Sakuda, pela orientação na escolha da profissão farmacêu tica.

A Profa Ass. Dra Takako Saito, pela amizade sincera, apoio constante, valiosas sugestões e revisão deste trabalho.

Ao Prof. Assistente Hélio José Bertuzzi, pelo inestimável auxỉio prestado na parte experimental.

Aos Profs. Ass. Drs. Jamil Zamur e Reynaldo Nacco e Profas Assistentes Ida Caramico Soares e Mitsuko Taba Ohara, pela amizade e colaboração.

A Sra Margarida de 01 iveira, pelo empenho na da tilografia dos originais.

Ao técnico de laboratório Jamil Anéas Gomes, pe la ajuda na parte experimental.

A Srta Aparecida Porto, pelo auxîlio na datilografia.

As Farmacēuticas e Funcionários do ConfAR, pela permissão na utilização do Laboratório.

A bibliotecāria Moema R. dos Santos, da Biblioteca do Conjunto das Quimicas, pela revisão e normalização das referéncias bibliogräficas.

A PREDIMAR, Companhia de Produtos Quimicos BONO MIA, TRINCA Indūstria e Comércio S.A., pelas amostras.

A todos que colaboraram na execução do presente traba 1 ho. 
1 Introdução . . . . . . . . . . . . . . . . . . . . . . 1

2 Revisão da literatura . . . . . . . . . . . . . . 4

2.1 Generalidades................. . . 4

2.2 Fatores físico-quimicos . . . . . . . . . . . 5

2.2.1 Energia livre . . . . . . . . . . 5

2.2.2 Molhabilidade . . . . . . . . . 6

2.2.3 Crescimento de cristais . . . . . . 10

2.2.4 Sedimentação . . . . . . . . . . 12

2.2.5 Reologia . . . . . . . . . . . 15

2.2.6 Estabilidade física das suspensões. . . 18

2.3 Formulação

3 objetivo . . . . . . . . . . . . . . . 27

4 Materiais e métodos . . . . . . . . . . . . . 28

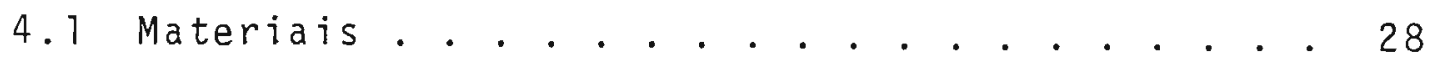

4.1.1 Matérias-primas . . . . . . . . . 28

4.1.2 Equipamentos . . . . . . . . . . . 29

4.2 Mëtodos . . . . . . . . . . . . . . . 30

4.2.1 Estudo de alguns adjuvantes farmacotécnicos utilizados na formulação

de suspensões . . . . . . . . . . 30

4.2.1.1 Influencia dos tensoativos. . 30

4.2.1.2 Influēncia dos edulcorantes. . 30

4.2.1.3 Influēncia dos agentes suspensores . . . . . . . . . 32

4.2.2 Estudo de estabilidade das suspensões

de estearato de eritromicina. . . . . 33

4.2.2.1 Estudo prēvio.... = . . . 33

4.2.2.1.1 Förmula das suspensões . . 33 
4.2.2.1.2 Técnica de preparação. . . 34

4.2.2.1.2.1 Preparação do meio suspensor $\quad . \quad . \quad . \quad . \quad . \quad 34$

4.2.2.1.2.2 Dispersão de estearato de eritromicina . . . 35

4.2.2.1.2.3 Preparação da suspensão. 35

4.2.2.2 Estudo definitivo das suspen sões............ . . 36

4.2.2.2.1 Fórmulas das suspensões. . . 36

4.2.2.2.2 Tëcnica de preparação. . . 37

4.3 Determinação de parāmetros analîticos... . . 43

4.3.1 Tamanho de partīculas . . . . . . 4 43

4.3.2 Volume e densidade aparentes . . . . . 43

$4.3 .3 \mathrm{pH}$. . . . . . . . . . . . . . . . 43

4.3.4 Densidade ............. . . 44

4.3.5 Viscosidade ............... 44

4.3.6 Aspecto da suspensão.......... . 44

4.3.7 Volume do fármaco disperso....... . 44

4.3.8 Caracterīstica de ressuspensão . . . . 45

4.3.9 Doseamento do antibiótico . . . . . 45

5. Resultados . . . . . . . . . . . . . . . 48

6 Discussão . . . . . . . . . . . . . . . . . 70

7 Conclusões . . . . . . . . . . . . . . . . . 85

8 Referēncias bibliogrāficas . . . . . . . . . . . 86

9 Resumo . . . . . . . . . . . . . . . . . . . 98

10 Summary . . . . . . . . . . . . . . . . . 99 


\section{INTRODUÇAO}

De acordo com o Catálogo Brasileiro de Produtos Farmacéuticos da Secretaria Nacional de Vigiláncia Sanitāria do Ministério da Saūde, cerca de 38.000 apre sentações farmacēuticas estavam registradas no Brasil em agosto de 1984. Entre estas, aproximadamente 3.700 continham em sua formulação antibióticos com atividade sistēmica classificada como "sem associações".

Segundo Korolkovas, (61), "Antibiōticos são substâncias químicas especîficas, derivadas de organis mos vivos ou produzidas por eles, bem como seua anälogos estruturais obtidos por sintese, capazes de inibir processos vitais de outros organismos, mesmo em concen trações diminutas". Conforme o miesmo autor, entre as receitas aviadas, o maior indice está entre os antibiō ticos, chegando a ser de $12 \%$ nos Estados Unidos. KENNEDY e colaboradores (58), pelas pesquisas efetuadas em 1982, observaram ser os grupos mais frequentes utilizados em hospitais Norte-americanos aqueles represen tados por cefalosporina, penicilina, eritromicina e te traciclina.

A eritromicina pertence à classe do grupo macrolidico, sendo comercializada sob a forma de esteara 
to, estolato, gluceptato, lactobionato, etilcarbonato e etilsuccinato. 0 espectro de ação deste fármaco abrange a maioria das bactērias gram-positivas e alguns orga nismos gram-negativos.

No mercado brasileiro, conforme o Catálogo anteriormente mencionado, estavam registradas 373 especia 1 idades contendo a eritromicina. Deste total, 71 são comercializados sob a forma de suspensão.

A forma farmacéutica como suspensão tem grande importāncia na terapēutica, uma vez que se presta para administração de färmacos hidro-insolūvais sob forma $1 \underline{i}$ quida. Esta pode ser utilizada por via oral e paranteral ou ap̣licação tōpica. A técnica de preparação envol vida na obtenção desta apresenta particularidades, não podendo obedecer an procedimento ünico, fato comum na farmacotécnica, em geral. Neste caso, as variações ine rentes ao fármaco hidro-insolüvel dizem respeito ao tamanho e forma de particulas, bem como à sua densidade.

Consequentemente, a formulação deverā compatibilizar estas propriedades com a estabilidade físico-quí mica deste princípio ativo durante a vida útil do produ to.

Consideram-se como características de estabili dade de suspensão a dispersão uniforme de partículas no 
meio dispersante, que seja estável ao longo do tempo de vida ütil, ou sistema heterogēneo, com separação de fases, mas que seja de fācil redispersão, além das proprị edades reológicas. Para atender a tais requisitos recorrem-se ao emprego de adjuvantes que propiciem determinadas caracteristicas relacionadas com a viscosidade e densidade do meio dispersante, assim como a mothabili dade das partículas pela fase externa.

Todo empenho no desenvolvimento farmacotécnico deve visar todas as caracteristicas de estabilidade,pro curando associar ao requisito relacionado com a eficácia e segurança ao paciente, a beleza farmacéutica. 


\section{REVISÃO DA LITERATURA}

\subsection{Generalidades}

As suspensões são sìstemas heterogêneos constituídos por duas fases: a: fase externa, dispersante ou contínua, que consiste de 1íquidos; e a fase interna, dispersa ou descont nua, formada de partículas sōlidas com características de mí nima ou nula solubilidade na primeira.

As suspensões, bem como as emulsões e aerosōis, são consideradas dispersões grosseiras e o tamanho das partículas varia entre 0,1 a algumas centenas de micron $(12,22)$.

As suspensões farmacēuticas classificam-se em três grupos, segundo as vias de administração: oral, parenteral e dermatológica (80).

Em suspensões orais a quantidade da fase sólida dispersa pode variar muito. Em geral, quando dosificadas, a concentração é da ordem de 125 a $500 \mathrm{mg}$ por dose de 5 a $15 \mathrm{ml}$.

Săo diversas as razões que justificam o emprego de medicamentos sob a forma da suspensão. Pode ser decorrēncia da insolubilidade do princípio àtivo no veículo utilizado, ou por necessidades impostas em função de sabor desagradável do fārmaco na preparação oral, ou por questões de eficiēncia té rapēutica, prolongando-se o efejto farmacológico $(62,87)$.

E por isto que este tipo de preparação medicamentosa deve atender a certos requisitos. Segundo SCHEER (97): as suspensões devem ter as seguintes caracterīsticas: o fármaco suspenso não deve sedimentar-se rapidamente, mantendo estabi lidade do sistema com pequena ou nula separacão de camadas. Entretanto, pode ocorrer sedimentação rāpida, mas com fäcī 
ressuspensão quando submetido à agitação. Portanto, não ocorre compactação.

Ao 1 ado disto, a suspensão não deve ser muito viscosa, dificultando sua saîda do recipiente. Como caracterīs tica outra a suspensão deve ser quĩmica, biológica e fisica mente estāvel durante a vida útil da mesma.

Considera-se também, como requisito importante a "elegãncia ou beleza farmacéutica", conceito que envolve a cor, odor, sabor e aspecto, cujas caracteristicas propiciam a aceitabilidade pelo paciente (1). Portanto, a suspensão deve permitir ao consumidor o uso de doses uniformes, igua is e terapeuticamente ativas, com propriedades organolépticas agradāveis (89).

A fim de atender a todas estas características, exi ge-se estudo farmacotécnico pormenorizado. Sendo suspensão sistema termodinamicamente instāvel, este possui grande nūmero de variāveis, as quais podem influir na escolha do pro cesso da preparação, com vistas à estabilidade do produto.

\subsection{Fatores físico-quĩmicos}

\subsubsection{Energia livre}

Entre fatores físico-quỉmicos deve-se dar ènfase à energia 1 ivre.

Ao se dividir um sōlido em partículas cada vez menores, aumenta-se a ārea da superfície, o que conduz a aumento de energia livre das partículas.

A energia livre da superfĩcie pode ser representada pe la equação $(102)$ : 


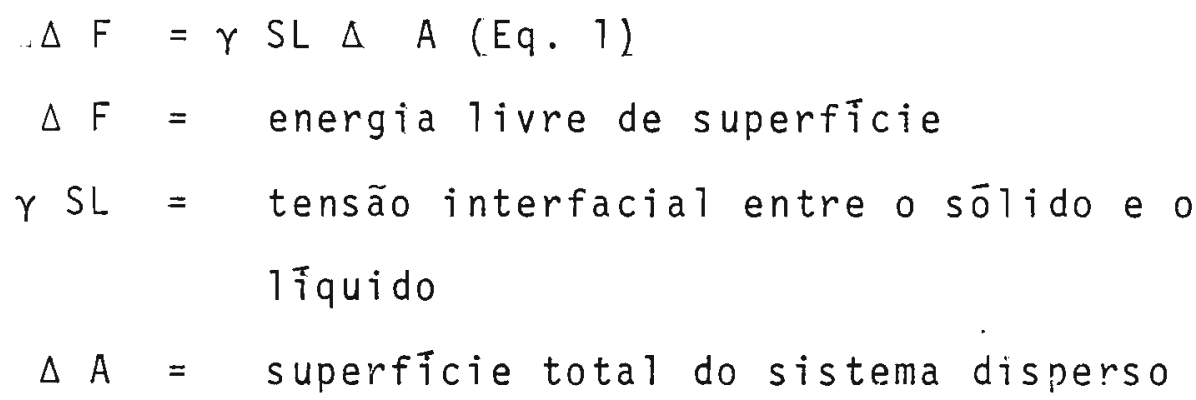

A fim de diminuir a energia livre, as partículas tendem a se reagrupar, reduzindo, portanto, a sua ārea. Este fenōmeno está presente tanto nos sōlidos como nos 1 ĩquidos subdivididos no meio gasoso ou líquido e, por esta razão, suspensões são sistemas termodinämicamente instāveis, em que as partículas têm a tendência de se aderir para reduzir sua energia livre (100).

Hā maior estabilidade quando $\Delta F$ tende a zero. Pa ra isso pode-se diminuir a tensão interfacial ou ārea inter facial (91). o emprego de agentes tensoativos visa redução da tensão interfacial, embora seja muito difícil essa redução até zero (1).

\subsubsection{Molhabilidade}

Durante a formulação de suspensão considera-se como fase critica o momento da incorporação das particulas sō lidas no veículo. Neste momento, pode ocorrer o fenómeno de nominado: flutuação ou cremagem. Isto se deve a caracterīsticas de baixa molhabilidade do sólido, ou pouca afinidade pela fase liqquida. O que ocorre é que a camada de ar que envolve o sōlido não consegue ser deslocada pelo líquido,pro vocando a formação de aglomerados de partículas, que flutuam 
na superfície do līquido, sendo, portanto, de difícil disper são no veículo.

A molhabilidade de um sōlido por um lîquido é expres sa em termos de āngulo de contato, no ponto em que se juntam as fases sólida e líquida com a do ar (1) (7). Por isto, as tensões interfaciais envolvidas na interface correspondem a

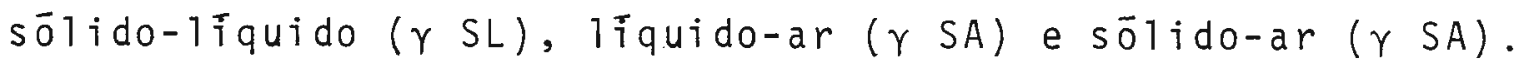
(114).

$$
\gamma S A=\gamma S L+\gamma L A \cos \theta(E q \cdot 2)
$$

Relacionando-se a Eq. 2 com a da Dupré (Eq. 3) onde w SL é o trabalho de adesão entre o sólido e o líquido (trabalho requerido para separar $1 \mathrm{~cm}^{2}$ interfaces sólido-ar e li quido-ar). Obtēm-se a Eq. 4. Esta, por sua vez, é a equação de Young.

$$
\begin{aligned}
& \omega S L=\gamma S A+\gamma L A-\gamma S L(e q \cdot 3) \\
& \omega S L=\gamma S L+\gamma L A-\cos \theta+\gamma S A-\gamma S L(E q \cdot 4) \\
& \omega S L=\gamma L A(1+\cos \theta)(E q \cdot 5)
\end{aligned}
$$

Neste caso, três possibilidades existem:

$\omega S L=\gamma L A, \cos \theta=0$ ou $\theta=90$

$\omega S L \leq \gamma L A, \theta>90$

$\omega S L \geq 2 \gamma L A, \cos \theta \geq 1$ ou $\theta=0$ ou negativo.

Pode-se deduzir, portanto, que a molhabilidade de um sōlido por um líquido será tanto maior quanto menor o àn gulo de contato. Daí a possibilidade de expressar a molhabilidade através da seguinte equação: 


$$
\cos \theta=\frac{\gamma S-\gamma S L}{\gamma L} \quad(E q, 6)
$$

Esta fōrmula ē somente vālida para substāncias uniformes quanto ao tamanho e forma, devendo esta ser esférica. Porēm, como na maioria dos casos estas características inexistem na fase interna, dever-se-ia adicionar à equação-mode 10 o fator relacionado com a irregularidade da superfície da partícula. O àngulo de contato da parafina, por exemplo, é de 1050; entretanto, o eficaz para impregnação textil pode ser acima de 1450 (86).

Em função da molhabilidade, as substāncias sōlidas são classificadas em hidröfilas e lipöfilas. Nestes dois ca sos o àngulo de contato é agudo. Quando superior a 900, tra ta-se de substāncias hidrōfobas para solventes polares e subs tâncias liófobas para solventes apolares $(1,87)$ :

Quando se prepara suspensão de substância hidrōfoba em meio aquoso. as partículas flutuam na superfície devido à presença do ar aderido às partículas secas ou molhadas insuficientemente.

De acordo com as equações anteriormente comentadas, diminuindo-se as tensões interfacial e superficial, pode-se diminuir o ànguio de contato. Portanto, a adição de agentes tensoativos molhantes pode evitar a flutuação. Também, em algumas ocasiões, é recomendada a adição de macromoléculas fortemente hidrófilas como a carboximetilcelulose sódica e goma arābica, ou substāncias hidrōfilas insolūveis, tais como a bentonita, Veegum ${ }^{R}$, Aerosi $7^{R}$ e hidrōxido de âlumínio (l, $86,87)$. 
Em geral, è de difícîl execução a medida do āngulo de contato. Entretanto, tal dado ê ütil na compreensão do fenômeno da molhabilidade. E por isto que ARANCIBIA (1) e RIGAMONTI e RUGGINENTI (91) comentam sobre tal importância, mas enfatizam a praticidade de pesquisa empirica do uso de tensoativos visando obtenção de suspensão.

Na prática, em geral, empregam-se procedimentos em piricos muito simples e pouco rigorosos quando se deseja co nhecer a molhabilidade de substância sōlida ou : capacidade umectante de determinado tensoativo. ZACEK (112) para deter minar a molhabilidade de pó em líquido recomenda verter este sobre o pó previamente envolvido em gase hidrófila. Desta forma, consegue-se avaliar a porcentagem da substáncia que foi arrastada pelo liqquido, através da gaze, em condições padronizadas, pois, em função de maior ou menor capaci dade umectante, haverá arraste proporcional do sólido. outra forma para determinar esta característica baseia-se na prova de DRAVES (1), que consiste em medir o tempo necessário para submersão de um peso conhecido de algodão hidrófi10 em solução dispersante $(1,87)$. Pela técnicá de RIGAMON TI e RUGGINENTI ( 91 ), efetua-se observação visual do proces so de penetração do pó no interior do veículo de maneira a obter dádos comparativos entre vários tensoativos.

Entre métodos menos empīricos, existe a técnica de CARAMELLA e colaboradores (11). Estes, usando sulfametaxipi ridazina e seu derivado $\mathrm{N}$-acetilado frente a vārias concentra ções de diferentes tensoativos, determinaram o volume de sedimento, turbidez do liquido sobrenadante e a molhabilidade eletroforética das partículas. 


\subsubsection{Crescimento de cristais}

Outro fenōmeno que influencia na estabilidade fís ca de suspensões è o crescimento de cristais. Este é devido ao a umento do tamanho das partículas. Segundo HIGUCHI (48), este fenomeno tem importância pelo fato de grandes particulas serem menos uniformemente dispersas, alēm de apresentarem se dimentação com maior velocidade e dificultarem a redispersão. Por outro lado, podem dar textura arenosa à suspensão, ternando-a imprōpria para aplicação tópica, especialmente oftā I mica. Finalmente, a mudança no tamanho de partícula conduz a alterações de viscosidade e propriedades reológicas da sus pensão.

0 crescimento de cristais em suspensão ocorre somente nos casos em que a atividade termodinâmica desta substāncia, na fase líquida, é maior que a das partículas sōtidas. Em outras palavras, é preciso que a concentração na solução seja maior que a solubilidade da substância. Este estado de supersaturação pode ser alcançado pela dissolução de substān cia, cuja forma, termodinamicamente, seja mais energētica, ou pelo resfriamento da solução saturada $(1,48,87)$.

As causas que influenciam o crescimento de cristais são variações de temperatura, polimorfismo, presença de mate riais cristalinos ou amorfos e diferentes tamanhos de cristais dispersos (86). O abaixamento térmico de suspensão pode diminuir o coeficiente de solubilidade da substāncia (87).

Os cristais polimorfos de uma substância apresentam diferenças estruturais, sendo que cada forma desta pode ter característica de solubilidade específica. Há polimorfismo 
em muitos fārmacos. O barbital apresenta trēs formas; o ace tato de cortisona, trés; nicotinamida, quatro. os sólidos, no estado amorfo, apresentam maior solubilidade do que as correspondentes formas cristalinas. E, ainda, a diferença de tamanho de cristais suspensos influencia a solubilidade, pois será tanto maior, quanto menor o tamanho dos mesmos.

A diferença de solubilidade entre dois cristais de diferentes tamanhos pode ser considerada e calculada com base na equação de Ostwald-Freundlich (87).

$$
\log \frac{S}{S_{0}}=\frac{2 \gamma V}{2.303 R T}\left(\frac{1}{r}-\frac{1}{r_{0}}\right) \quad E q \cdot 6 .
$$

onde

$S$ e $S_{0}=$ solubilidade das partículas com diàmetros $r$ e $r$ respectivamente onde $r<r_{0}$.

$$
\begin{aligned}
& V=\text { volume molar }\left(\mathrm{cm}^{2}\right. \text { por molēcula grama) } \\
& R=\text { constante dos gases } \\
& T=\text { temperatura absoluta } \\
& \gamma=\text { tensão interfacial }
\end{aligned}
$$

E substituindo volume molar pela relação molécula-grama,

$$
\begin{aligned}
& M / p \quad \text { temos: } \\
& \log \frac{S}{S_{0}}=\frac{2 \gamma}{2.303 R T} \frac{M}{p} \cdot\left(\frac{1}{r}-\frac{1}{r_{0}}\right)
\end{aligned}
$$

De acordo com as equaçöes 6 e 7 , pode-se diminuir o crescimento de cristais pelo abaixamento da tensão interfaci a1, o que se consegue pelo emprego de tensoativo adequado. Tambēm é importante escolher para formulação a forma crista- 
lina mais estāvel e partículas com pouca variação de tamanho.

\subsubsection{Sedimentação}

Um outro fator que influencia a estabilidade de suspensão ê a sedimentação. O processo de sedimentação è a ten dēncia das partículas suspensas num meio líquido, de se diri girem para o fundo do recipiente em função da ação da força de gravidade atuando sobre as mesmas. A velocidade de sedimentação estā diretamente relacionada com as características das fases dispersa e dispersante. Quanto menor for o tamanho e densidade das partículas e maior a viscosidade do veículo, a velocidade de sedimentação serā menor. Este fenōmeno è ex presso em termos da 1ei de Stokes (102):

$$
\begin{aligned}
& V=\frac{d s}{d t}=\frac{2 g r^{2}\left(d_{1}-d_{2}\right)}{9} \quad(E q \text {. 8) } \\
& r=\text { raio de partículas } \\
& d_{1}=\text { densidade de partículas } \\
& d_{2}=\text { densidade da fase dispersante } \\
& g=\text { aceleração da gravidade } \\
& \eta=\text { viscosidade da fase continua }
\end{aligned}
$$

A lei de Stokes è somente vālida para partīculas per feitamente esfēricas, rīgidas e de tamanho uniforme, constituindo suspensão muito di luî̀da, em que a sedimentação ocorra com velocidade tal que não provoque turbulēncia. As partīcu las não devem interferir uma com as outras, devendo sedimentar-se individualmente. Além disto, deve ser desprezível o efeito elétrico entre as partículas sólidas e a fase disper- 
sante. Nas suspensões farmacēuticas não são encontradas tais condições, pois, em geral, são mais concentradas e as partīculas não são uniformes quanto ao tamanho e forma, além de haver interação entre as fases. A lei de Stokes não expressa a verdadeira velocidade de sedimentação das suspensões farmacēuticas, porēm permite conhecer fatores envolvidos na instabilidade das mesmas. HIGUCHI (48) aplicou a lei Kozeny às suspensões mais concentradas e obteve a fórmula para determinar a velocidade de fluxo linear. Para isto imaginou ser o fenōmeno da sedimentação movimento da fase líquida ex terna, através de um leito formado pela fase interna sólida.

$$
\begin{aligned}
& H=\frac{\left(d_{1}-d_{2}\right) g \varepsilon^{3}}{\left(K \eta S v^{2}\right)(1-\varepsilon)} \quad(E q \cdot 9) \\
& \mathscr{H}=\text { velocidade de fluxo linear } \\
& \varepsilon=\text { fator de porosidade do leito sólido } \\
& 1-\varepsilon=\text { volume da fase interna } \\
& S V=\text { área superficial especīfica em } \mathrm{cm}^{2} \text { por } \mathrm{cm}^{3} \text {. } \\
& K=\text { constante de Kozeny que } \bar{e} \text { aproximadamente } \\
& \text { igual a } 5 \text {. } \\
& \text { E os termos } d_{1}, d_{2}, g, \eta \text { têm o mesmo sign } \underline{i} \\
& \text { ficado da Equação } 8 \text {. }
\end{aligned}
$$

Esta retação é sujeita tambēm a vārias limitações, pois, entre outros fatores, exige que a porosidade se mantenha constante, que as partículas tenham dimensão muito semeThante entre si, que a diferença de pressão nas duas extremi dades da camada seja elevada e que os fenómenos de superfície sejam desprezíveis (87). 
A equação de Stokes e Higuchi são fundamentalmente dị ferentes quanto à interpretação física, mas ambas tēm vārios termos em comum. Devem ser consideradas pelo formulador com o objetivo de obter suspensão que tenha menor velocidade de se dimentação. Este estado de estabilidade serā possível, quando a diferença entre as densidades da fase contínua e descontínua tender a zero e o tamanho das particulas for inferior a $5 \mu \mathrm{m}$ e a viscosidade do sistema for elevada.

Nas suspensões farmacēuticas, o tamanho de partícula estā entre 1 a $50 \mu \mathrm{m}(80)$. HIESTAND (46), no seu trabalho de revisão sobre suspensão, admite haver partículas de diàmetro menor que $0,1 \mu$. ARANCIBIA (1), por outro lado, menciona dimensões maiores, de até centena de micrōmetro. A indūstria farmacêutica, com vistas ao enquadramento do tamanho de partịculas às especificações ideais, emprega diversos procedimen tos para reduzir a dimensão das mesmas. Para isto, utilizamse a micropulverização, a atomização e a precipitação controlada com u1tra-som $(1,80)$.

A equação de Stokes e a de Kozeny Higuchi indicam ser a viscosidade do meio fator interferente na velocidade de sedimentação.

A viscosidade ē expressa atravēs da equação de Einstein (Eq. 11), podendo ser diferente nos casos de suspensão modera damente concentrada (35) (Eq. 12).

$$
\begin{aligned}
\eta & =\eta_{0}(1+k \theta) \quad(E q \cdot 11) \\
\eta & =\eta_{0}(1+a \theta+b \theta+c \theta \ldots) \\
& \text { onde: } \\
\eta_{0} & =\text { viscosidade da fase contínua }
\end{aligned}
$$




$$
\begin{aligned}
a=k= & \text { constante, cujo valor e } 2,5 \\
\theta= & \text { fração do volume da fase dispersa } \\
\text { b. e c }= & \text { são constantes que dependem da forma } \\
& \text { e da interação entre elas e com o meio. }
\end{aligned}
$$

Ambas as equações têm aplicação, quando o sistema apre senta viscosidade newtoniana, o que não ocorre com suspensões medicamentosas. Por esta razão, é importante desenvolver alguns conceitos fundamentais sobre viscosidade e caracteristicas de fluxo dos sistemas não newtonianos.

\subsubsection{Reologia}

A fim de compreender a importāncia que representa o agente suspensor na formulação de suspensão, diversos estudos foram efetuados no tocante à reologia dos líquidos. A propri edade de fluxo de um líquido é expressa segundo a equação de Newton, como produto do coeficiente de viscosidade (1) pela velocidade de fluxo:

$$
\underline{F}=\eta \frac{d v}{d r} \quad(E q \cdot 13)
$$

Os lĩquidos que apresentam relação linear entre a for ça aplicada e velocidade são conhecidos como 1 iquidos newtoni anos. A lei de Newton só é vālida para líquidos de composição simples e viscosidade relativamente baixa. Enquadram-se entre estes a água, glicerina, cloroförmio e soluções verdadeiras $(1,75)$. Em líquidos de composição múltipla interferem ou tros fatores, a lém dos expressos pela lei de atrito (87). 
A maioria das dispersões farmacêuticas, tipo suspensão, não segue a lei de Newton c100L. E por isto que são em pregados viscosimetros rotacionais na determinação desta caracterîstica em suspensões farmacéuticas $(75)$.

Ao se estudar as propriedades das suspensões, em vis cosîmetros rotacionais, obtēm-se reogramas de caracterīsticas correspondentes aos do tipo plástico, pseudo-plástico e dila tante $(24,962$. Entretanto, para líquidos newtonianos o reograma é uma linha reta que passa pela origem. Sendo assima inclinação da reta indicarä a viscosidade do sistema, pois, quanto maior aquele valor, menor será a viscosidade. Para suspensões que são sistemas heterogêneos, as propriedades re ológicas dependem da velocidade, do tempo a que o material foi submetido à deformação e, tambēm, em função do tratamento prēvio a que tenfa sido submetido ( 12 .

Liquidos ou sistemas que apresentam o fluxo tipo plās tico denominam-se corpos de Binghan. Caracterizam-se por apresentar certa resistência inicial para fluir, mas apre sentando escoamento a partir de uma determinada força mínima, denominada valor de cedência e a substância comportar-se-á como matēria elästica (87). Este fenômeno ocorre devido à existēncia de macromoléculas distribuĩdas em forma de malha, que não sendo muito rígidas, romperiam a trama, quando o sis tema começasse a fluir. No sistema plästico o reograma não passa pela origem, embora o mesmo seja uma reta na sua maior parte. o ponto de intersecção da projeção desta porção reti Tinea sobre a abcissa corresponde ao valor de cedencia. No caso de suspensão com sistema floculado, as partĩculas mantêm-se juntas por forças de London Van der wails, tambëm de- 
nominadas forças de floculação, sendo de valor menor que o de cedéncia $(1$ L.

Para os sistemas pseudo-plásticos, o reograma passa pela origem ou muito próximo dela e a velocidade de fluxo não aumenta linearmente com a força $F$. Conseqüentemente, a viscosidade não permanece constante. Este fenōmeno deve-se às molēculas de cadeias longas ou estruturas complexas, que se encontram desordenadas e em forma de rede, mas que, quan do submetidas a uma força, vão se alinhando em direção a es ta, por apresentarem menor resisténcia do fluxo. Portanto, há diminuição de viscosidade à medida que aumenta a velocidade $(75)$.

No tipo dillatante hā aumento de viscosidade quarido o sistema è submetîdo à força e è mais fluído no estado de repouso. E o fenómeno inverso em relação aos sistemas com características pseudo-plásticas. O fluxo dilatante é propriedade presente nas suspensões desfloculadas com elevado conteüdo sōiìdo (1).

Certos sistemas não newtonianos possuem a proprieda de de passar do estado de gal, em repouso, ao de sol, apōs agitação. Isto se deve à ruptura da sua estrutura, pela agi tação, com característica de reversibilidade. Este fenōmeno é conhecido por tixotropia. O reograma dos sistemas tixotrōpicos apresenta grāfico onde a curva do estado de gel para o sol não coincide com o estado de sol para o gel (75).

DONDI e colaboradores (24) e PRISTA e ALVES (87), consideram a tixotropia um outro tipo de fluxo. ARANCIBIA (1) a MOES (75) consideram, ainda, outra caracteristica adi- 
cional nos sistemas plästicos, pseudo-plāsticos ou dilatantes.

Através dos estudos reológicos, CARAiviELLA e colaboradores $(12,13 L$ previram e avaliaram a estabilidade física de algumas sulfas e antibióticos e seus correspondentes meios suspensores. FD̈ERNZLER e colaboradores (36) estuda ram as características tixotrōpicas das suspensões de bento nita e atalpugita ativada, a fim de minimizar ou eliminar a sedimentação e coagulação da fase dispersa.

\subsubsection{Estabilidade fĩsica das suspensões}

Diversos aspectos físicos relacionados com a estabi 1 idade física de suspensões foram estudadas por muitos pesquisadores $(14,15,16,27,29,45,46,47,53,70,71,110)$. 0 aspecto mais facilmente detectado consiste na sedimentação das partículas. Estas, quando em suspensão, podem sedi mentar-se isoladamente ou de forma aglomerada. Q quando as partículas se associam fracamente, resultando aglomerados em forma de flocos, dão origem a sedimento não compactado, o que caracteriza a suspensão do tipo floculado. Neste caso, a velocidade de sedimentação é grande, deixando sobrenadante limpido e com volume grande de sedimento. Este tipo de suspensão é facilmente redisperso. Outro tipo, com partīcu las separadas, mantendo sua individualidade durante o processo de sedimentação, corresponde à suspensão desfloculada. Neste caso, ocorre sedimentação diferencial em função do ta manho de partículas, sendo inicialmente das maiores. A velocidade de sedimentaçäo è mais baixa que no outro tipn, por tratar-se de partículas individualizadas. E por isto que apresenta camada límpida do sobrenadante. O sedimento que. 
ocupa pequeno volume $\vec{e}$ compacto e $\bar{e}$ de dificil redispersão. Este fenômeno ẽ denominado compactação (97). Em suspensão farmacéutica deve-se evitar tal caracteristica, pelo fato de o sedimento ser o färmaco ou conter o princípio ativo adsorvido nas particulas e isto prejudica a uniformidade de dose, mesmo com agitação vigorosa do conteūdo do frasco, an tes do uso. Tal fato acaba por comprometer a eficácia terapêutica.

Independente do tipo de sedimento formado no proces so de instabilização das suspensöes, devem ser consideradas as forças de repulsão e atração das particulas $(72,88,98)$. Segundo NASH (80), as forças de repulsão localizam-se na su perficie, podendo ser de carga negativa ou positiva. Estas podem surgir devido a ionização das molēculas da superfície, ou por adsorção de ions do meio 1īquido (872. Os ions da solução, ou as moléculas do lîquido dispersante, formam ao redor das partículas uma dupla camada eletrostātica (10). Quando a carga da superficie de maioria das partículas for negativa, atrairá da solução ions positivos, formando uma camada ao redor, chamada fixa, estacionäria, ou de stern. Dutros ions de carga oposta, ou não, localizados nas imedia ções das partículas, formam uma outra camada chamada difusa ou de GOY. As forças de atração a que são submetidas as par tículas são do tipo London-Van der Walls. Estas forças con duzem a um potencial de energia de repulsão (Vr) e atração (Va) entre as partículas, que resultarā no potencial de ener gia total (Vt), como mostra o grāfico seguinte: 


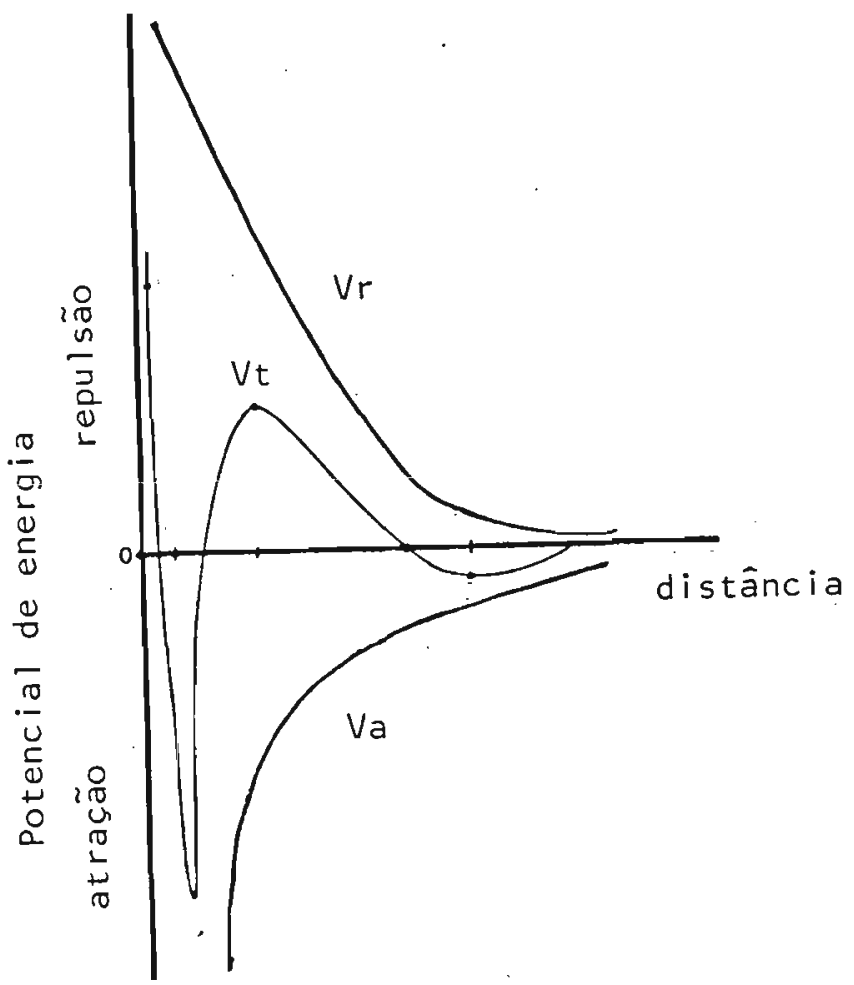

Portanto, quanto menor for o potencial de repulsão, maior será a probabilidade de floculação das partículas (98). Evidentemente, quando isto ocorre, hā predomināncia do potencial de energia de atração. Assim, as partículas tendem a atrair-se atravēs das forças de London-yan der Wa11s, man tendo distāncia de separação suficiente, permitindo a forma ção de estruturas abertas ou floculadas (9.1).

o controle da floculaçăo das partîculas em suspensão pode ser feito reduzindo-se o potencial zeta $(14,54$, 56, 82). Este valor é calculado através da mobilidade eletroforētica das partīculas em campo elëtrico e representa a diferença entre a carga neutralizada peìa camada de Stern. Logo, o potencial zeta representa a carga efetiva das part $\bar{i}$ 
culas ou potencial da camada difusa ou de GoY. Quando um lí quido contendo partículas com carga è colocado em campo elētrico, as partículas carregadas positivamente são atraídas para catodo $(+1$ e as partículas negativas para o anodo $(-)$. A atração é aumentada conforme a intensidade da carga das par tîculas. A velocidade da mobilidade das particulas em um da do campo elétrico aumenta com o potencial zeta da partícula. o valor do potencial zeta será elevado, quando a densidade de carga for alta e quando for grande a força eletrostática de repulsão, a qual mantém as partículas separadas (80). Segun do Martin (68), a adição de ions da carga oposta à das partị culas em suspensão reduz a intensidade de carga e o potencial zeta diminui e, consequentemente, a suspensão apresenta o mā ximo de floculação. Porēm, um excesso de ions poderä inverter a carga das particulas, aumentando o potencial zeta e di minuindo a floculação. Uma outra maneira de controlar a flo culação é através do uso de polīmeros hidrōfilos, que formam uma camada protetora ao redor das partículas. Estes polímeros se associam fracamente em flocos soltos, evitando-se o fé nōmeno da compactação (97).

\section{3 Formulação}

As suspensões farmacēuticas são sistemas complexos, não permitindo estabelecer regra universal no tocante ao desenvolvimento farmacotécnico. Na formulação de tais sistemas devem ser considerados fatores físico-quimicos, que influenciam na estabilidade do produto, visando a eficácia terapêtica durante o prazo de validade do mesmo.

A fórmula bāsica de suspensão consiste do fármaco, agente molhante, agente suspensor, edulcorante e conservante. 
Pode haver inclusão de outros componentes como flavorizante, corante e sistema-tampão $(97,98)$.

Os tensoativos são agentes molhantes principais e di versos estudos foram desenvolvidos com este tipo de adjuvan te farmacotécnico com vistas à estabilidade de suspensão ( 7 , 28, 109). Classificam-se em iōnicos e não iōnicos. Dentre os primeiros, os aniónicos e os catiōnicos são mais eficientes para fármacos com potencial zeta negativo e o positivo, respectivamente (91). Entretanto, os não iōnicos são mais utilizados em função da baixa energia de adsorçăo e com isto não propiciam a formação de espēcie iônica (46). Os derivados do sorbitan são mais amplamente utilizados (62). Para que os tensoativos apresentem caracteristicas molhantes adequadas, os valores de EHL sugeridos devem estar entre 6 e 9 $(87,97)$.

Consideram-se, tambēm, como agentes molhantes, algumas substâncias hidrófịlas, constituídas por macromoléculas hidrōfilas e compostos hidrófilos insolūveis em àgua. Enqua dram-se entre estes, a glicerina, sorbitol, carboximetilcelu从 lose sōdica, bentonita, Veegum ${ }^{R}$, hidrōxido de alumínio e ou$\operatorname{tros}(26,58,86)$.

Os agentes suspensores são utilizados para aumentar a viscosidade da fase contínua das suspensões farmacêuticas. Isto se deve as alto grau de hidratação dos mesmos, pois apre sentam a capacidade de ligação hïdrica dentro das cadeias ma cromoleculares entrelaçadas. Há, como resultado, o encobrimento das partículas diminuindo ou impedindo a interação entre as particulas e a fase continua (99l. Segundo scheER( 97 ), - agente suspensor ideal deve produzir a estrutura do veículo, 
ter alta viscosidade para manter as partīculas em suspensão durante o armazenamento e ter baixa viscosidade durante a agitação e uso do produto.

Encontram-se na literatura vārias maneiras de class $\underline{i}$ ficar os agentes suspensores $(26,31,50,87,97,99)$. Segun do IDSON e BACHYNSK (50), estes compostos podem ser subdivididos em gomas e argilas, que podem ter origem natural, semisintētica e sintētica.

Entre os agentes suspensores bastante empregados, en contra-se a carboximetilcelulose sódica. Devido às suas pro priedades, è tambēm usada como estabilizante, emulsificante e desagregante em outras formas farmacéuticas (22). Apresenta emprego terapéuticn como laxativo, no tratamento da hiperaci dez gāstrica e na obesidade (2E). Alēm disto, è utilizada em fórmulas cosméticas $(39,44)$ e em alimentos (20). E atōxica e não irritante em soluções orais a $2 \%$. Trata-se de excipien te adequado para suspender substāncias insolūveis por longo tempo (37). Este composto foi largamente estudado como agen te suspensor por diversos pesquisadores $(23,44,51,53,58$, 53, 108). As suspensões de carboximetilcelulose sōdica são estāveis em pH entre 4 e 11. Por isso, são compatíveis com grande nümero de färmacos (23), 64, 99). Entretanto, a carboximetilcelulose sódica, por ser de natureza aniōnica, apre senta incompatibilidades com sais de ferro, aluminio e chumb.o $(50,86)$. E tambëm compatível com propilenoglicol, glice rina, sorbitol e com polissorbatos 20 e 80 . E rapidamente hi dratada com āgua quente, sob suave agitação. Esta proprieda de é, ainda, favorecida quando na presença de ālcool, gliceri na ou polissorbato (40). A caracteristica reológica deste 
agente suspensor è do tipo pseudo-plästica $(43,100)$. Quando sob agitação vigorosa por um prolongado perỉodo de tempo, apresenta característica tixotrópica, propriedade esta desejāvel, fato que não ê facilmente alcançado pela metilcelulose (99). Associações com outros agentes suspensores têm sido propostas com a finalidade de investigar o sinergismo reo 1ógico $(19,107)$. Quando em mistura com Veegum ${ }^{R} H V$ em partes iguais, apresenta características pseudo-plástica e tixo trōpica $(100)$.

o veegum ${ }^{R}$ é um silicato de aluminio e magnésio, produto de origem natural, pertencente ao grupo de montmorrilonita (78). Apresenta muitas propriedades comuns à bentonita, porēm, oferece vantagens sobre ela (2).

Existem värios tipos de Veegum ${ }^{R}$ comercializados com siglas R, K e HV. Os dois primeiros são estāveis em pH ācido e o tipo HV apresenta alta viscosidade em relação aos outros. Todos são atóxicos e podem ser utilizados por via interna ou externa. As suspensões coloidais de veegum ${ }^{R}$ são in sîpidas, inodoras e possuem pH alcalino de aproximadamente 9,6; entretanto, são eficazes como agente suspensor em produtos com valores de pH variando de 5 a $11(50)$. O Veegum é compativel com altos teores de solventes orgänicos, misciveis em àgua. Para se preparar dispersão de Veegum ${ }^{R_{H V}}$ a $1 \%$, o $\overline{1}$ cool deverá ser, no máximo, $60 \%$, enquanto que, a $2 \%$ o teor alcoólico da mistura não deverā ultrapassar a 40\%. Da mesma maneira, pode-se juntar a glicerina, propilenoglicol, polietilenoglicol $(69,75)$ e sorbitol. A mistura de Veegum HV e sorbitol em proporção igual pode ser empregada como adjuvante farmacotēcnico alternativo de goma adragante (32). 
Estes agentes são hịdratados à semelhança da carboxi metilcelulose sôdica, adicionando-se pequenas quantidades, sob agitação, em àgua fria ou quente. A incorporação de vee gum $^{R}$ em āgua quente acelera a dispersão e, assim, resulta so lução coloidal de alta viscosidade $(17,50,78)$. Outros com ponentes não devem ser adicionados até que este agente seja totalmente disperso; caso contrārio, hā diminuição da viscosidade (99). As suspensões contendo veegum ${ }^{R}$ são tixotröpicas $(38,50,64,87)$.

A lēm da associação do veegum ${ }^{R}$ com carboximetilcelulo se sōdica, outros agentes suspensores têm sido propostos na formulação de suspensão $(19,31,75,101,106)$.

o glicolato de amido sódico è um sal sōdico de éter carboxílico de amido. E obtido atravēs de eterificação parcial dos trēs grupos hidroxîlicos presentes em cada anel glu copiranōsido da molécula polimétrica de amido natural.

No mercado brasileiro é conhecido com o nome de Vis$\operatorname{cosol}]^{R}$. Dois tipos de $V$ iscosol ${ }^{R}$ são usados como agentes sus pensores: o tipo IV, para suspensões farmacẽuticas extemporâa neas; e o tipo RV para suspensões clässicas $(31,101)$. Alēm deste uso, encontra aplicação como agente aglutinante e desa gregante em comprimido $(6,60,73)$.

o glicolato de âmido sódico é facilmente disperso em água aquecida, quando auxiliada com agitação. Na concentração de $2 \%$ apresenta o pH entre 5,5 e 7,5 (101). Sua caracte rīstica reológica é do tipo pseudo-plāstico e levemente tixo tröpica (94).

A maioria das suspensões requer edulcorantes para 
mascarar o sabor desagradāvel dos färmacos. Os edulcorantes são classificados em naturais, semi-sintēticos e sintēticos $(50,99)$. A sacarose, entre os naturais, é mais utilizada, pois, o xarope simples contendo $85 \%$ de $p / v$ de sacarose serve como veículo de numerosos färmacos (22). 0 mel e a glicose são também usados, mas nenhum dos edulcorantes naturais pode ser utilizado por diabēticos. Os semi-sintéticos, representados pelos ālcoois poli-hỉdricos, são edulcorantes ra zoāveis e tambēm servem como solventes e estabilizantes no sistema de suspensão. Como exemplo tem-se a glicerina, que também pode apresentar caracterīsticas molhantes; o manitol e o sorbitol $(52,87)$. Quando o produto apresenta pH acima de 5 , prefere-se o sorbitol à sacarose. A sacarina sódica e - ciclamato de sódio podem apresentar concentrações de 0,05 a $0,5 \%$ com intuito de conseguir dulçor desejāvel (99).

A conservação de suspensões apresenta algumas dificuldades. Os conservantes mais comuns são os parabenos, āc do benzóico e seu sal sódico, clorobutanol e compostos de amónio quaternārio. Estes compostos interagem com as macro molēculas, naturais ou sintēticas presentes na formulação. Esta interação pode levar à diminuição ou eliminação da con centração livre dos conservantes, conduzindo à ineficācia a timicrobiana. A interação com alguns agentes suspensores tem sido objeto de estudo de vārios pesquisadores $(21,66$, 74, 111). Quanto aos tensoativos, existem muitos trabalhos procurando esclarecer os mecanismos envolvidos e o cálculo das concentrações de conservantes necessārios $(3,4,30,57$, 83, 85). Porēm, suspensões são sistemas heterogẽneos, que necessitam de comprovação experimental da eficácia antimicro biana dos conservantes (42, 95, 103). 
3 OBJETIVO

A formulação de medicamento, de modo geral, implica em estudos de compatibilizafão entre os insumos, com vistas à obtenção de formas farmacēuticas estäveis. Apesar disto, pode-se encontrar especialidades com problemas, não só comprometendo a sua apresentação, mas envotvendo a eficācia e segurança terapēuticas.

Pode ser verificada nas suspensões contendo eritromicina, na forma de estearato, de procedencia nacional, a inconveniēncia que reside na elevada viscosidade ou na flutuação do fārmaco. No primeiro caso nota-se dificuldade em verter o lĩquido para colher-medida, apesar da aparente homogeneidade do sistema. No outro caso: pode ocorrer redispersão demorada ou incompleta, comprometendo a uniformidade da dose a ser administrada, o esquema pcsológico e a eficācia terapéutica.

o objetivo do presente trabalho consistiu em estu dar diferentes adjuvantes farmacotécnicos, a fim de verificar fatores interferentes que podem melhorar a estabilidade da suspensão de estearato de eritromicina. 
4 MATERIAIS E. METODOS

4.1 Materiais

4.1.1 Matērias-primas

As matērias-primas utilizadas na preparação das suspensões estäo relacionadas, a seguir, conforme a especificação e fornecedor.

- ācido benzóico, Farm.Bras.III, Henrifarma Produtos Químicos Farmacêuticos Ltda;

- ā1cool etîlico, Farm.Bras.II, Álcool Ferreira S/A;

- carboximetilceiulose södica (Boniaso1 ${ }^{R}$ 2.600), Farm.Bras. II I, Companhia Brasileira de Produtos Químicos Bonomia;

- estearato de eritromicina, B.P.C. 1980, Abbot Laborarórios do Brasi1;

- glicerina, Farm.Bras.III, Polyfarma S/A Com. Ind. de Produtos Químicos e Farmacêuticos;

- glicolato de amido sōdico (Viscosol'R R.V), USP.XX - N.F.XV, Trinca Indūstria e Comērcio Ltda;

- metilparabeno, Farm.Bras.III, Merck;

- monoestearato de sorbitan (Span 60) B.P.C. 1980, Atlas Indūstrias Quīmicas S/A;

- monoestearato de sorbitan etoxilado (Polissorbato 60) B.P.C. 1980, EUA, Atlas Indústrias Químicas S/A;

- molooleato de sorbitan (Span 80), B.P.C. 1980, EUA, Atlas. Indústrias Quĩmicas $S / A$;

- monooleato de sorbitan etoxilado (Polissorbato 80), Farm. Bras. III, Brasil, Atlas Indūstrias Quĩmicas $S / A$;

- propilparabeno, Farm. Bras. II, Alemanha, Merck; 
- sacarina sōdica, Farm.Bras.KK, Henrifarma Produtos Químicos e Farmacéuticos Ltda;

- sacarose, Farm.Bras.II, Companhia União dos Refinadores de Açūcar e Café;

- silicato de alumỉnio e magnésio (Veegum ${ }^{R} H V$ ), Vanderbeeld;

- sorbitot, U.S.P. XX - N.F. XV, Avon Cosméticos Ltda.

\subsubsection{Equipamentos}

- agitador mecānico Fanem, Contrac Modelo 100, com velocidade regulāve1;

- agitador mecānico fisaton, Mode10 710, com velocidade regu 1āve 1 ;

- agitador c-rotativa, Fanem, Modelo Kline, com velocidadere gurāve 1 ;

- balança industrial, Filizola, com capacidade para 5 quilos;

- balança analitica, E. Metler;

- balança semi-analítica, E. Metler;

- banho-maria BÜCHI, Modelo W

- densímetro, INCONTERM, 20 OQC;

- conjunto de tamises, Granutest;

- espectrofotómetro Varian, mode10 634;

- fogareiro a gás com duas bocas;

- homogeneizador, Meteor, modelo Rex-1;

- microscópio bi-ocular, Reichert;

- potenciómetro, Beckman, modelo Zeromatic;

- recipiente de aço inoxidável com capacidade para 1,0; 1,7; 5,0 e 10 1itros;

- viscosimetro rotacional Brookfie1d, mode10 RVT. 


\subsection{Métodos}

4.2.1 Estudo de alguns adjuvantes farmacotécnicos utilizados na formulação de suspensões.

\subsubsection{Influência dos tensoativos.}

Foram preparadas, em provetas de $25 \mathrm{~mL}$, diversas as sociações de Polissorbato 60 e Span 60 , de modo a obter os seguintes valores de EHL: 6, 7, 8, 9, 10, 11, 12, 13 e 14 . Para isto, baseou-se na proporção constante da Tabela I (pá gina 31 ).

A partir de cada par de tensoativos foram preparados $25 \mathrm{~mL}$ da solução aquosa a $3 \%(p / v)$ com àgua destilada. A se guir foi vertido, cuidadosamente, $1,0 \mathrm{~g}$ de estearato de eritromicina na superfície do líquido e a observação visual da molhabilidade do pó foi efetuada com 1 e 3 horas após a adição do pó à solução de tensoativos. Apōs segunda observação, - conteúdo de cada proveta foi agitado manualmente, por inversão, até perfeita homogeneização e foi deixado em repouso durante uma semana à temperatura ambiente, quando foi efetuada nova observação macroscópica do aspecto da mistura. Foi verificada, tambēm, a redispersabilidade das suspensões, mediante agitação manual das provetas, por inversão.

0 mesmo procedimento foi efetuado com o par de Polis sorbato 80 e Span 80 , ajustando-se os valores de EHL. para 10, $11,12,13$ e 14, segundo a relação constante da Tabela I.

\subsubsection{Influência dos edulcorantes}

Os edulcorantes estudados foram a sacarose, glicerina e sorbitol a 70\%. As concentraçōes testadas, para cada 
TABELA I. - VALORES DE EHL E PROPORÇOES DE TENSOATIVOS

\begin{tabular}{|c|c|c|c|}
\hline EHL & $\begin{array}{c}\text { Span } 60 \text { - Polissorbato } 60 \\
\text { (g) }\end{array}$ & $\begin{array}{l}\text { Span } 80-P \\
(g)\end{array}$ & $\begin{array}{c}\text { Polissorbato } 80 \\
\text { (g) }\end{array}$ \\
\hline 6 & $87,2: 12,8$ & & - \\
\hline 7 & $77,4: 22,6$ & & - \\
\hline 8 & $67,6: 32,4$ & & - \\
\hline 9 & $57,8: 42,2$ & & - \\
\hline 10 & $48,0: 52,0$ & 46,7 & $: 53,3$ \\
\hline 11 & $38,2: 61,8$ & 37,6 & : 62,4 \\
\hline 12 & $28,4: 71,6$ & 28,0 & $: 72,0$ \\
\hline 13 & $18,6: 81,4$ & 18,7 & $: 81,3$ \\
\hline 14 & $8,8: 91,2$ & 9,6 & $: 90,4$ \\
\hline
\end{tabular}


edulcorante: foram $10,20,30,40$ e $50 \%(p / v)$ em àgua destila da .

Foram preparados $500 \mathrm{~mL}$ de cada solução, as quais fó ram analisadas quanto ao pH, à densidade e viscosidade.

Para cada copo graduado de $250 \mathrm{~mL}$ foram transferidos $200 \mathrm{~mL}$ dos veículos anteriormente preparados. A dispersão de $10,0 \mathrm{~g}$ de estearato de eritromicina em cada veículo foi mediante adição gradativa do mesmo, auxiliando-se a homogeneização com agitador mecānico Fanem, Contrac modelo 100, com 300 rpm. Apōs a adição total do fārmaco, continuou-se a agi tação por mais 5 minutos. Completou-se o volume para $250 \mathrm{~mL}$, com o veículo correspondente e homogeneizou-se, manualmente, com bastão de vidro.

Cada suspensão foi transferida para 2 provetas gradu adas de $100 \mathrm{~mL}$, com rolha esmerilhada. Após inversão manual das provetas por 4 vezes, de 1800 , as mesmas foram mantidas em repouso. No decorrer do tempo foram efetuadas leituras do volume ocupado pelo fármaco. Estas observações foram de 15 em 15 minutos, nas duas primeiras horas, de hora em hora durante as 12 horas e, diariamente, atē completar uma semana.

\subsubsection{Influēncia dos agentes suspensores.}

Os agentes suspensores testados foram a carboximeti 1 celulose södica (Boniasol $\left.{ }^{R} 2.600\right)$, silicato de aluminio e mag nësio (Veegum ${ }^{R} H V$ ) e glicolato e amido sódico (Viscosol ${ }^{R} V^{\prime}$ ). Para cada agente suspensor as concentrações foram de 0,3;0,6; 0,$9 ; 1,2$ e $1,5 \%(p / v)$ em àgua desti1ada. Prepararam-se 500mL de cada uma, utilizando-se o seguinte procedimento: em recipi 
ente de aço inoxidāivel de $1000 \mathrm{~mL}$ foram transferidos $200 \mathrm{~g}$ de āgua destilada, a qual foi aquecida a 80-85 ọ, em banho-maria, dispersando-se o pó, aos poucos, com auxỉlio de agitador Fanem e aproximadamente $200 \mathrm{rpm}$. Continuou-se a agitação por 15 minutos e a suspensão foi resfriada naturalmente até a tem peratura ambiente. 0 peso foi ajustado pela adição de àgua destilada, para $200 \mathrm{~g}$, e a dispersão permaneceu em repouso du rante 20 horas. A seguir, verteu-se o conteūdo para copo de vidro graduado e completou-se o volume para $500 \mathrm{~mL}$, com àgua destilada, seguindo-se de agitação durante 5 minutos, nas mes mas condições anteriormente descritas. Em cada dispersão foram determinados $\mathrm{pH}$, densidade e viscosidade.

As suspensões de estearato de eritromicina, a $4 \%$ ( $p / v)$, foram preparadas empregando-se cada dispersão dos 3 agentes suspensores separadamente, segundo a técnica descrita no item 4.2.1.2. O acompanhamento do comportamento destas suspensões, com determinação do volume do sōlido e do veĩculo, seguirảm o mesmo esquema descrito no item 4.2.1.2.

4.2.2 Estudo de estabilidade das suspensões de estea rato de eritromicina.

4.2.2.1 Estudo prēvio.

4.2.2.1.1 Förmula das suspensões.

As suspensões foram preparadas segundo as fórmulas constantes da Tabela II ( 1 a 6). (pägina 39), no volume de 100 $\mathrm{mL}$ cada. As 6 preparações iniciais variaram na concentração do par de tensoativos, mantendo-se o valor de EHL em 13. 
outras suspensões foram preparadas mantendo-se o par de tensoativos a $1 \%$, porēm, houve variação no teor de agentes suspensores, alēm de adição de conservantes. Foram preparados $500 \mathrm{~mL}$ de cada uma das suspensões, conforme a Tabela II e Tabela II (suspensões de nümeros 7 a 15), (páginas 39 e 40). As suspensões de números 16 a 24, conforme a Tabela II (pāgina 40), foram obtidas utilizando-se o par de tensoa tivos Polissorbato 80 - Span 80 , na concentração de $3 \%$ (p/v), em EHL 13.

Cada suspensäo, diferindo entre si em, pelo menos, uma caracteristica qualitativa ou quantitativa, foi mantida em proveta graduada de $100 \mathrm{~mL}$, à temperatura ambiente. A obser vação do comportamento das mesmas foi conforme o item 4.2.1.2.

\subsection{Técnica de preparação}

4.2.2.1.2.1 Preparação do meio suspensor

Foi aquecido em banho-maria, a 80-85 ọ, o recipiente de aço inoxidāvel de $1000 \mathrm{~mL}$ contendo $100 \mathrm{~g}$ de àgua desti 1ada. Foram adicionados $15 \mathrm{~g}$ de carboximetilcelulose sódica e a homogeneização da dispersão foi obtida pela agitação, dü rante 15 minutos, com agitador Fisaton, com $250 \mathrm{rpm}$. A dispersão foi resfriadâ, naturalmente, atē a temperatura ambien te e foi mantida em repouso durante 20 horas. Decorrido este tempo, o peso do material foi ajustado para $100 \mathrm{~g}$ com água destilada e submetido à agitação por 5 minutos, em condições idênticas às do dia anterior. A seguir, adicionaram-se 390 $g(300 \mathrm{~mL})$ de xarope recém-preparado, contendo 3 conservantes. Esta mistura foi fervida durante 10 minutos, mantendo- 
se a agitação mecānica. Apōs esfriamento em banho de àgua fria, o peso foi ajustado para $500 \mathrm{~g}$, com àgua destilada. Es te procedimento foi adotado na obtenção dos 18 meios suspensores, correspondentes às förmulas 7 a 24 das Tabelas II e II I .

4.2.2.1.2.2 Dispersão de estearato de eritromicina.

Foram pesados, em bequer de $250 \mathrm{~mL}, 15 \mathrm{~g}$ do par Po1issorbato 80 - Span 80 , em EHL 13, segundo a Tabela I. Foram adicionados $50 \mathrm{~g}$ de àgua destilada e a mistura foi aquecida em banho-maria a 50-60 ọc, acompanhada de homogeneização com agitador Fanem, a aproximadamente $250 \mathrm{rpm}$, durante $10 \mathrm{mi}$ nutos. 0 produto foi resfriado naturalmente, atē temperatura ambiente. Foram dispersos, aos poucos, $20 \mathrm{~g}$ de estearato de eritromicina na mistura anterior, com agitação mecānica durante 5 minutos, em condição idēntica à anterior.

\subsection{Preparação da suspensão.}

Foram transferidos para copo graduado de $500 \mathrm{~mL}$, a dispersão do färmaco e $500 \mathrm{~g}$ do meio suspensor, preparados conforme a técnica descrita nos itens 4.2.2.1.2.1 e 4.2.2.1.2.2. Após completar o volume para $500 \mathrm{~mL}$, com àgua destilada, a mistura foi homogeneizada com agitador Fanem, a 300 rpm, durante 5 minutos. Finalmente, a preparação foi passada pelo homogeneizador durante 30 segundos, seguida de recolhimento da suspensão em copo graduado de $500 \mathrm{~mL}$. o produto permane- 
ceu em repouso durante 48 horas, à temperatura ambiente, quan do foi novamente agitado com auxĩlio de bastão de vidro. o mesmo foi submetido à determinação de $\mathrm{pH}$, densidade e viscosidade.

o acompanhamento da estabilidade física desta suspensão foi apōs transferēncia da mesma para 2 provetas de 100 $\mathrm{mL}$ e 3 frascos de vidro àmbar, com capacidade de $100 \mathrm{~mL}$. Es tes foram mantidos à temperatura ambiente, em posição estáti ca, anotando-se o volume do färmaco disperso e a caracterīstica quanto à flutuação ou sedimentação do pō. Estas observações foram efetuadas diariamente, durante 15 dias.

As suspensões de nọ 1 a 6 foram preparadas com a mes ma tēcnica, exceto a agitação que foi manual, com bastão de vidro, eliminando-se a fase de tratamento em homogeneizador.

4.2.2.2 Estudo definitivo das suspensöes.

4.2.2.2.1 Fórmulas das suspensões.

Foram preparadas 24 suspensões, de nọ 25 a 48, da Tabela IV, (página 41), utilizando-se como edulcorante a gli cerina e o sorbitol a $70 \%$ na proporção de $10,20,25,30$ e $35 \%(p / v)$, conforme o agente suspensor. As concentrações de Boniasol 2.600 foram de $1,0,1,1$ e $1,2 \%(p / v)$; as de Veegum HV foram $1,2,1,2$ e $1,5 \%(p / v)$ e $1,2 \%(p / v)$ de Viscosol RV.

A inclusão de sacarina sōdica foi constante em todas as preparações, na concentração de $0,4 \%$ ( $p / v)$. 
Span 80 , na concentração de $3 \%(p / v)$ em EHL 13, conforme a Tabela I (pāgina 31).

Os 3 conservantes foram incluídos em todas as fórmulas, tendo sido previamente solubilizados em quantidade suficiente de etanol.

As suspensões de nọs 25 a 30 , conforme as fórmulas da Tabela IV (pāgina 41), foram obtidas fixando-se em. 35\% $(p / v)$ o teor de edulcorante e $1,2 \%(p / v)$ o de agente suspen sor.

As suspensões de nọs 31 a 36, da Tabela IV (pāgina 41), apresentaram diferenças no teor de edulcorante, fixado em $30 \%(p / v)$.

Outras preparações contendo Boniasol 2.600 ou Veegum HV tambēm continham $30 \%(p / v)$ de edulcorante, enquanto que naqueles casos contendo Viscosol RV foi de $25,20,10 \%$ $(p / v)$. Estas suspensões, de nümeros 37 a 42 continham $1,1 \%$ (p/v) de Boniasol 2.600, 1,4\% e 1,5\% (p/v) de Veegum HV e $1,2 \%(p / v)$ de Viscosol RV.

Apōs a avaliação visual e física destas preparações, durante 45 dias, procedeu-se à preparação de outras 6 suspen sões, de número 43 a 48 , conforme as fórmulas da Tabela $V$ (pāgina 42).

4.2.2.2.2 Técnica de preparação.

Para a preparação das suspensōes de nọs 25 a 48, a técnica utilizada foi semelhante $\bar{a}$ descrita no item 4.2.2. 1.2. 
Nas suspensões que continham a carboximetilcelulose sódica e o glicolato de amido sódico, como agentes suspenso res, a dispersão foi efetuada sobre o agente edulcorante. Adicionou-se, posteriormente, a àgua destilada e submeteu-se a mistura ao aquecimento. 0 volume utilizado de àgua desti lada foi de $200 \mathrm{~mL}$ para todos os meios suspensores.

As determinações de $p H$, densidade e viscosidade e doseamento do färmaco foram efetuadas no in îcio da formulação, bem como apōs 30 semanas de observação das suspensões. o acompanhamento da leitura do volume do fármaco disperso foi feito diariamente, durante a primeira semana e: posteriormente, com intervalo de 7 dias, durante 30 semanas. 0 aspecto da suspensão e a caracterīstica de ressuspensão foram determinados após 30 semanas de observação. 


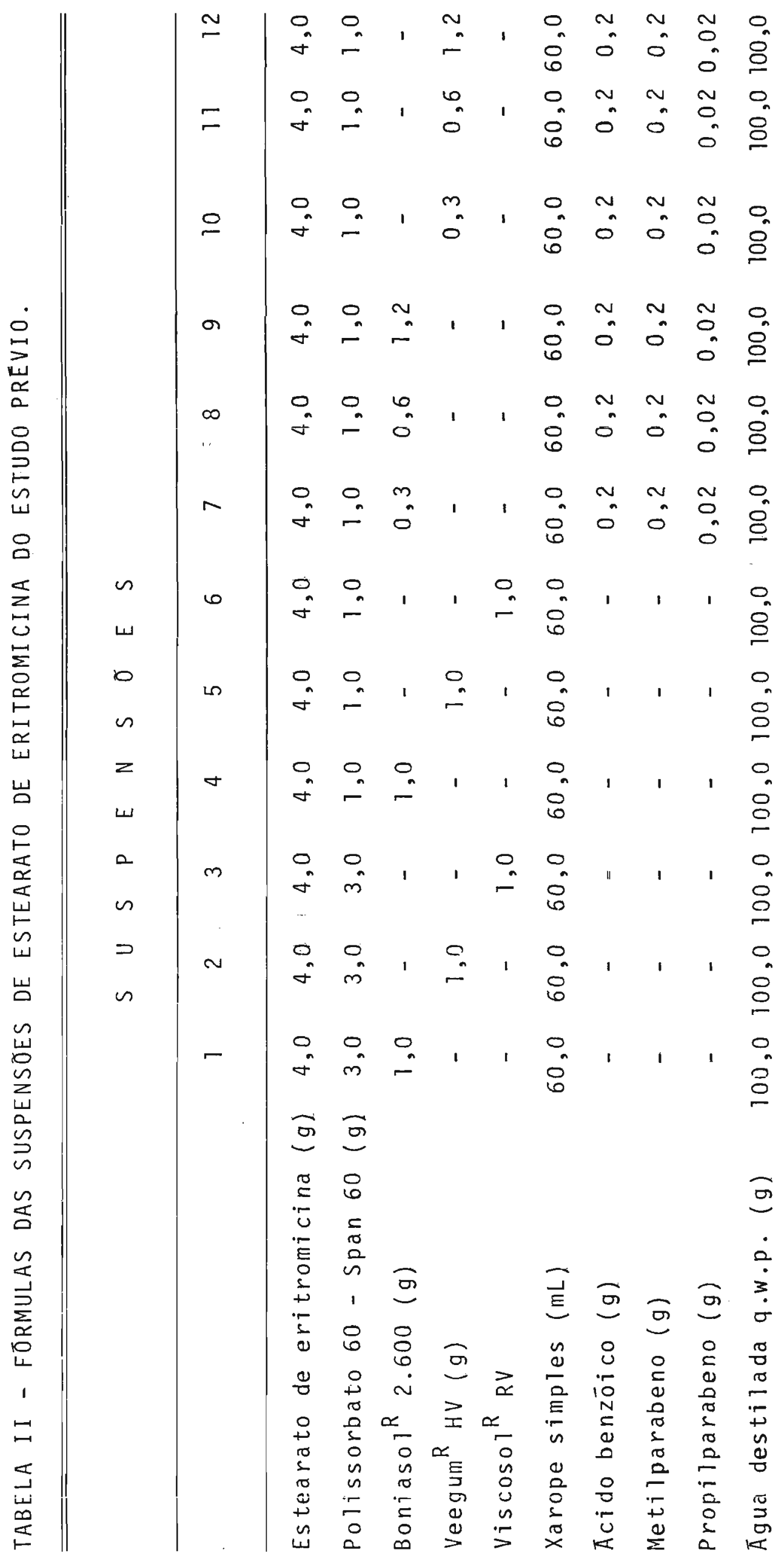


要

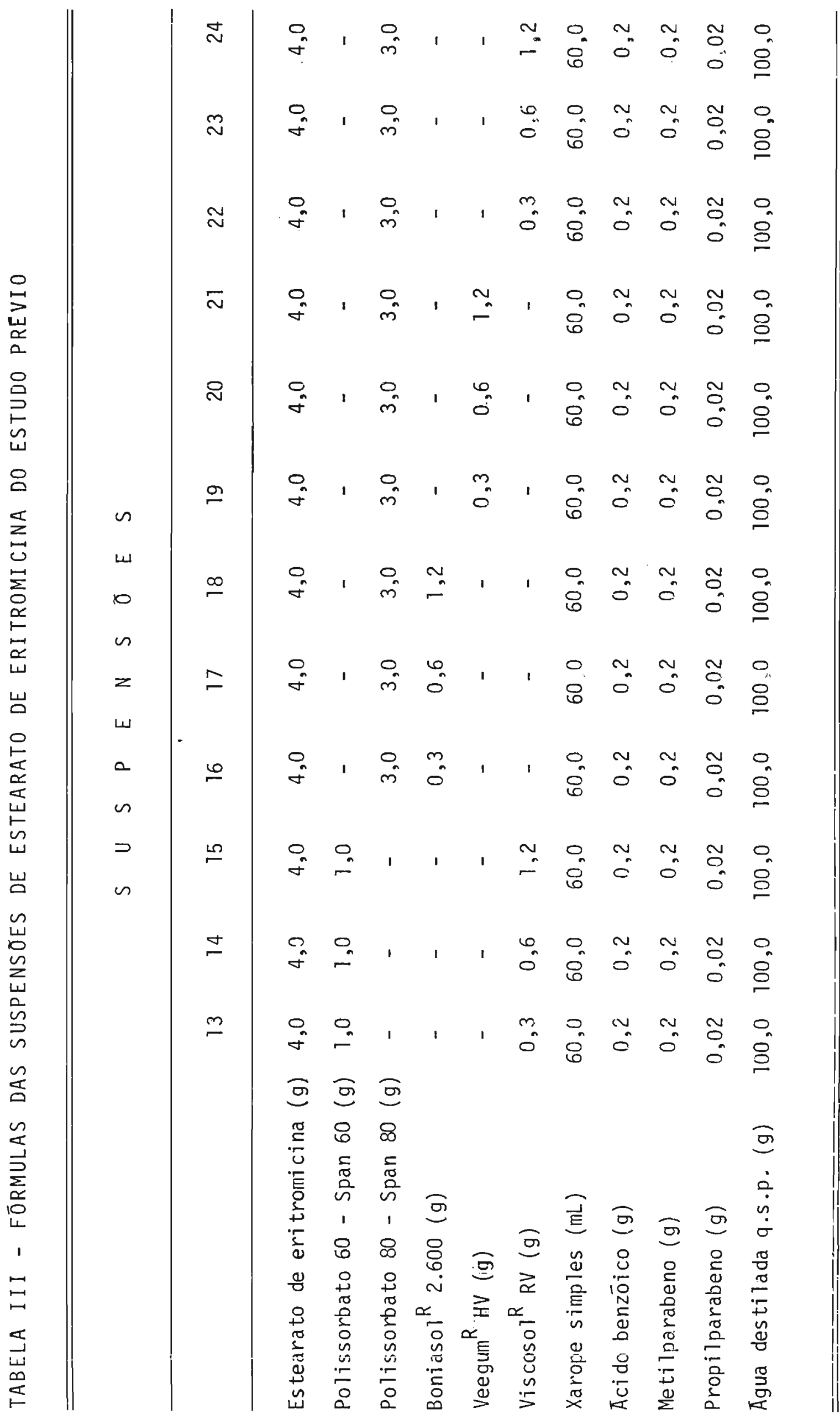




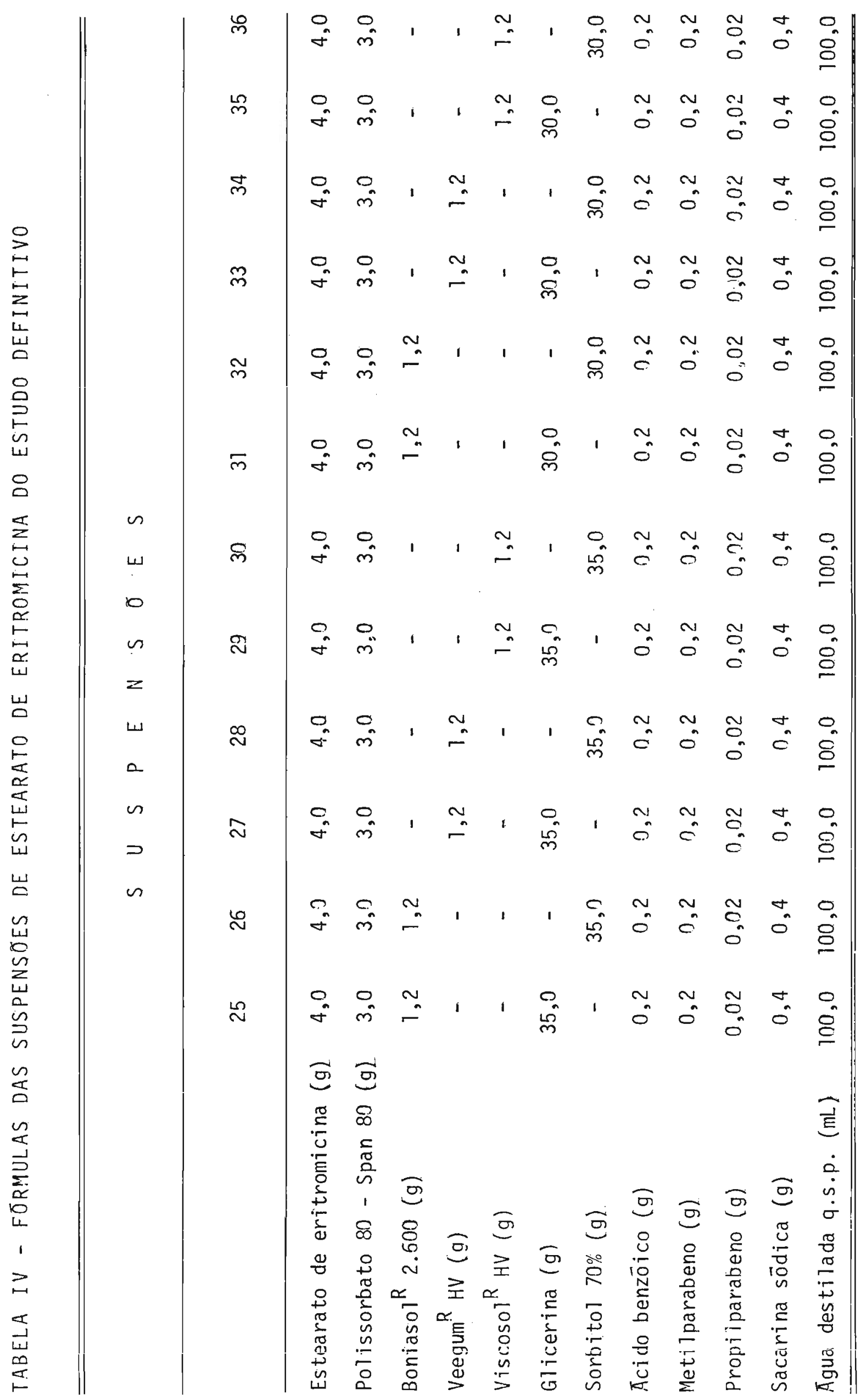




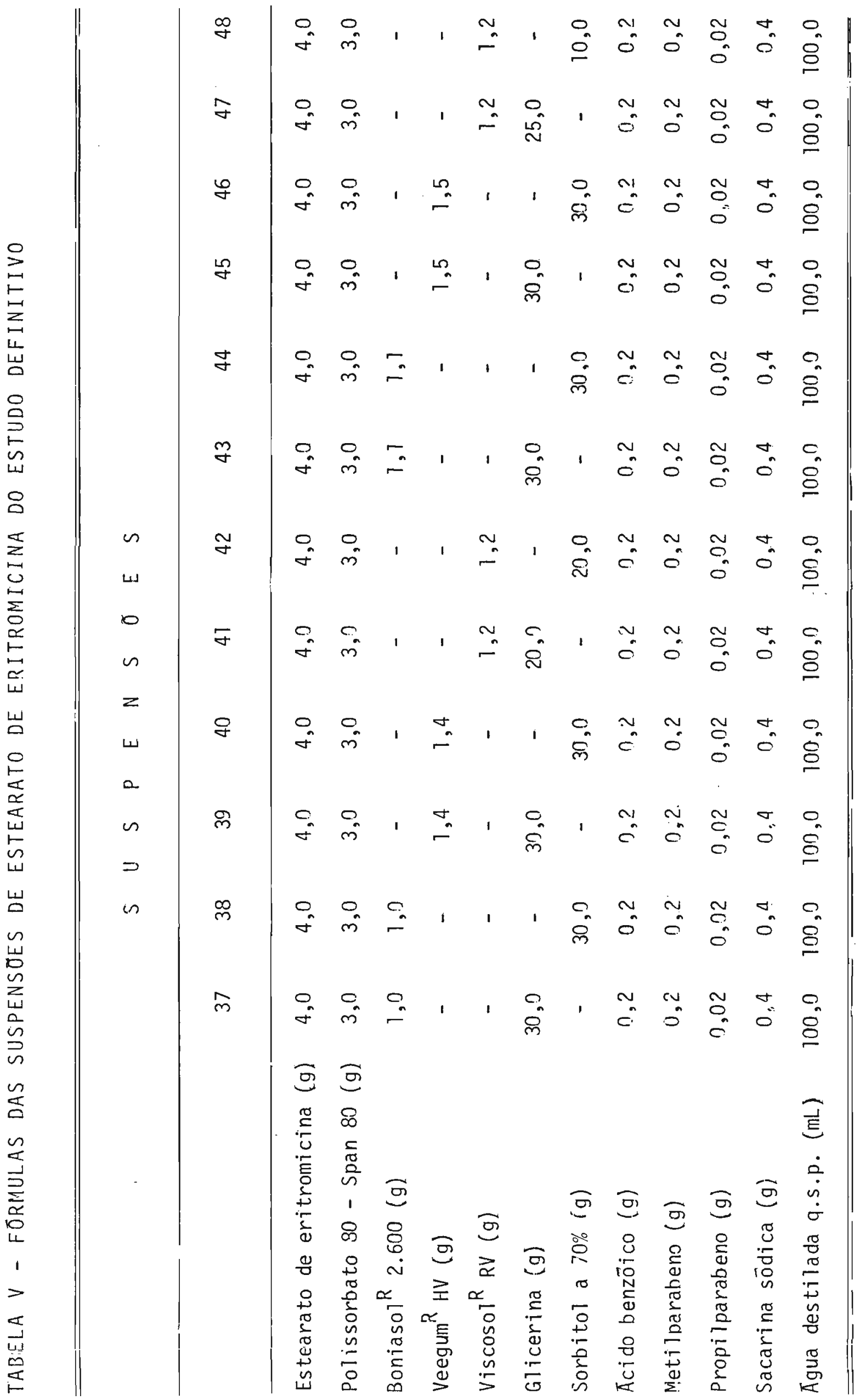




\subsection{Determinação de Parâmetros Analîticos}

\subsubsection{Tamanho de particulas}

A determinação do tamanho de partículas de estearato de eritromicina foi efetuada com auxîlio do microscópio, acoplando-se ocular micrométrica, com aumento de 1250 vezes.

Analisou-se o pó em forma de suspensão aquosa, na concentração de $0,2 \%(67,87,90)$. Foram efetuadas contagens em campos microscópicos e o resultado foi a média aritmética destes valores.

\subsubsection{Volume e densidade aparentes}

o volume aparente foi determinado em copo graduado, de $125 \mathrm{~mL}$, em forma de sino. Foram transferidos $50 \mathrm{~g}$ de estearato de eritromicina. O recipiente foi submetido à queda livre, de altura de 2 a $3 \mathrm{~cm}$, sobre a superfície coberta de borracha. Esta operação foi manual, repetindo-se a queda por 200 vezes, com intervalo de 2 a 3 segundos entre as operações. 0 volume do pó foi determinado pela leitura após a compactação $(87,105)$. O valor de volume aparente do antibiótico foi obtido pela média das 10 determinações.

A densidade aparente foi calculada dividindo-se o peso da substāncia pelo respectivo valor de volume obtido.

$$
4.3 .3 \mathrm{pH}
$$

A determinação dos valores de pH foi efetuada em po tenciometro, à temperatura de 25 ọC. Para isto, utilizaram- 
se cerca de $10 \mathrm{~mL}$ de amostra previamente homogeneizada (33).

\subsubsection{Densidade}

A densidade das dispersões foi determinada em prove ta graduada de $250 \mathrm{~mL}$, contendo cerca de $250 \mathrm{~mL}$ da amostra, a $20 \pm 190$, empregando-se o densimetro (65).

\subsubsection{Viscosidade}

A viscosidade aparente foi determinada em viscosime tro rotacional. A amostra foi colocada em bequer de $500 \mathrm{~mL}$, controlando-se a temperatura para 20 OC, sendo submetidos aos graus de cisalhamento 20,50 e $100 \mathrm{rpm}(93,107)$.

\subsubsection{Aspecto da suspensão}

As amostras de suspensão foram submetidas à observa ção macroscōpica, verificando-se o tipo de comportamento da dispersão. Foram classificadas em tipo "com flutuação" e "com sedimentação" (S). O primeiro tipo foi subdividido em compactado (FC) e sem compactação (FS); o segundo tipo: foi, por sua vez, subdividido em compactado (SC) e sem compactação (SS). A fração lĩquida separada foi classificada em função do grau de turbidez: em turvo (Tu) e limpido (Li).

\subsubsection{Volume do färmaco disperso}

As suspensões acondicionadas em proveta de $100 \mathrm{~mL}$, mantidas em repouso à temperatura ambiente, serviram para de 
terminação do volume ocupado peto färmaco disperso (Vs). Em função da posição das partículas do fármaco em suspensão, ado tou-se classificação como volume de partículas sedimentadas, (Vs) e volume de particulas flutuantes (Vf). Calculou-se o volume de sedimento pela relação Vs/Vo, sendo Vo o volume to tal da suspensão (104). Da mesma forma, pela relação $V f / V o$, determinou-se o valor de volume do flutuado.

\subsubsection{Característica de ressuspensão}

Para determinar a propriedade de re-homogeneização das suspensões, foram utilizadas amostras acondicionadas em frascos de vidro de $100 \mathrm{~mL}$. Os mesmos foram submetidos à ho mogeneização no agitador rotativo. Foram aplicados cerca de 250 rpm, anotando-se o tempo necessärio, em segundos ou minu tos, para a homogeneização do conteūdo.

Com amostras acondicionadas em provetas de $100 \mathrm{~mL}$, a característica de ressuspensão foi determinada mediante in versão manual da mesma de 180 ․ A classificação da mesma foi de acordo com o número de inversões necessārias para a completa homogeneização da suspensão, considerando-se fäcil (Fa), quando exigia de 1 a 5 vezes; regular (Re), de 6 a 10

vezes e difícil (Di), quando exigia inversão maior que 11 ve zes.

\subsubsection{Doseamento do antibiótico}

A determinação de teor de eritromicina na matēriaprima e nas suspensões; no decorrer do armazenamento destas, baseou-se na reação colorimétrica com xantidrol (49). 
A preparação da solução-padrão foi realizada median te a pesagem de, exatamente, $125 \mathrm{mg}$ de padrão de eritromicina base: com teor de $95,5 \%$. Esta tomada foi transferida quan titativamente para balão volumētrico de $100 \mathrm{~mL}$, com auxîlio da solução etanōlica de àcido acético a $50 \%$ (v/v), completan do-se o volume com o mesmo solvente. Desta solução foi trans ferida a aliqquota de $10 \mathrm{~mL}$ para balão volumētrico de $100 \mathrm{~mL}$ e o mesmo solvente foi empregado para completar volume.

A solução teste foi obtida mediante tomada de : ensaio de $5 \mathrm{~mL}$ da suspensão, empregando-se o mesmo solvente e igual esquema de diluição.

Entretanto, a solubilização inicial foi auxiliada com agitação magnētica, durante 10 minutos e esta amostra di lu $\overrightarrow{1} d a$ foi filtrada por papel de filtro Whatman no 1 .

A reação com solução de xantidrol seguiu o esquema seguinte:

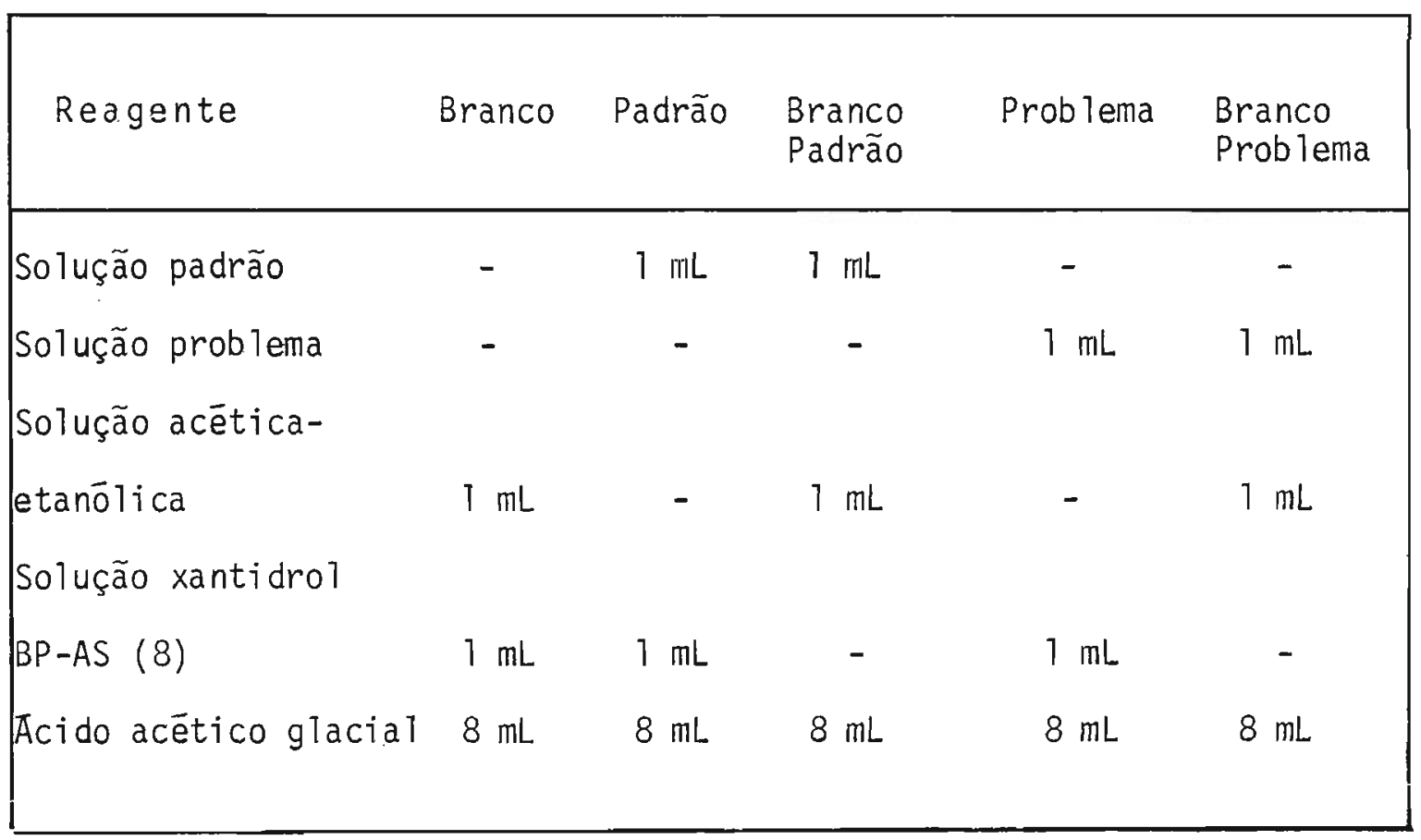


Após a mistura de cada um dos componentes de reação, em balão volumétrico de $10 \mathrm{~mL}$, estes foram aquecidos em banho de àgua fervente, durante 5 minutos. Após resfriamento dos ba 1ões em banho de gelo, completou-se o volume com ácido glacial, a fim de efetuar leitura fotométrica. Foi lido no espectrofotómetro, usando cubetas de $1 \mathrm{~cm}$ a $540 \mathrm{~nm}$.

o cálculo do teor de eritromicina foi segundo a fōr mula:
A $x C=K K \times D \times$ VM $=$ mg de estearato de eritro- P TE $\times 1000$ micina/dose terapéutica

tendo sido o resultado de cada amostra, média aritmética de determinações em duplicata.

Onde:

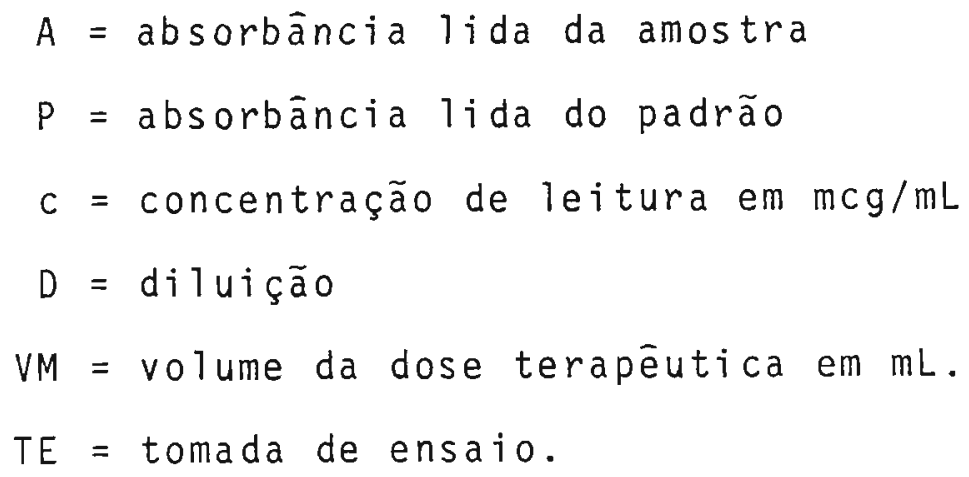


As Tabelas VI e VII apresentam o comportamento do estearato de eritromicina frente a diferentes EHL estudados das associaçōes de Polissorbato 60 - Span 60 e Polissorbato 80 - Span 80. Os valores de EHL estudados e suas respectivas proporções das associações acima citadas estão na Tabe1a I, (pāgina 31 ).

Os parāmetros analiticos ( $\mathrm{pH}$, densidade e viscosidade) das soluções de edulcorantes e das dispersões dos agen tes suspensores efetuados, estão presentes nas Tabelas IX e $X$ respectivamente (päginas 52 e 53 ). As figuras 7 a 12 re presentam graficamente o comportamento do estearato de eritromicina em relação a diferentes concentrações de glicerina, sorbitol a $70 \%$ e sacarose, assim como as Figuras 13 a 18 representam graficamente o comportamento deste fārmaco frente a diferentes concentrações de Boniasol ${ }^{R} 2600$, carboximetilcelulose sódica; Veegum ${ }^{R}$ HV, silicato de aluminio e magnésio; Viscosol ${ }^{R}$ RV, glicolato de amido sódico.

As fórmulas das suspensões de estearato de eritromicina do estudo prévio e definitivo estão discriminadas nas Tabelas II a V, päginas 39 a 42 .

Na Tabela XI (pāgina 54) constam valores de $\mathrm{pH}$, de $\underline{n}$ sidade e viscosidade das suspensões de 7 a 24 do estudo prévio. Estas amostras foram analisadas logo apōs a formulação e com repouso de 15 dias. As Figuras 1 a 6 representam 0 comportamento destas suspensões no decorrer deste período. 
25 a 48 do estudo definitivo estão nas Tabelas XII e XIII, päginas 55 e 56. Estas determinações foram efetuadas no início da observação, no caso, apōs 30 semanas. A representação grāfica da estabilidade das suspensões definitivas teatadas estão ilustradas nas Figuras 19 a 26.

Na Tabela VIII (pāgina 51) contēm valores de diāme tro médio, densidade aparente e teor de eritromicina, empregada como substāncia dispersa em todas as preparações. 
TABELA VI - COMPORTAMENTO DO ESTEARATO DE ERITROMICINA FRENTE A ASSOCIAÇAO DE POLISSORBATO 60 E SPAN 60 A $3,0 \%$.

\begin{tabular}{|c|c|c|c|c|}
\hline EHL & Molhabi & idade & Aspecto & Redispersibilidade \\
\hline & 1 hora & 3 horas & & 1 semana \\
\hline 6 & MP & MP & SC Tu & $D i$ \\
\hline 7 & MP & MP & SC Tu & $D i$ \\
\hline 8 & MP & MP & SC Tu & $D i$ \\
\hline 9 & MP & MP & SC Tu & $D i$ \\
\hline 10 & MT & MT & SS TU & $D i$ \\
\hline 11 & MT & MT & SS TU & $\operatorname{Re}$ \\
\hline 12 & MT & MT & SS Tu & $\operatorname{Re}$ \\
\hline 13 & MT & MT & SS Tu & $\mathrm{Fa}$ \\
\hline 14 & $M T$ & MT & SS Li & $\mathrm{Fa}$ \\
\hline
\end{tabular}

$$
\begin{aligned}
& M T=\text { Molhabilidade total } . \text { Tu }=\text { Turvo } \quad \text { Di }=\text { Dificil } \\
& M P=\text { Molhabilidade parcial Li = Lỉmpido } \quad \text { Re = Regular } \\
& F a=F \bar{c} c i l \\
& S C=\text { Sedimentação com compactação } \\
& S S=\text { Sedimentação sem compactação }
\end{aligned}
$$


TABELA VII - COMPORTAMENTO DO ESTEARATO DE ERITROMICINA FRENTE A ASSOCIAÇÃO DE POLISSORBATO 80 E SPAN 80 A $3,0 \%$.

EHL Molhabilidade

Aspecto

Redispers ib.i 1 idade

\begin{tabular}{llclll}
\hline & 1 hora & 3 horas & & 1 semana \\
10 & MP & MP & SC Tu & Di \\
11 & $M T$ & $M T$ & SC Tu & Di \\
12 & MT & $M T$ & SS Tu & Re \\
13 & MT & MT & SS Tu & Fa \\
14 & MT & MT & SS Li & Re \\
\hline \hline
\end{tabular}

$\begin{array}{lll}M T=\text { Molhabilidade total } & \text { Tu= Turvo } & \text { Di = Difícil } \\ M P=\text { Molhabilidade parcial } \quad \text { Li = Límpido } & \text { Re = Regular } \\ S C=\text { Sedimentação com compactação } & \text { Fa = Fãcil } \\ S S=\text { Sedimentação sem compactação } & \end{array}$

TABELA VIII - VALOR dO diÂMETRO MEdio, dENSidAde APARENTE E TEOR DE ERITROMICINA BASICA DO ESTEARATO DE ERITROMI CINA

diàmetro médio

densidade aparente

teor de eritromicina

( $\mu)$

$(\mathrm{g} / \mathrm{mL})$

$(\%)$

13.5

0,576

65,0 
TABELA IX - PARÃMETROS ANALITICOS DAS SOLUÇOES DE EDULCORANTES

Solução dos edulcorantes $\mathrm{pH}$ Densidade $(\mathrm{g} / \mathrm{mL})$ Viscosidade ( $\mathrm{cP}$ )

\begin{tabular}{|c|c|c|c|c|}
\hline Glicerina & a $10 \%$ & 5,10 & 1,030 & 12,5 \\
\hline Glicerina & $20 \%$ & 4,50 & 1,050 & 14,0 \\
\hline Glicerina & a $30 \%$ & 4,45 & 1,100 & 16,0 \\
\hline Glicerina & $40 \%$ & 4,30 & 1,120 & 20,0 \\
\hline Glicerina & $50 \%$ & 4,30 & 1,120 & 25,0 \\
\hline Sorbitol & $10 \%$ & 5,30 & 1,030 & 10,0 \\
\hline Sorbitol & $20 \%$ & 5,40 & 1,050 & 12,0 \\
\hline Sorbitol & $30 \%$ & 5,60 & 1,080 & 14,0 \\
\hline Sorbitol & $40 \%$ & 5,60 & 1,110 & 16,0 \\
\hline Sorbitol & $50 \%$ & 5,70 & 1,130 & 18,0 \\
\hline Sacarose & $10 \%$ & 6,30 & 1,050 & 11,0 \\
\hline Sacarose & $20 \%$ & 6,40 & 1,080 & 12,5 \\
\hline Sacarose & $30 \%$ & 6,45 & 1,125 & 18,0 \\
\hline Sacarose & $40 \%$ & 6,50 & 1,760 & 19,0 \\
\hline Sacarose & $50 \%$ & 6,50 & 1,200 & 35,5 \\
\hline
\end{tabular}


TABELA X - PARÂMETROS ANALITICOS DAS DISPERSÖES DOS AGENTES SUSPENSORES

$\mathrm{pH} \quad$ Densidade $(\mathrm{g} / \mathrm{mL})$ Viscosidade $(\mathrm{cP})$

\begin{tabular}{|c|c|c|c|c|c|}
\hline Boniasol ${ }^{R}$ & 2.600 & $0,3 \%$ & 6,10 & 1,001 & 29,0 \\
\hline Boniaso ${ }^{R}$ & 2.600 & $0,6 \%$ & 6,30 & 1,005 & 51,0 \\
\hline Boniaso ${ }^{R}$ & 2.600 & $0,9 \%$ & 6,35 & 1,006 & 80,0 \\
\hline Boniaso ${ }^{R}$ & 2.600 & $1,2 \%$ & 6,39 & 1,008 & 124,0 \\
\hline Boniasol ${ }^{R}$ & 2.600 & $1,5 \%$ & 6,40 & 1,009 & 211.0 \\
\hline Veegum $^{R} H V$ & & $0,3 \%$ & 8,5 & 1,001 & 9,0 \\
\hline Veegum $^{\mathrm{R}} \mathrm{HV}$ & & $0,6 \%$ & 8,8 & 1,005 & 12,0 \\
\hline Veegum $^{R} \mathrm{HV}$ & & $0,9 \%$ & 9,00 & 1,009 & 15,0 \\
\hline Veegum $^{R} \mathrm{HV}$ & & $1,2 \%$ & 9,10 & 1,010 & 16,0 \\
\hline Veegum $^{R}$ HV & & $1,5 \%$ & 9,10 & 1,011 & 19,0 \\
\hline$V$ iscoso $1^{R}$ & RV & $0,3 \%$ & 6,40 & 1,001 & 15,0 \\
\hline Viscoso $1^{R}$ & RV & $0,6 \%$ & 6,45 & 1,002 & 20,0 \\
\hline$V$ iscosol ${ }^{R}$ & RV & $0,9 \%$ & 6.39 & 1,005 & 36,0 \\
\hline Viscosol ${ }^{R}$ & $\mathrm{R} !$ & $1,2 \%$ & 6,49 & 1,008 & 46,0 \\
\hline$V$ iscosol ${ }^{R}$ & RV & $1,5 \%$ & 6,40 & 1,011 & 86,5 \\
\hline
\end{tabular}


TABELA XI - PARĀMETROS ANALITICOS DAS SUSPENSÕES DE ESTEARATO DE ERITROMICINA DO ESTUDO PREVIO.

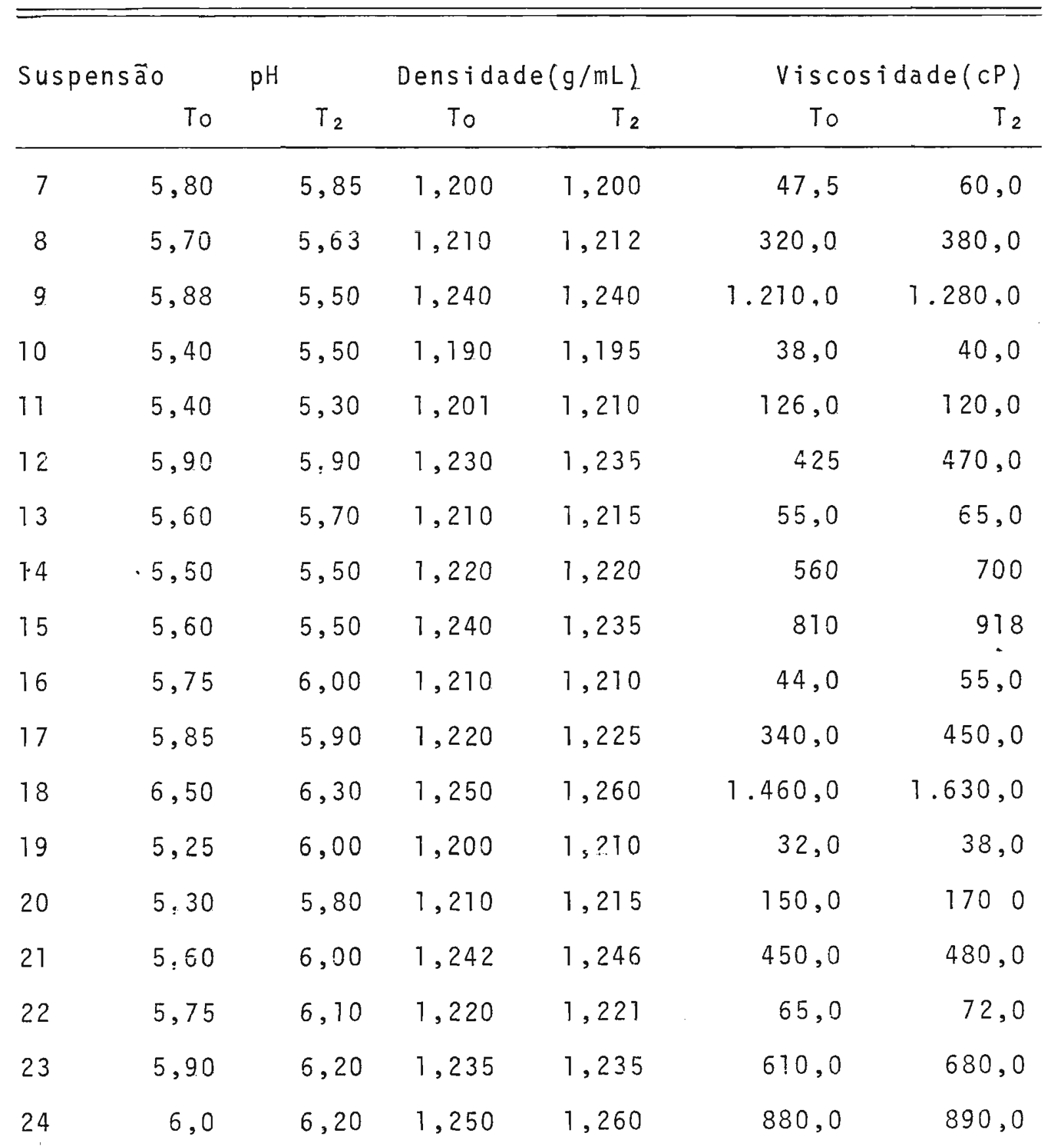

$T_{0}=\operatorname{apōs}$ a formulação

$T_{2}=$ após duas semanas 


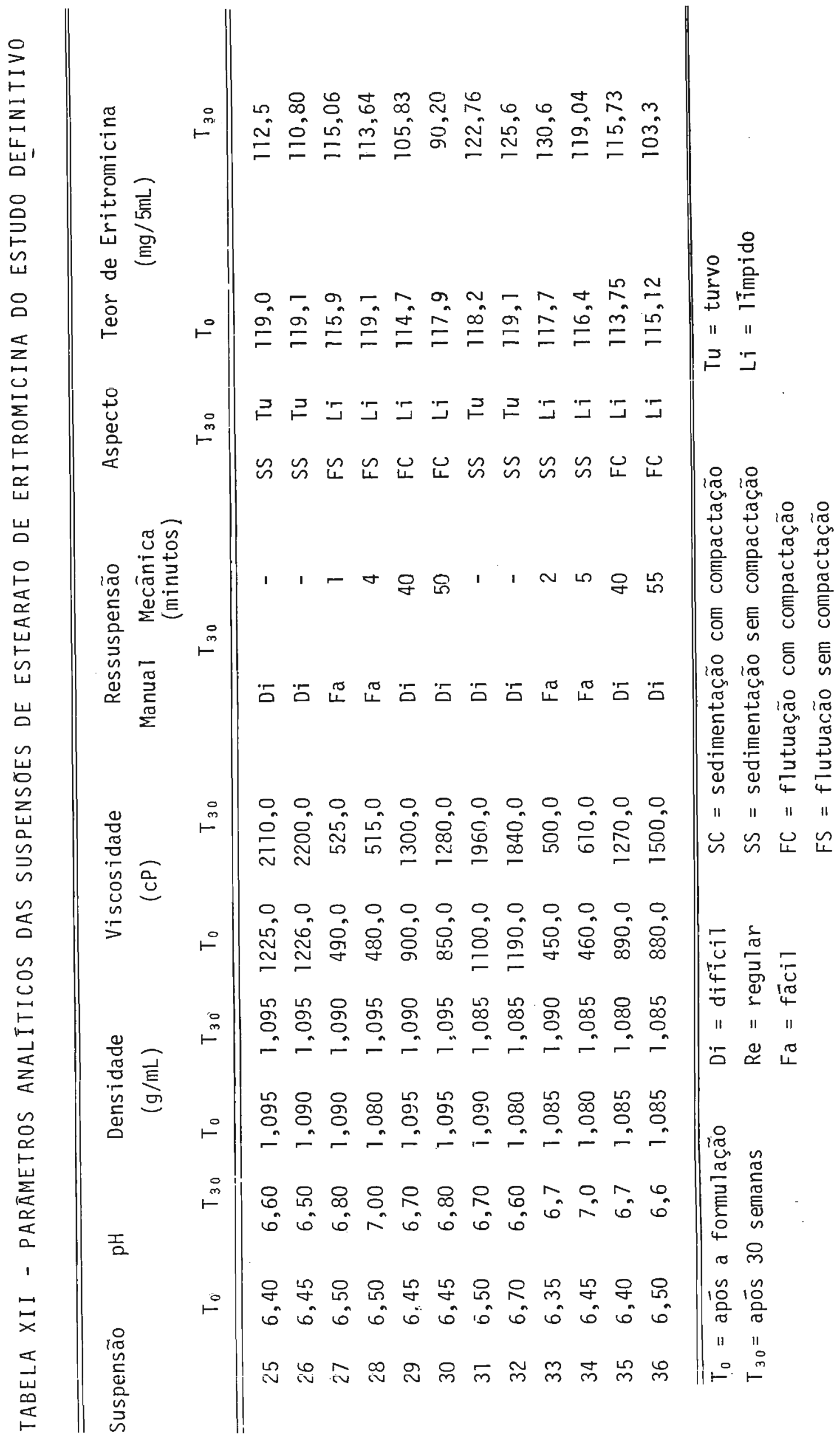




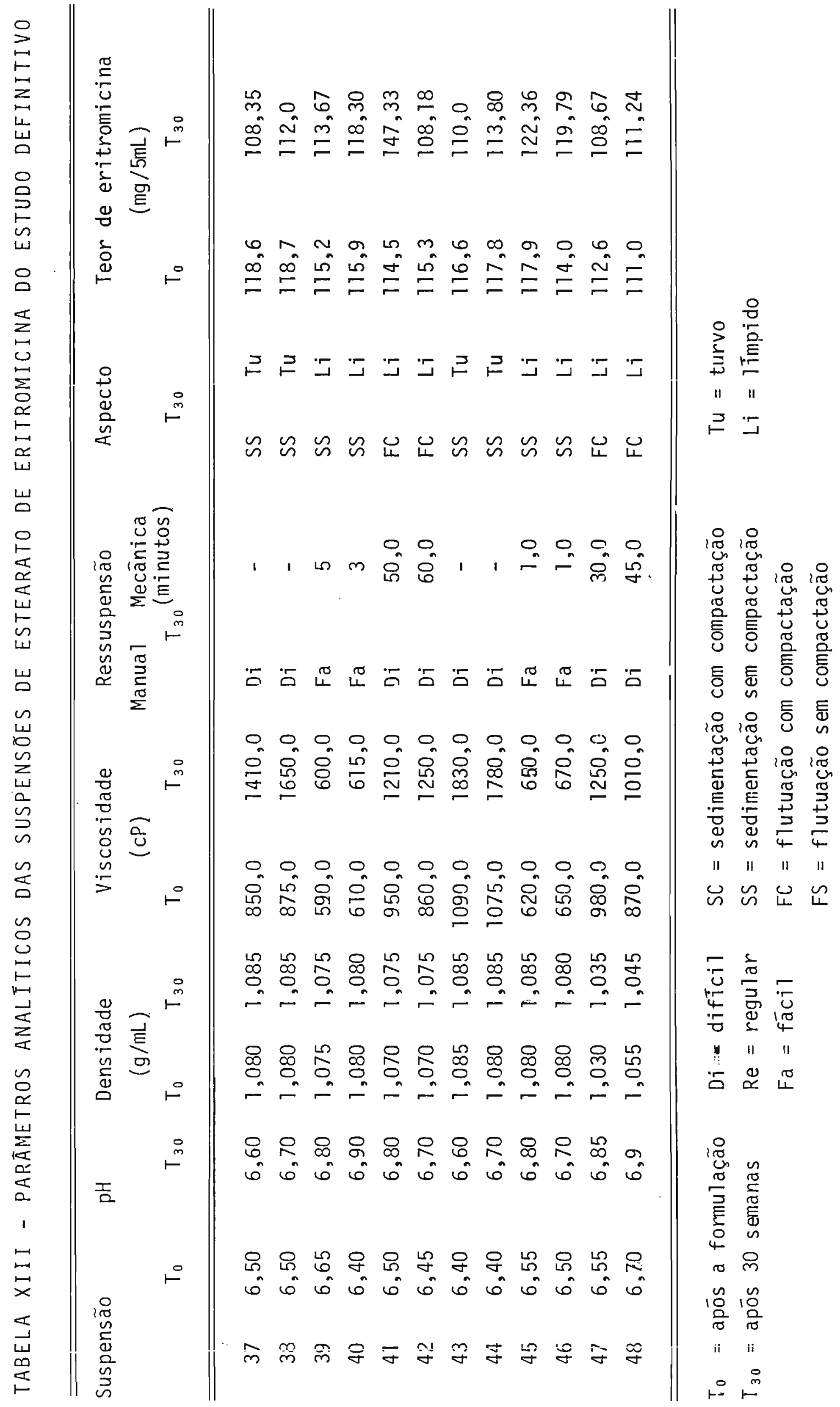



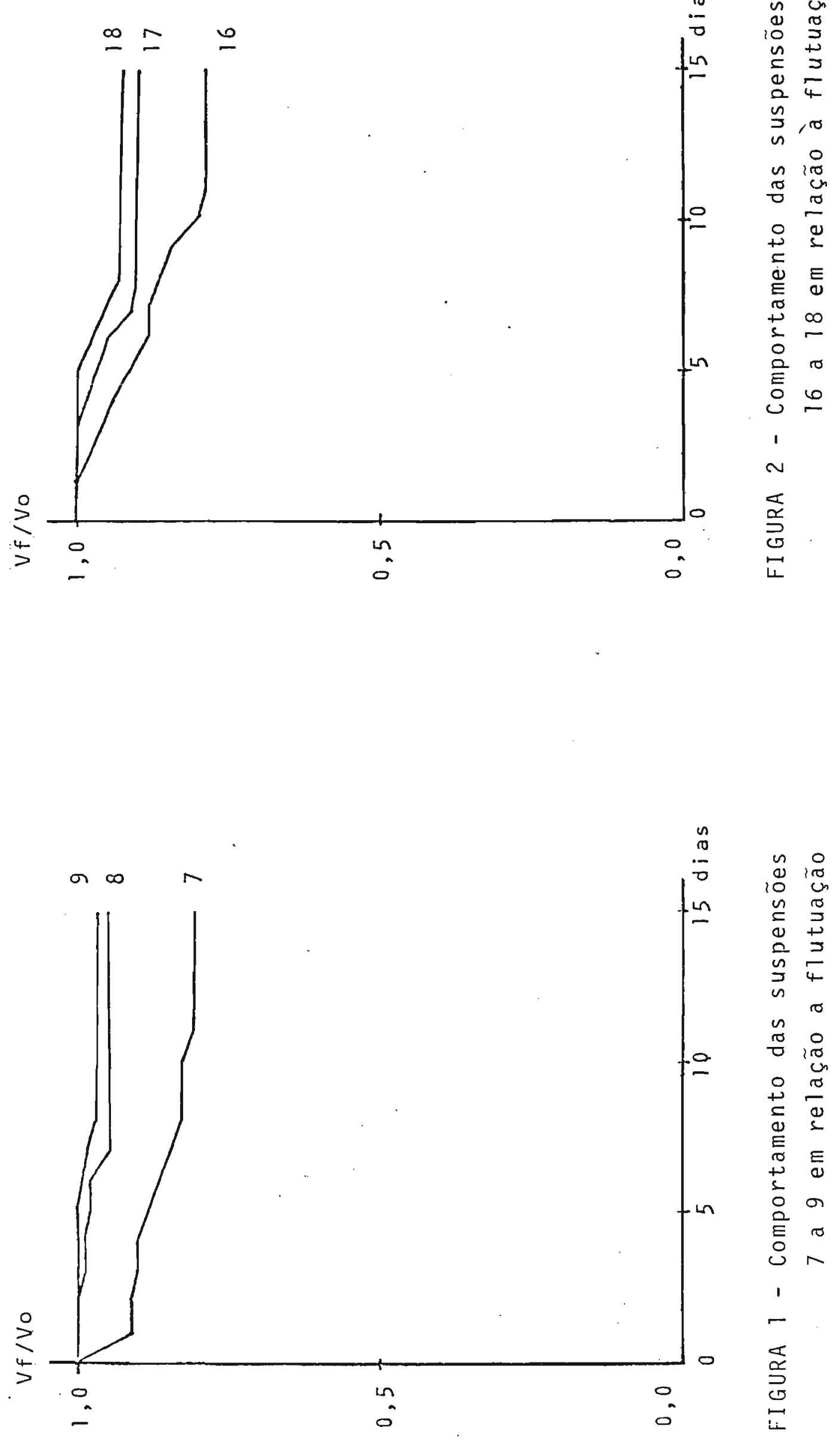

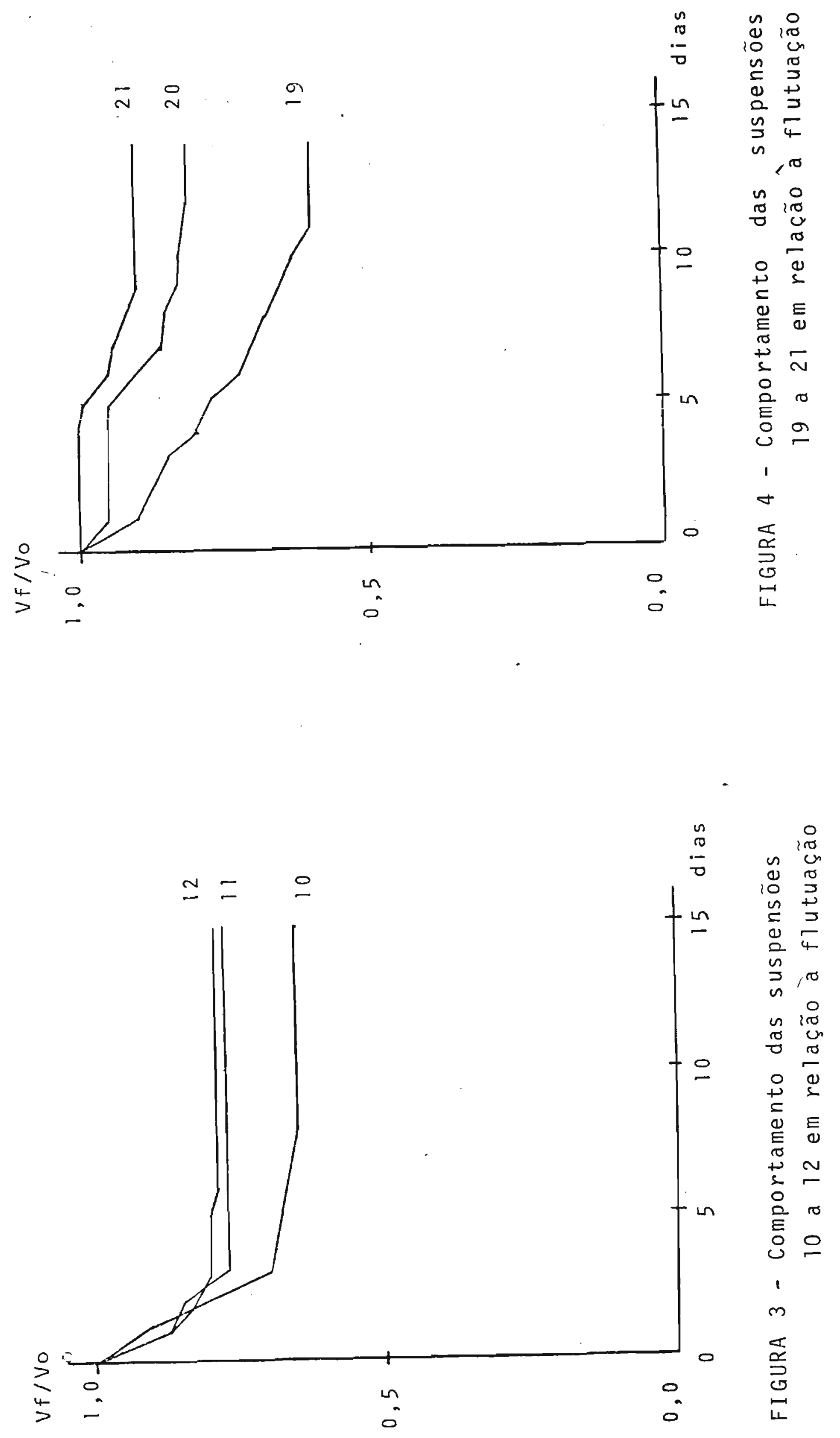

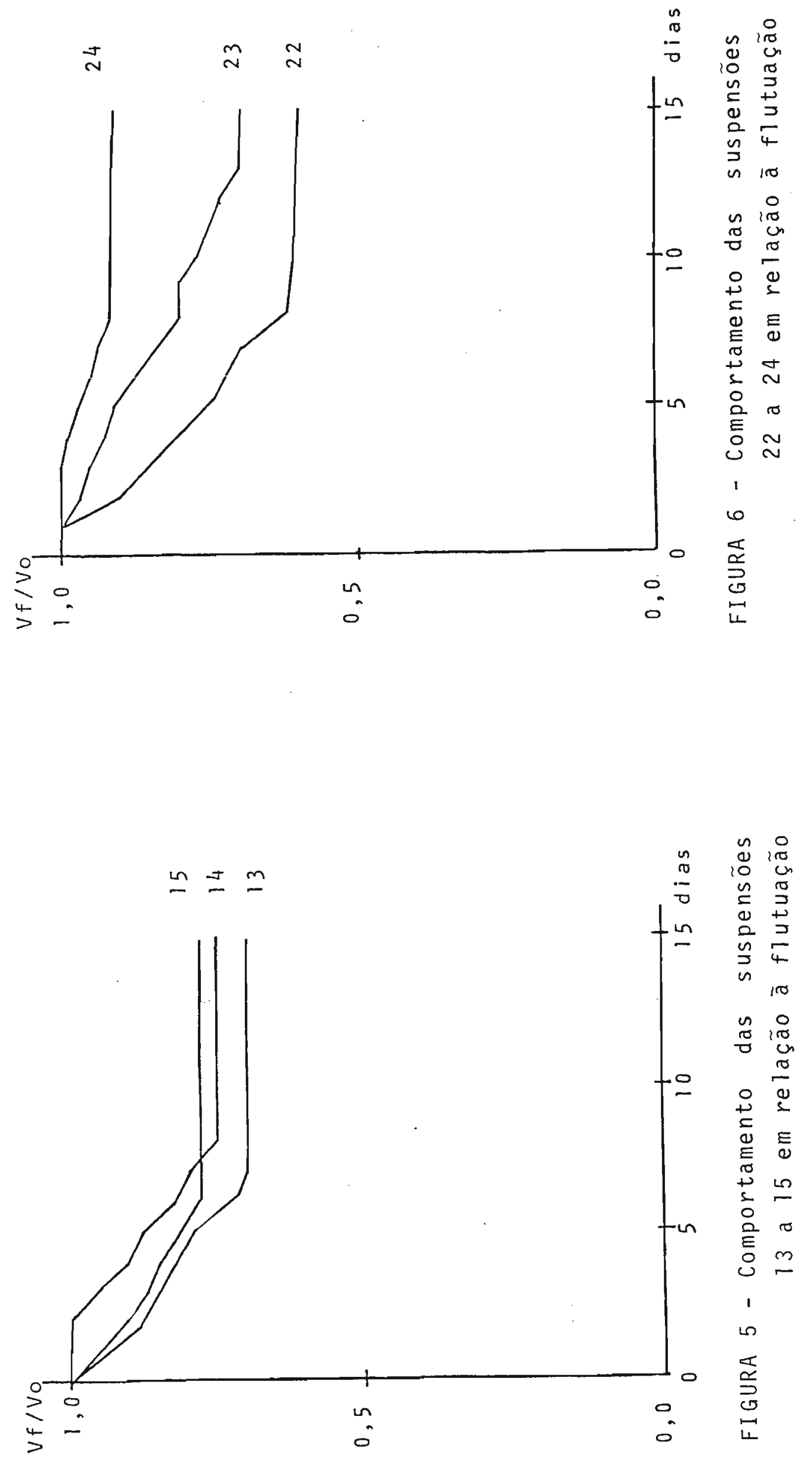


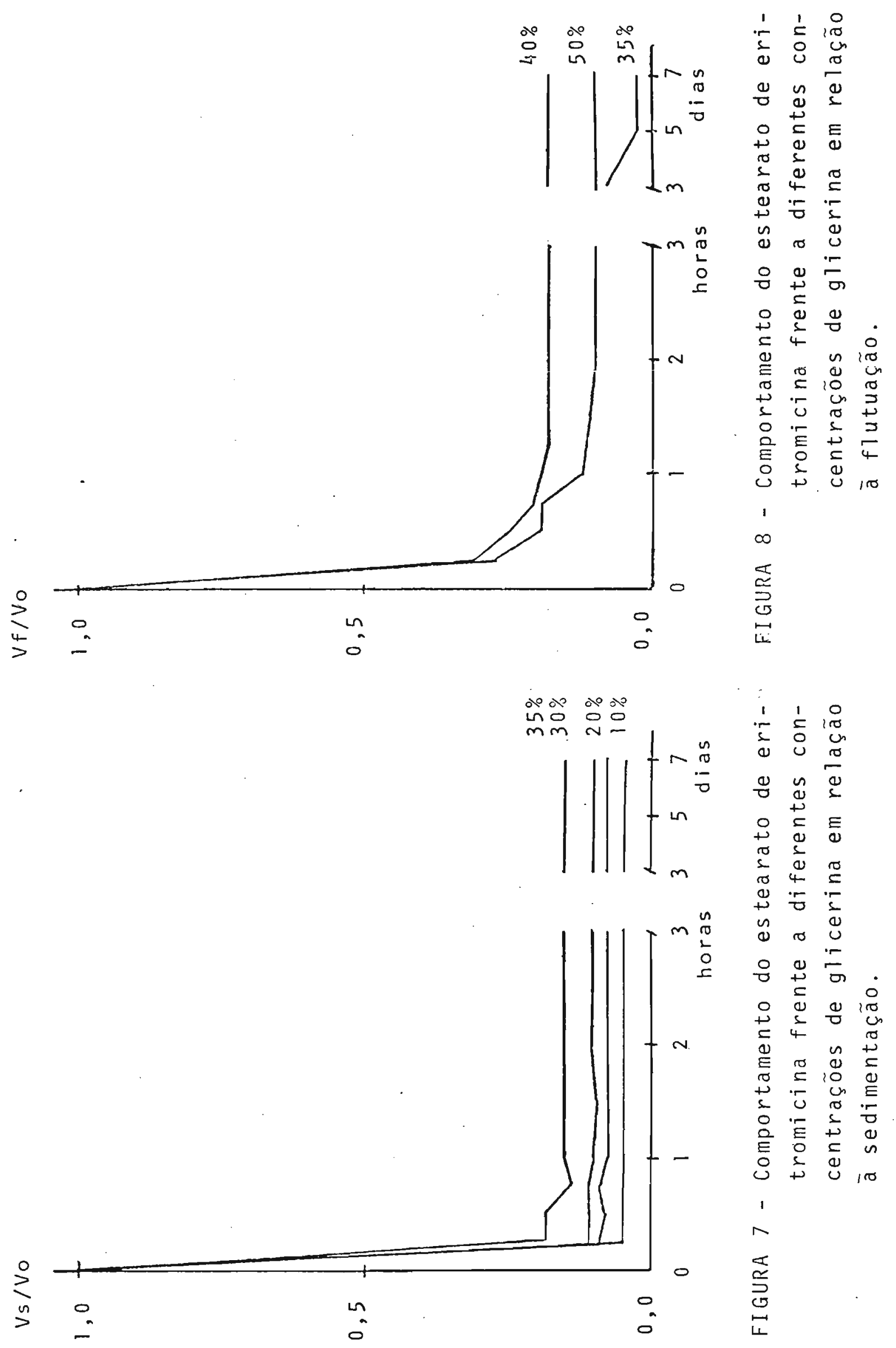



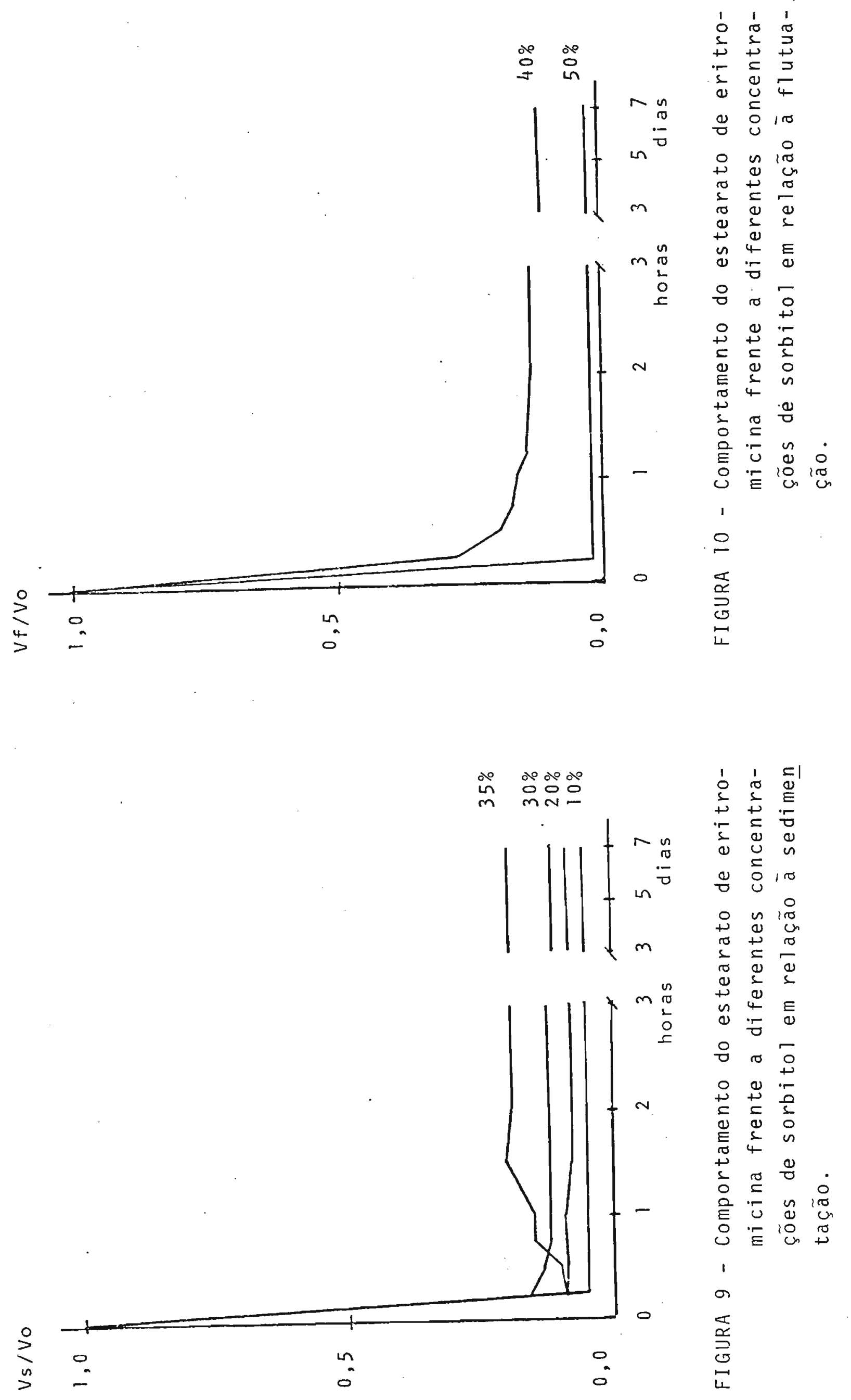

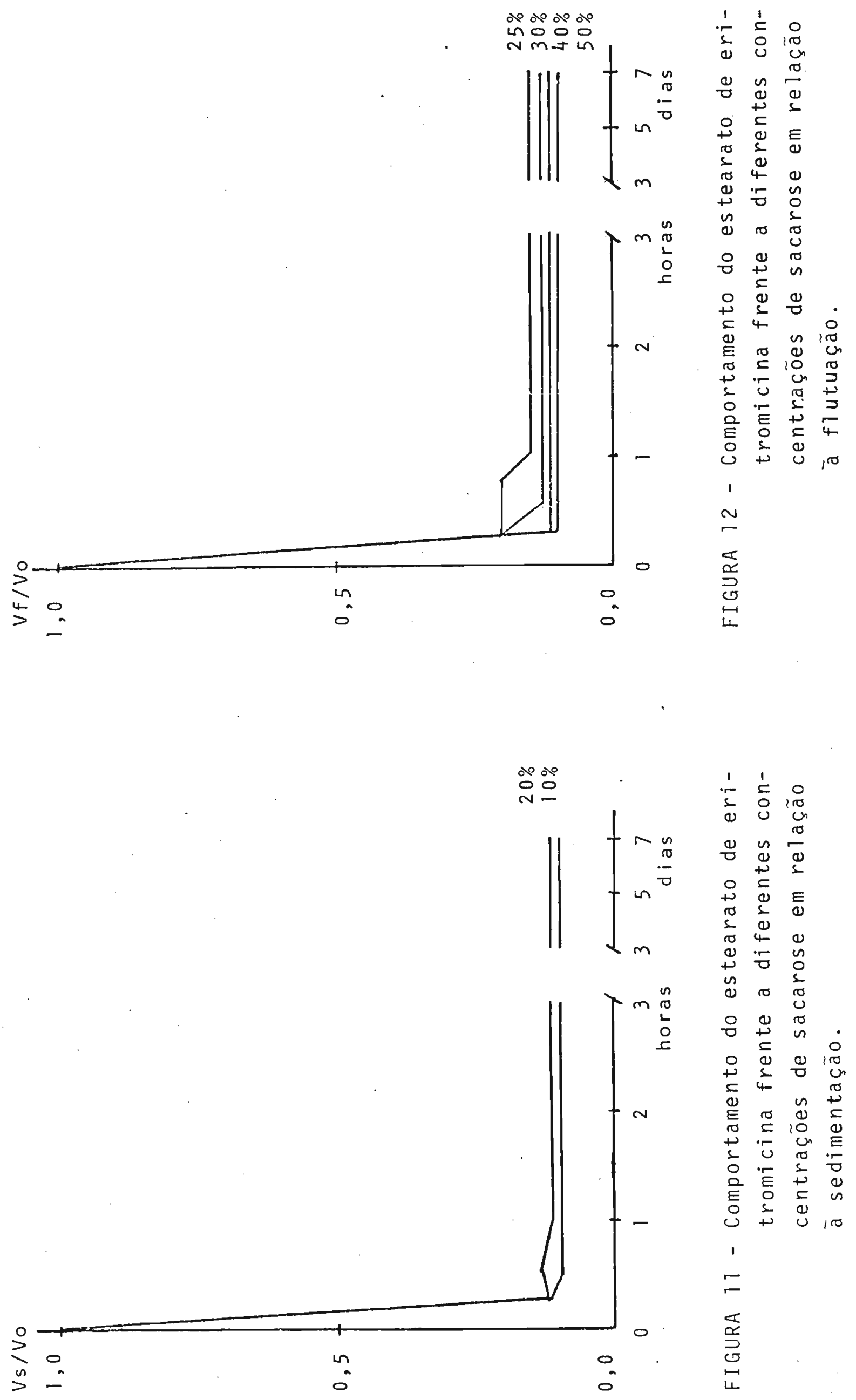

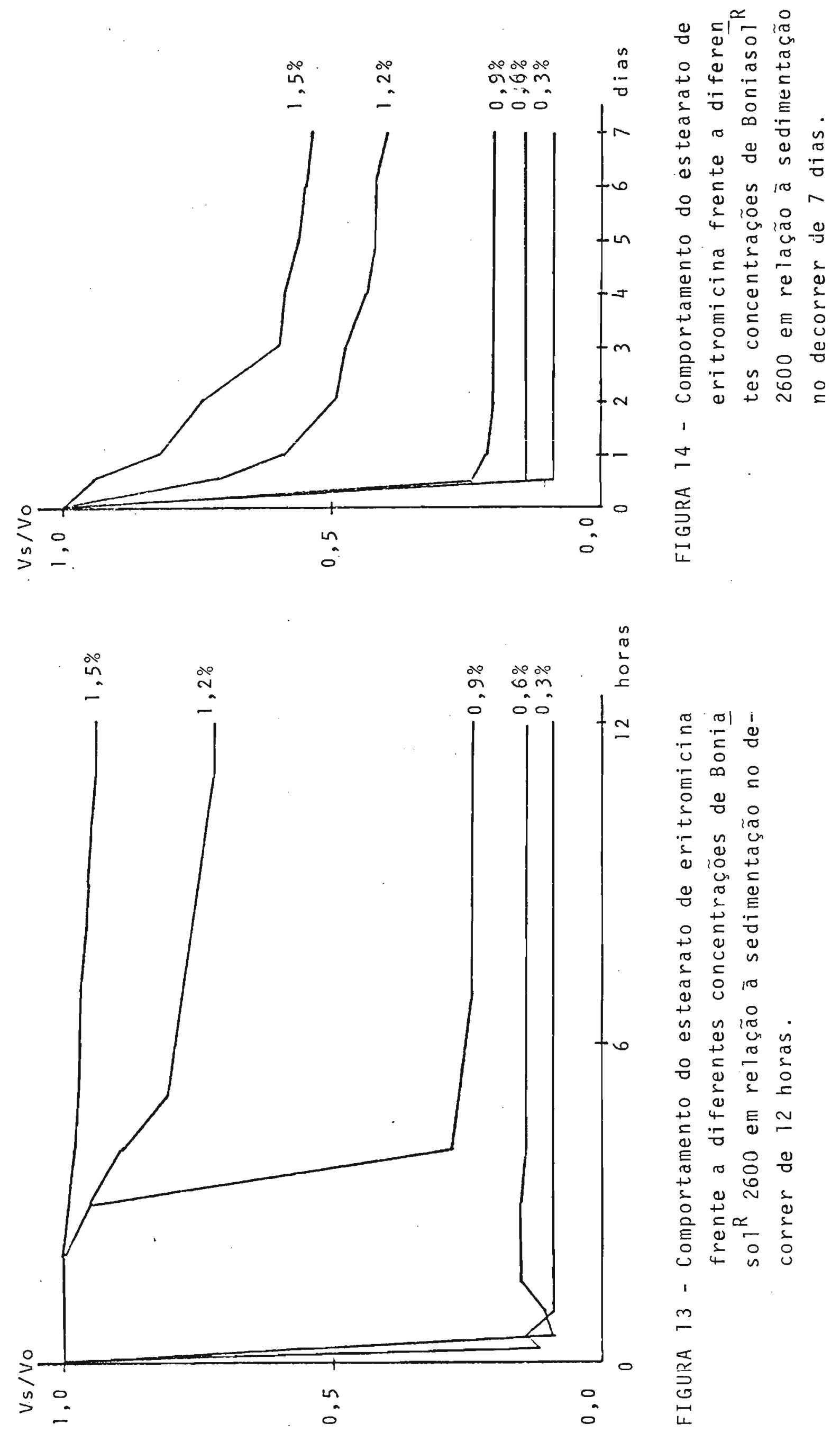

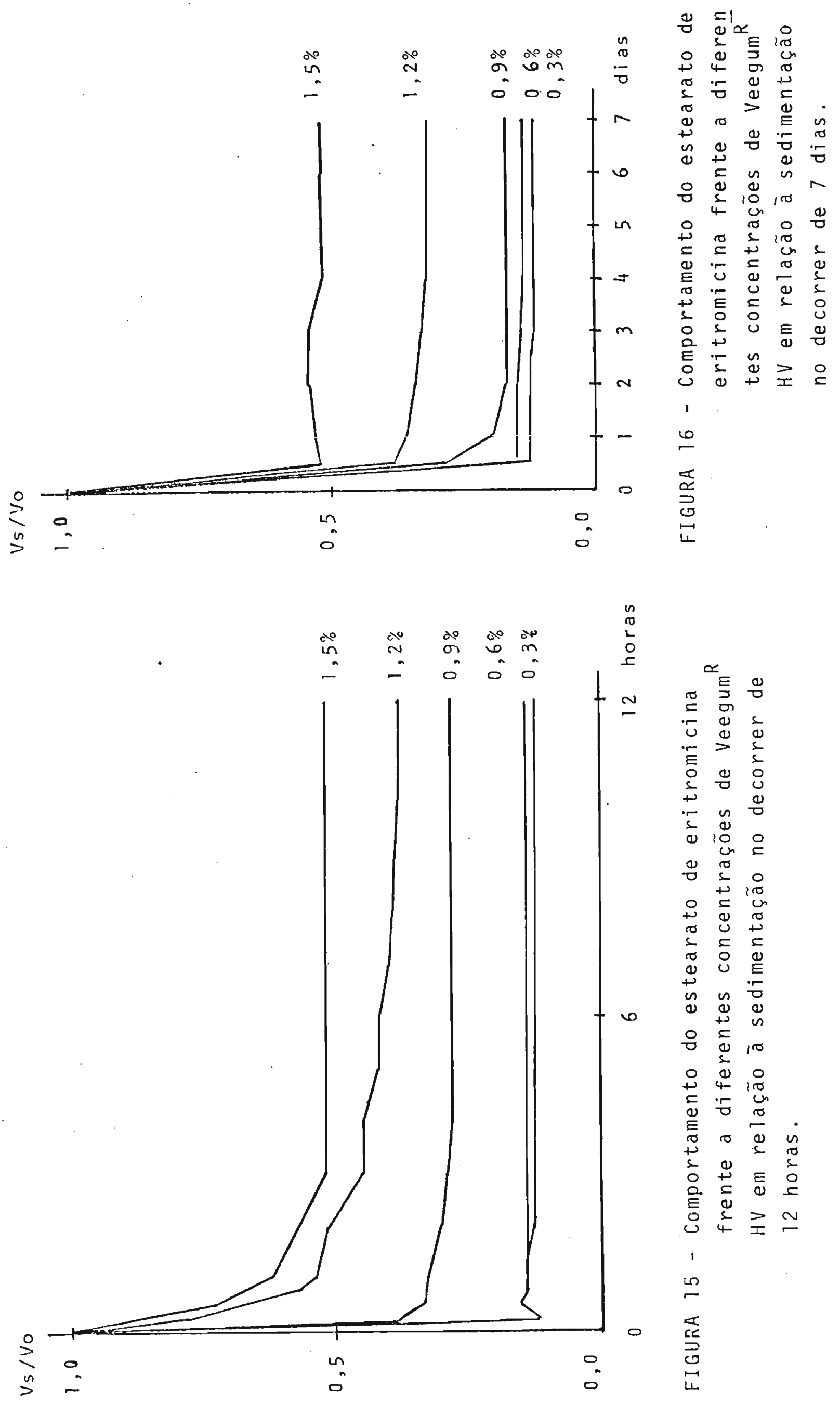


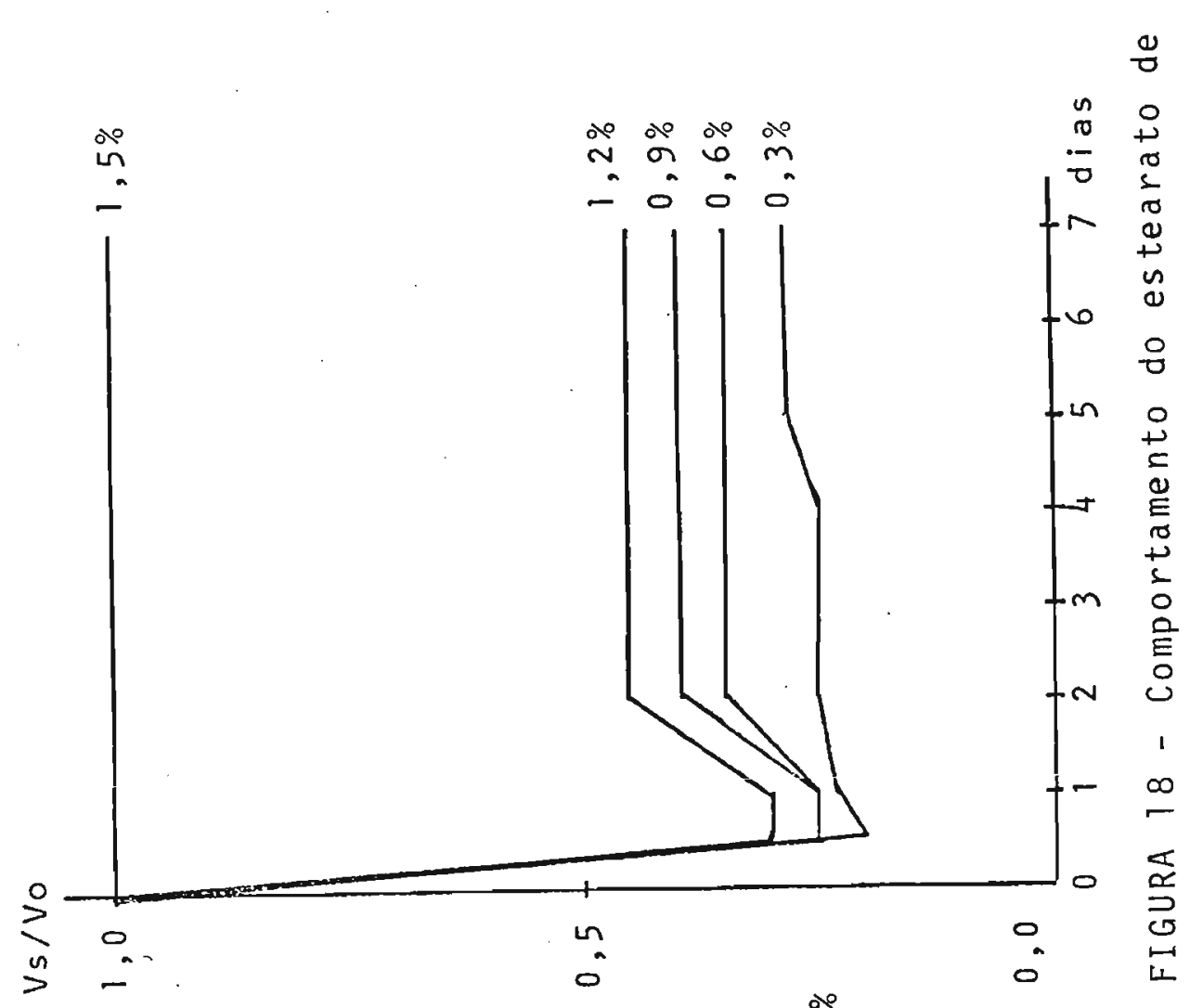

당

10

4000

T

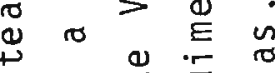

\&

○

- 4 un 0 告

$=\stackrel{5}{=}$ 范s

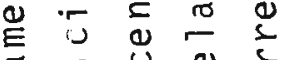

苧

잉 E

立

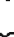

-

垔

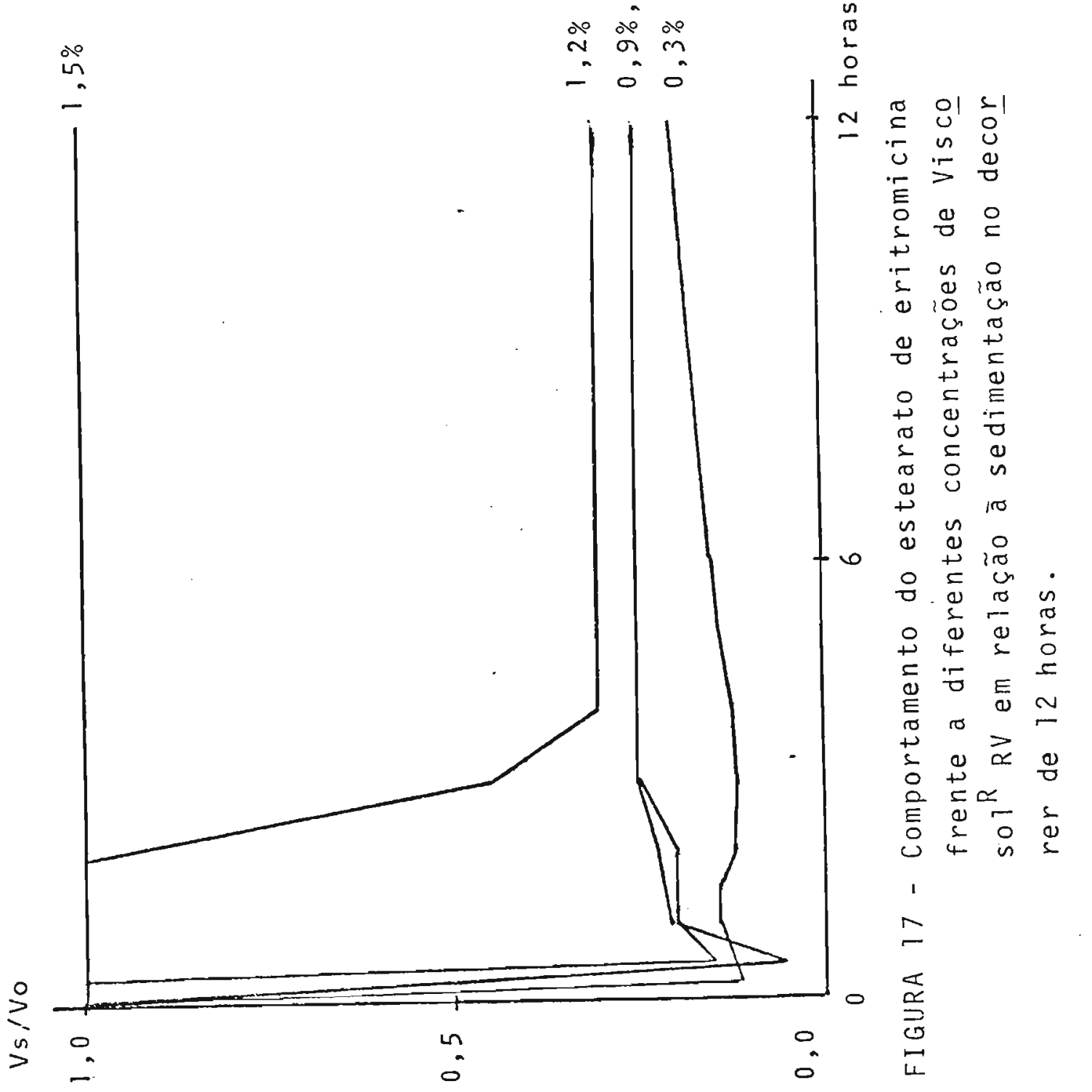




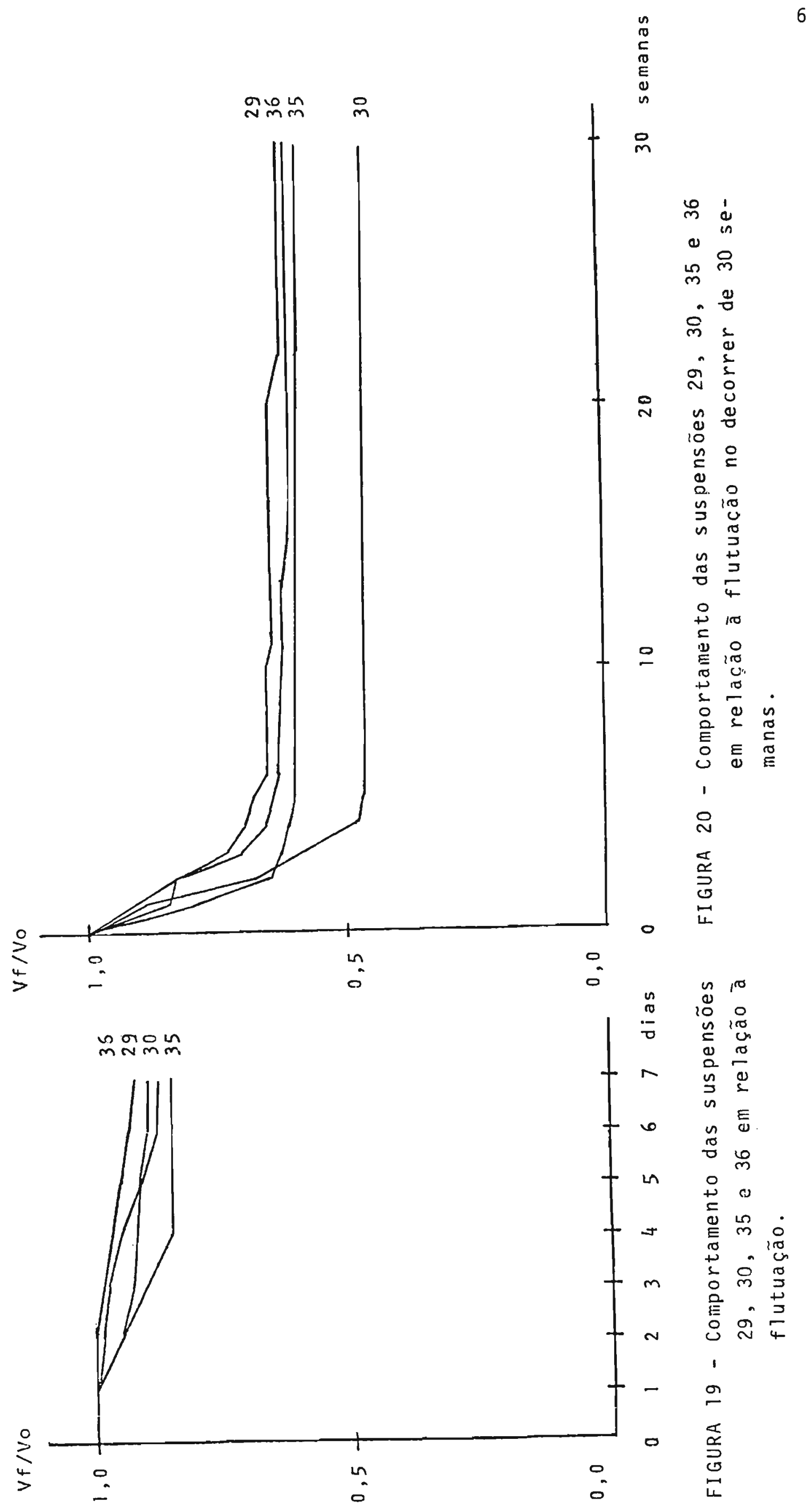




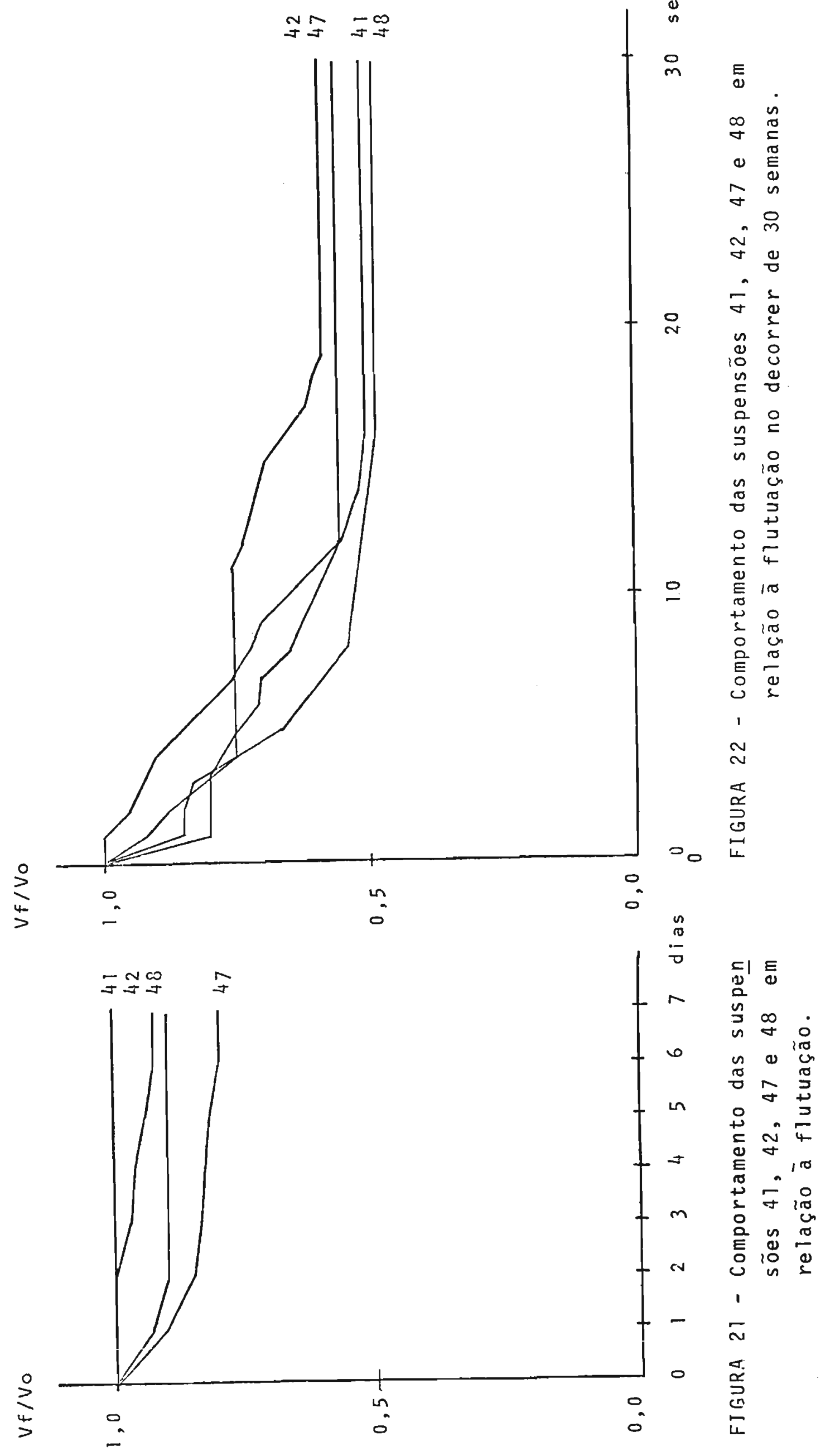




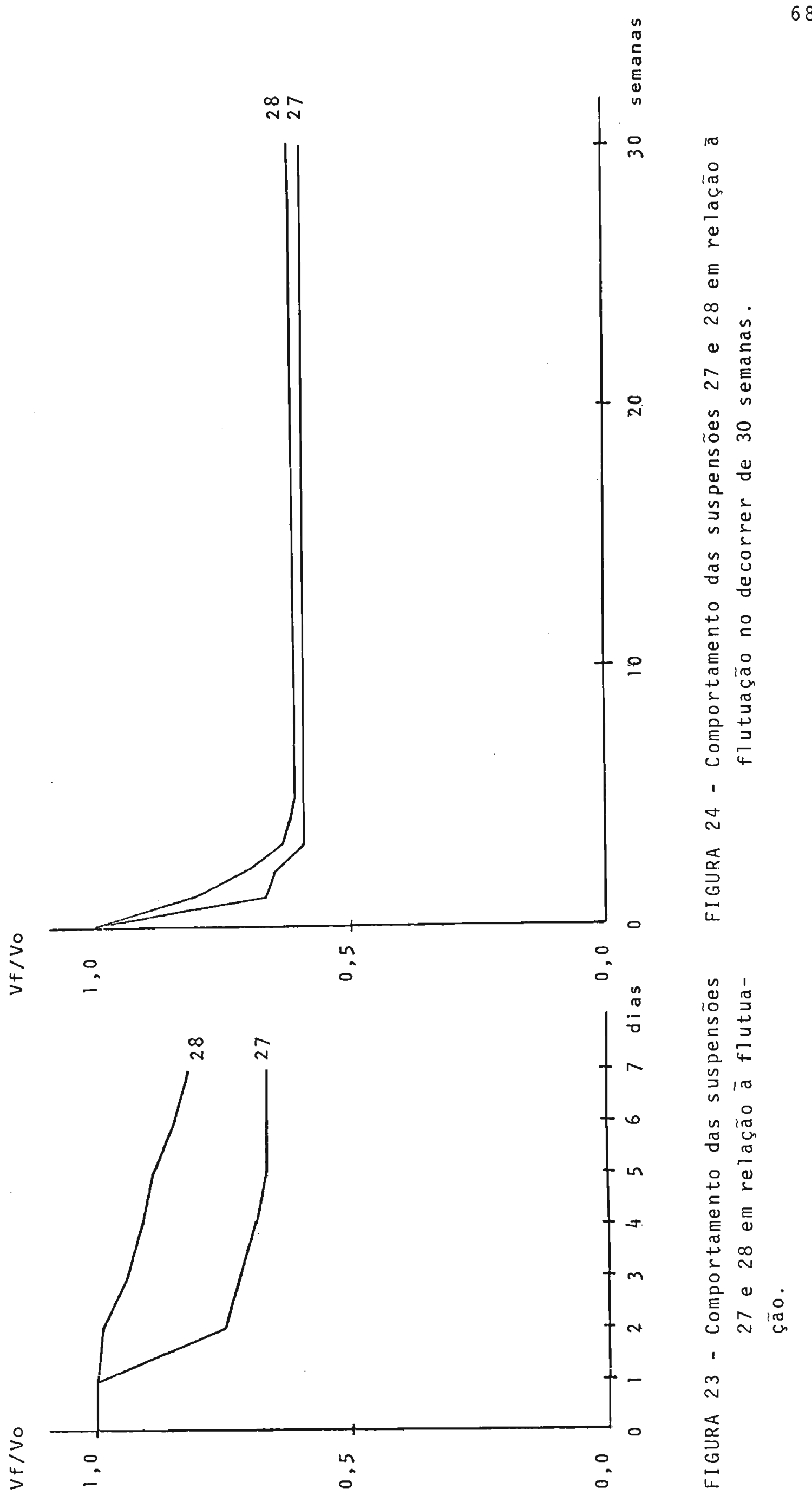




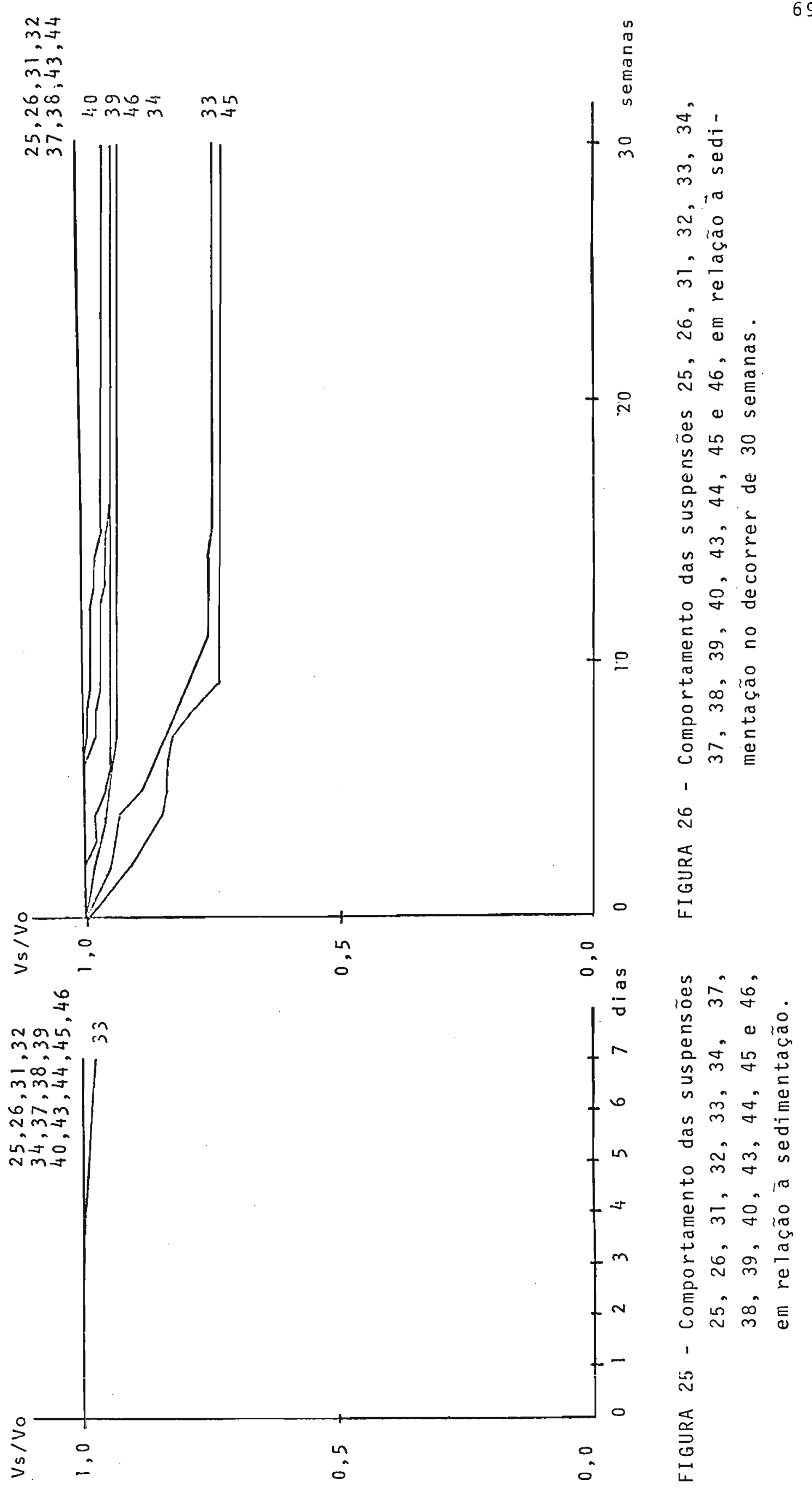


Como as suspensões constituem um sistema complexo e termodinamicamente instāvel, cuja instabilidade è influencia da por vários fatores físico-quỉmicos, a formulação das mesmas requer estudos criteriosos. Portanto, não se trata apenas de simples incorporação do fārmaco no veículo, sob agita ção. O que se espera deste tipo de forma farmacéutica é que haja homogeneidade de dispersão das partículas até o momento de sua utilização pelo paciente.

Com vistas ao estudo farmacotécnico de suspensões, SAMYN (96) apresenta proposta metodolögica subdividida em três etapas, a saber: conhecimento sobre as caracteristicas da partícula a ser suspensa, formulação para obtenção de resultados prévios e, finalmente, o estudo das fōrmulas defini tivas, com acompanhamento da estabilidade ao longo do tempo.

Sabe-se que variações do tamanho, forma e densidade das particulas modificam a estabilidade das suspensões, devendo, para cada caso, efetuar adequação dos coadjuvantes far macotécnicos. Neste trabalho, considerou-se como caracterīs tica fisica do estearato de eritromicina aquela encontrada no mercado nacional, com variações no tamanho e forma de partīculas, não tendo sido o mesmo submetido ao processo de moagem.

As preparações do estudo prēvio continham alguns com ponentes básicos, mantidos constantes, variando-se apenas os agentes suspensores quanto à natureza e concentração.

Considerou-se o período de duas semanas como o tempo necessārio para avaliar o comportamento destas dispersões, 
apesar de haver opiniões controvertidas a respeito. Segundo SCHUMACHER (99), uma semana é suficiente para conhecer o com portamento do sistema suspensor.

Ao lado do tempo de manutenção estática das prepara ções em estudo, outro aspecto a ser considerado reside no controle analitico dos parāmetros indicativos da estabilidade destas formulações. Segundo diversos autores $(1,56,79$, $81,82,86,91,92,93,97,104)$, säo considerados aspectós importantes a determinação do tamanho das partículas, anāiises do aspecto e volume do färmaco disperso, medida eletroci nética ou potencial zeta, além das características reológicas.

Conforme os dados da Tabela XI e Figuras 1,3 e :5, os valores de densidade, viscosidade e pH das suspensões 7 a 15 não se alteraram, ou as alterações foram diminutas neste espaço de 2 semanas. Entretanto, a homogeneidade da dispersão foi sendo alterada, com a tendēncia de flutuação das par tỉculas a partir de 24 horas após a manipulação. 0 volume do material flutuado estabilizou-se a partir do terceiro dia pa ra a suspensão nọ 11 e a partir do décimo dia para o de nọ 7. Por outro lado, quando se considera a relaçäo Vf/Vo no final de duas semanas, pode-se afirmar que as trēs preparações (nọs 7 a 9) contendo Boniasol ${ }^{R}$ 2600 e carboximetilcelulose sódica foram mais estāveis. Além disto, as concentrações de 0,6 e $1,2 \%(p / v)$ proporcionaram melhor estabilidade do que a de $0,3 \%$. os outros agentes suspensores acusaram semelhança no volume do material flutuado e, dentro de cada grupo, houve relação direta entre a concentração e o volume flutuado.

A resolução de problemas decorrentes da flutuação de particulas no meio 1 íquido estā intimamente relacionada :com 
a adição de tensoativos. Estas, ao diminuirem a tensão super ficial do liqquido em questão, favorecem a molhabilidade do fārmaco disperso $(1,86,87)$, alēm de diminuir a energia 1ivre das particulas (91) e evitando o crescimento ou aglomeração de cristais (48).

Diversos autores estudaram a influência de tensoativos na estabilidade de suspensões $(5,11,28,76,77)$. Trata-se de estudo complexo que requer tempo longo de acompanhamento. Entretanto, mētodos mais rāpidos são aqueles desenvol vidos por DRAVES ( 1,87$)$, ZACEK (112) e RIGAMONTI e RUGGINENTI (91), os quais foram ligeiramente modificados e empregados no presente trabalho.

A escolha de tensoativos do tipo não iōnico residiu no fato de estes serem mais compativeis com muitos fármacos. Alēm disto, segundo BERTUZZI (5), a associação PolissorbatoSpan, por ser mistura de componentes com caracteristicas lipófila e hidrōfila, favorece sobremaneira a formação de sistema floculado.

Apesar de Span 60 e Polissorbato 60 apresentarem ra dical estearato, que $\bar{e}$ o mesmo que se encontra na eritromici na empregada, os valores de EHL 6 a 9 , resultantes desta associação, a 3\%, não permitiram perfeita molhabilidade do pó. Conforme a Tabela VI (página 50), a molhabilidade foi total a partir do valor 10 , mas a redispersibilidade das suspensões após uma semana de repouso, foi de regular a fācil naquelas de 11 a 14 . Além disto, estas 4 preparaçoes apresentavam van tagem de não terem o sedimento compactado, característica in desejāvel para as suspensões. 0 aspecto do líquido sobrenadante, se turvo ou límpido, pouca relação apresenta no tocan 
te à facilidade de redispersão, propriedade esta importante na homogeneização do fármaco pelo paciente, no momento da subdivisão de dose posológica.

Com relação aos valores de EHL obtidos pela associ ação do par 60, diversos autores indicam a faixa de 6 a 9 $(26,41,87)$. Entretanto, analisando os resultados do presente trabalho, a preparação com EHL de valor 13 pode ser considerada a melhor. Apesar desta conclusão, a transposição deste resultado para a formulação de suspensões foi modificada, pois, no lugar de $3 \%(p / v)$ adotou-se $1 \%(p / v)$ des te par de tensoativos. Isto foi decorrēncia da preparação e anāilise das caracteristicas reológicas das suspensões 1 a 3, da Tabela II (pägina 39). Estas, por serem altamente vis cosas, não apresentaram fluidez suficiente para serem verti das do frasco.

Com relação ao par 80 , apesar da molhabilidade ter sido perfeita com valores de EHL de 11 a 14, devido ao tipo de sedimento formado e a dificuldade na redispersão do sistema, foram escolhidos aqueles de 12 e 13 como sendo de características desejāveis, sendo ideal o de EHL 13.

Baseado nesta conclusão e transpondo o uso de $3 \%$ (p/v) deste par, foram preparadas as suspensões de nos 16 a 24, conforme as fórmulas da Tabeìa III (pāgina 40). Analisando os dados inerentes a estas preparações, nas figuras 2 , 4 e 6 e Tabela XI (página 54), apesar da incorporação de ten soativos, havia flutuação do estearato de eritromicina no vei culo em questão. Pelo estudo comparativo das figuras 1 e 2 , em que as suspensões 7 a 9 e 16 a 18 diferem quali- e quanti tativamente quanto ao par de tensoativos, pode-se afirmar que 
não existe diferença no comportamento físico da dispersão. Entretanto, quando o agente suspensor foi constituído de vee gum HV (Figuras 3 e 4), as preparações contendo $3 \%$ do par 80 demoraram mais para atingir o ponto de estabilidade, alēm de terem acusado valores de Vf/vo menores que com o par 60, a $1 \%(p / v)$. Quando se efetua confronto semelhante entre as pre parações contendo Viscosol ${ }^{R} \mathrm{RV}$, houve, no caso do par 80 , acen tuada diferença nos valores de Vf/Vo (Figuras 5 e 6), manten do a relação direta entre a concentração do agente suspensor e maior volume do material flutuado. Portanto, estes dados comparativos não permitem afirmar qual förmula seja melhor, tendo em vista a persistēncia da caracterīstica de flutuação das particulas de estearato de eritrominica, devendo modificar outros parâmetros físicos.

Pode-se recorrer às modificações de outros constitu intes da fórmula, como os edulcorantes. Neste sentido, ZATZ e LUE (113) estudaram a influéncia de propilenoglicol e sorbitol na estabilidade física de suspensões contendo sulfamerazina e salicilamida; JONES e colaboradores (52), glicerina em relação a sulfaguanidina e ROHDWALD (92), glicerina e sor bitol frente ao óxido de zinco e talco.

No presente trabalho, os edulcorantes adicionados às suspensões foram glicerina, sorbitol a $70 \%$ e sacarose. A in trodução destes componentes, sempre isoladamente, visou alte rar as caracteristicas de viscosidade e densidade das preparações. No caso da glicerina, conforme as Figuras 7 e 8 , a caracterỉstica de flutuação passava a inverter, com sedimentação rāpida em tempo de 24 horas, quando a concentração des ta era abaixo de $35 \%(p / v)$. A flutuação estabilizava, tambēm, 
no mesmo intervalo de tempo apōs a manipulação, acusava valo res de Vf/Vo muito inferiores aos já encontrados em preparações anteriores, de nọ 7 a 24.

Em relação ao sorbitol $70 \%$, houve comportamento semelhante, com aparecimento de flutuação das particulas de es tearato de eritromicina a partir de $40 \%$ (p/v). Fato análogo foi constatado com sacarose, a partir de $30 \%$ ( $p / v)$.

Observando os dados analíticos da Tabela IX (pāgina 52), referentes às soluções de edulcorantes, quando a densidade é maior que $1,110 \mathrm{~g} / \mathrm{mL}$ ocorre o fenômeno da flutuação. Este fato é confirmado, também pelos valores de densidade ve rificados nas suspensões de 7 a 24 , da Tabela XI. Logo, hä necessidade em compatibilizar a densidade aparente das partí culas com a da fase dispersante. Segundo a equação de STOKES (87) e de HIGUCHI-KOSENY (48), a estabilidade será tanto maior, quanto menor a diferença entre os valores de densidade. Ape sar disto, NASH (80) e SCHUMACHER (100) comentam sobre a dificuldade técnica na introdução de modificações na densidade da fase dispersante com a finalidade de igualar com a do fár maco. Assim, o sorbitol $70 \%$ pode aumentar a densidade até l,3 $\mathrm{g} / \mathrm{mL}$, mas eleva demasiadamente a viscosidade do sistema (87). Para o caso especîfico de estearato de eritromicina, a solução seria a diminuição da densidade da fase continua, para evitar o fenōmeno da flutuação.

Segundo PRISTA e ALVES (87), a densidade dos färmacos é, em geral, mais elevada que a fase dispersante, varian do de 1,2 a $1,3 \mathrm{~g} / \mathrm{mL}$. Entretanto, BERTUZZI (15), empregou no seu estudo caulinin comin $0,50 \mathrm{~g} / \mathrm{mL}$; e o vaior de densidade de es tearato de eritromicina è de $0,576 \mathrm{~g} / \mathrm{mL}$. 
Associado a este parāmetro, existe o problema da viscosidade. Com vistas à obtenção de dados experimentais relacionados com os 3 agentes suspensores, diferentes concentrações dos mesmos foram preparadas em ägua destiliada. Conforme os resultados da Tabela X (pāgina 53), a densidade de todos os casos foi bem inferior a $1,110 \mathrm{~g} / \mathrm{mL}$, em igera 1 , com pouca variação entre as mesmas, embora haja diferença nos valores de viscosidade. Analisando as causas de sedimentação das partïculas de estearato de eritromicina no decorrer de sete dias, pelas Figuras 13 a 18 , observa-se que, quanto maior a viscosidade, menor é a instabilidade. Com relação à variação entre os trēs tipos de agente suspensor, - Viscosol ${ }^{R}$ RV, glicolato de amido sōdico, a $1,5 \%(p / v)$ não acusou separação de camada 1 împida da fase dispersante. De mais concentrações acusaram estabilidade entre 4 a 12 horas, com posterior aumento no volume de sedimento, estabilizandose a partir do segundo dia. Este fato pode sugerir que o es tearato de eritromicina apresente sedimentação do tipo compactado, pois, no caso de sistema desfloculado, hä sedimentação de partículas individuais, de maneira gradual, em função de seu tamanho (97). Entretanto, o perỉodo de observação foi muito curto para tal afirmação, uma vez que seria necessārio o período mínimo de 3 meses de acompanhamento das preparações.

A influēncia de Veegum ${ }^{R} H V$, silicato de aluminnio e magnésio, e Boniasol ${ }^{R} 2600$, carboximetilcelulose sódica, detectadas nas curvas das figuras 14 a 16 , indica haver diminu ição no volume de sobrenadante a partir da concentração de $1,2 \%$. Entretanto, estes dados obtidos em sistemas isolados não reproduzelil o mesmo comportamento quando incorporados na 
fórmula bāsica de suspensão, pelo fato de haver outras variā veis fisicas interferindo no resultado final. Basta verificar nas figuras 1 a 6 , cujas preparações sempre acusaram a flutuação das particulas. Por ëm, informações importantes fo ram conseguidas neste estudo prévio, as quais foram devidamente analisadas, a fim de modificar a formulação, com vistas ā preparação de novas amostras para acompanhamento mais pormenorizado e demorado.

Fundamentado em parâmetros encontrados, anteriormen te discutidos, recorreu-se à escolha de edulcorantes que apre sentassem densidade menor que a sacarose, a $51,0 \%$, quando uti 1izadas na mesma preparação. Pela Tabela VII (pāgina 51), per cebe-se que soluções de glicerina e sorbitol podem preencher este requisito. Além disto, segundo ROHDEWALD (92), estes edulcorantes apresentam a vantagem dupla pelo fato de propiciar molhabilidade de particulas.

Com relação aos agentes suspensores, preferiu-se a concentração de $1,2 \%(p / v)$, embora a de $1,5 \%(p / v)$ tivesse acusado maior volume de sedimento. Neste sentido SAMYN (96) afirma sobre a importāncia da concentração dos agentes suspensores, que deve ser a menor possivel, a fim de compatibiTizar-se com densidades inferiores a $1,1 \mathrm{~g} / \mathrm{mL}$, nos casos de particulas menores que $10 \mu \mathrm{m}$.

Como jā foi comentado anteriormente, jā que a dens $\underline{i}$ dade interfere na estabilidade de suspensões, tal caracterīs tica pode estar na dependēncia da natureza e concentração dos edulcorantes. As preparações de no 25 a 30 foram formuladas com $35 \%(p / v)$ de edulcorante representado por glicerina ou 
sorbito 1 , contendo como dispersante $1,2 \%$ de um dos 3 agentes suspensores. Estas preparações acusaram densidade com valor inferior a $1,110 \mathrm{~g} / \mathrm{mL}$. Porém, ao se analisar o comportamento das curvas das Figuras 19,20 e 23 a 26 , observa-se resul tado diferente em relação ao Boniasol ${ }^{R} 2600$, nas quais não ocorreu separação de fases. Em outros casos persistia flutu ação de partículas de estearato de eritromicina.

Nas preparações contendo Boniasol ${ }^{R} 2600$ não houve indỉcio de flutuação das partīculas e nem mesmo separação da camada sobrenadante lỉmpida. Entretanto, no estudo prévio, quando a concentração de glicerina foi de $35 \%$, havia flutuação das partículas de fármaco, conforme pode ser visto pela Figura 8 .

Com o intúito de diminuir a densidade da fase dispersante, a concentração de edulcorante foi ainda mais reduzida. Foram preparadas suspensões de nọ 31 a 36 , presentes na Tabela IV (página 41), contendo $30 \%(p / v)$ de edulcorante. As preparações de nọ 31 e 32 acusaram comportamento semelhan te às de $35 \%(p / v)$, como pode ser observado nas Figuras 25 e 26, não havendo diferenças no comportamento, em função da di minuição de $5 \%(p / v)$ no teor de edulcorante. No caso 33 e 34 , contendo Veegum ${ }^{R} H V$, o processo de sedimentação estacionou a partir de 15 e 7 semanas, respectivamente, segundo as Figuras acima citadas. Para as suspensões com Viscosol ${ }^{R}$ RV, preparações 35 e 36 , persistiu-se o problema da flutuação. Analisando-se as curvas da Figura 20 , estas preparações apre sentaram valores de $V f / V o$ constantes a partir de 20 semanas de armazenamento. 
Prosseguindo na experimentação, a fim de comprovar a relação entre redução de viscosidade e desaparecimento do problema da flutuação das partículas em questão, as concentrações de glicerina foram ainda mais reduzidas, empregandose 25 e $20 \%(p / v)$. Foram, respectivamente, as preparações de noss 47 e 41 (pägina 56), cujas curvas de estabilidade das mesmas constam das Figuras 21 e 22 .

No caso de nọ 41, houve dispersão perfeita de partỉculas até 8 dias; a partir disto ocorreu instabilização, havendo diminuição no valor de $V f / V o$ até 0,5 , em 16 semanas. o comportamento da preparação nọ 47 foi semelhante, mas com quebra de homogeneidade logo apōs a manipulação. Os valores de densidade e viscosidade não diferiram entre si. As que continham sorbitol na razão de 20 e $10 \%(p / v)$, quando na pre sença de Viscosol ${ }^{R}$ RV como agente suspensor (preparação no 42 e 48 (pägina 56), não apresentaram muita diferença nos va lores de densidade, bem como de viscosidade. Porém, nas de nọ 43 e 46, apesar da densidade estar na faixa de 1,030 e 1,070, houve sedimentação de partīculas. Dentre amostras que acusaram formação de sedimento de partỉculas, aquelas contendo Boniasol 2600 apresentaram estabilidade superior à quelas com Veegum ${ }^{R}$ RV. Percebeu-se que, mesmo naquelas sus pensões com teor de edulcorante de $30 \%$, o valor de Vs/Vo não foi abaixo de 0,73 , pois, as de no 45 e 46 apresentaram, res pectivamente, valor de 0,73 e 0,84 , com 30 semanas de obser vação.

Em relação aos parāmetros analiticos das suspensões com Viscosol ${ }^{R}$ RV (Tabelas XII e XIII, päginas 55 e 56), veri ficou-se variação considerāvel no tocante à viscosidade, após 
30 semanas de observação; este fato acarretou problemas no tocante à saìda do material pelo bocal do frasco. Esta alteração na viscosidade poderia ser associada à variação de pH, pois, segundo SABRA e DEASY (94), quando o valor de pH tende para alcalino, hā maior dissociação de grupos carbox $\bar{i}$ licos e hidroxilicos, propiciando a soluhilidade das macromoléculas de glicolato de amido sódico e, com isto, aumenta a viscosidade do sistema. Entretanto, estas suspensões não acusaram variaçăo nos valores de pH. Devido à modificação na viscosidade, a redispersão do sistema por recurso manual exigiu maior frequéncia de agitação, classificando-as na ca tegoria difícil. Mesmo sob agitação mecānica, houve necessidade de tempo superior a 40 minutos.

As suspensões à base de Viscosol ${ }^{R} R V$, quando submetidas à determinação de teor de eritromicina, apresentaram variação, pois, a de no 41 continha $147,33 \mathrm{mg} / 5 \mathrm{~mL}$, enquanto que a de $30,90,20 \mathrm{mg} / 5 \mathrm{~mL}$. Estes dados confirmam a não homogeneidade da suspensão, pois, quando da tomada de ensaio, verificou-se presença de aglomerados particulados, de difícil dispersão. Este asnecto jā havia sido observado durante a fase do estudo prévio, cujas curvas de instabilidade das Figuras 17 e 18 davam indícios sobre tipo da suspensão ser desfloculado.

Em relação às suspensões $25,26,31$ e 32 , contendo $1,2 \%$ de Boniasol ${ }^{R} 2600$ e 35 e $30 \%$ de edulcorante, não houve separação de fase com flutuação das partículas. Estas fórmulas, mesmo logo após a manipulação, apresentavam viscosidade acima de $1.100 \mathrm{cP}$, como pode ser visto pela Tabela XII. Com o intūito de diminuir o valor deste parāmetro, recorreu- 
se ao emprego de 1,1 e $1,0 \%(p / v)$ do mesmo agente suspensor, mantendo-se $30 \%$ de glicerina ou sorbitol. Considerou-se $1,0 \%$ como sendo concentração adequada, uma vez que a viscosidade inicial não foi elevada. Correspondem às preparações de no 37 e 38 (pägina 56), enquanto que 43 e 44 , com $1,1 \%$ não apre sentaram viscosidade satisfatória, como pode ser visto pelos dados da Tabela XIII (pag. 56).

Todas as preparações contendo Boniaso $7^{R} 2600$ não apresentaram separação de fases, mesmo com 30 semanas de observação. Este fato pode ser justificado pela explicação de HIESTAND (46), pois, a carboximetilcelulose sōdica, de conformaçăo molecular linear, quando em meio aquoso, mantém - se adsorvida na interface, propiciando a floculação do fárnaco disperso. Esta afirmação é corroborada por KELLAWAY e NAJIB (58), fato demonstrado em comparação ao polivinilpirrolidona (PVP), com conformação espiralada. Influem, por sua vez, o pH do sistema, sendo recomendáveis valores acima de 5,5. Va lores de pH mais ācidos são considerados, tambēm, compatîveis por SCHUMACHER (99), pois, estes afirmam como ideal desde 4 a 11. Nesta faixa, os grupos carboxilicos encontram-se totalmente ionizados, resultando a conformação linear da molécula. As preparações contendo carboximetilcelulose sódica, arroladas neste trabalho, acusaram pH acima do valor 6,4, sem muita alteração no decorrer do tempo. Apesar deste fato, hou ve acentuada diferença entre a viscosidade inicial e a de 30 semanas de envelhecimento. Este aumento chegou a acusar valores ao dobro do inicial, como ocorreu com as suspensões 25, 36 e 38. Comportamento deste tipo foi relatado por VAN OUDTSHOORN e POTGIETER (106) em suspensão de sulfadimidina 
contendo associação de CMC e Veegum. A viscosidade de 1.600 $c p$, após 16 semanas, passava a ser $3.550 \mathrm{cp}$. Este fenōmeno foi explicado por SCHUMACHER (99), como sendo decorréncia do rearranjo molecular de carboximetilcelulose sódica, gelificando-se com o passar do tempo. Esta caracterīstica è rever sīvel, devendo haver interferência física de agitação vigoro sa do sistema.

Apesar do aspecto homogéneo, à semelhança do tratamento de outras amostras, foi efetuada a agitação manual dos frascos contendo estas suspensões. Como envolveu, durante es te processo de agitação, mais de 11 inversões, atribuiu-se a classificação como sendo de difícil redispersão. Apesar disto, como este agente suspensor possui caracteristica reo1ōgica do tipo pseudoplāstico, quando submetido à agitação ví gorosa, ocorre alinhamento molecular, diminuindo a resistència em fluir $(1,75)$. Estranhamente, no estudo de JAMES e GODDARD (51) a concentração de carboximetilcelulose sōdica ha via sido $2,5 \%$ na suspensão de sulfato de bārio, concluindo apresentar, mesmo assim, maior facilidade de fluidez, que aquela contendo $1,83 \%$ de alginato sódico.

Analisando os dados da Tabela XII, no tocante à den sidade das dispersões, aquelas contendo Veegum ${ }^{R} H V$ (suspensões $27,28,33$ e 34 ) não foram discrepantes entre si, mas houve diferença na estabilidade ao longo do tempo. As de no 33 e 34 , com $30 \%$ de edulcorante, não mais apresentaram flutu ação das partĩculas, quando comparadas às de nọ 27 e 28 . Co mo a ünica diferença que estaria inftuenciando a inversão do posicionamento das particulas era devida à viscosidade, outras preparações foram obtidas, introduzindo outras concen- 
trações de Veegum ${ }^{R}$ HV. Estas, contendo 1,4 e $1,5 \%$ correspon dem às suspensões de no $39,40,45$ e 46 , conforme as fórmulas da Tabela V (pāgina 42) os valores de Vs/Vo, ilustradas nas Figuras 25 e 26 , indicam haver estabilidade a partir de apro ximadamente 2 semanas após a formulação.

As suspensões que continham Veegum ${ }^{R}$ HV em vez de Bo niasol 2600, mantiveram-se constantes quanto ao valor de vis cosidade, mesmo apōs 30 semanas, pois, a montmorrilonita pro picia a não compactação das partículas sedimentadas. Este agente suspensor, cujas lamelas cristalinas foram estrutura reticular volumosa, favorece a formação de gel com característica tixotrópica bastante acentuada $(19,75)$. Segundo es tes pesquisadores, a estrutura reticular volumosa assemelhase a "castelo de cartas".

As dispersōes à base de montmorrilonita são eficazes na faixa de pH de 6 a 9', embora a viscosidade máxima esteja na outra faixa, de 9 a 11 (2). Como as fórmulas testadas apresentavam pH dentro da primeira faixa (Tabelas XII e XIII), pode-se acreditar na eficiéncia máxima deste agente suspensor, como modificador da viscosidade do sistema. Podese dizer, então, que caracterīsticas desejāveis de estabilidade de suspensões foram incorporadas nestas preparações à base de Veegum ${ }^{R} H V$, seja na presença de sorbitol ou de glice rina. Este fato foi comprovado pela anāise quỉmica do teor de eritromicina, como se observa pelos dados da mesma Tabela.

Evidentemente que, no estudo de estabilidade fisica de suspensões, o tampo māximo para estabilização da curva é importante, além do volume de sedimento. Para TINGSTAD (104) 
a suspensāo apresentará estabìlîdade satisfatōria, quando o volume de sedimento não for inferior a $90 \%$ em relação ao ini cial. Entretanto, NASH (81) verificou fato diferente, pois, suspensões parenterais com 30 a $60 \%$ de volume do sedimento indicaram ser perfeitamente estáveis. Logo, no conceito de estabilidade de suspensões engloba-se a facilidade de redis persão ou rehomogeneização das partîculas, embora o volume ocupado pelo material particulado fosse pequeno. 


\section{CONCLUSOES}

7.1 - A inconveniència na flutuação do estearato de eritromicina depende da molhabilidade do fármaco e da densidade da fase dispersante.

7.2 - 0 EHL que apresentou melhores caracteristicas de molhabilidade e redispersão do estearato de eritromicina foi de 13, usando as associações de Polissorbato 60-span 60 e Polissorbato $80-5$ pan 80 .

7.3 - 0 fenōmeno da flutuação ocorre nas: soluções de edulcorantes e dispersões de agentes suspensores, quando estas apresentam densidades superiores a $1,110 \mathrm{~g} / \mathrm{mL}$.

7.4 - Suspensões contendo Viscosol ${ }^{R} R V$, como agente suspensor, parecem sugerir a não relação do fenōmeno da flutuação com a densidade da fase dispersante.

7.5 - Hā dispersão homogēnea do estearato de eritro micina nas suspensões contendo Boniaso ${ }^{R} 2600$ e como edulcorante glicerina ou sorbitol no decorrer de 30 semanas; entre tanto, as características reolögicas não foram adequadas no final do experimento.

7.6 - Suspensões contendo como agente suspensor Vee gum $^{R}$ HV e como edulcorantes glicerina ou sorbitol a $30 \%(p / v)$ apresentaram estabilidade adequada no tocante à facilidade de redispersão, viscosidade e tcor do fármaco disperso. 
1. ARANCIBIA, A. Consideraciones sobre la formulacion de sus pensiones farmaceuticas. Farmaco, Ed. Prat., Pavia, 26: $721-52,1971$.

2. BARR, M. Clays as dispersion stabilizer. J.Am. Pharm. Assoc., Sci. Ed., Washington, 4 : 180-3, 1964.

3. BARR, M. \& TICE, L.F. The preservation of aqueous preparations containing nonionic surfactants I. J. Am. Pharm. Assoc., Sci. Ed., Washington, 46: 442-5, 1957.

4. BARR, M. \& TICE, L. F. The preservation of aqueous prepa rations containing nonionic surfactants II. J.Am.Pharm. Assoc., Sci. Ed., Washington, 46: 445-51, 1957.

5. BERTUZZI, H.J. Tensoativo não iōnico na estabilização de suspensões. São Paulo, Faculdade de Ciências Farmacêu ticas da USP, 1980. (Dissertação-Mestrado).

6. BHATIA, R. P.; DESAI, K. T.; SHETH, B. B. Disintegration compressibility of tablets using CLD and other excipients. Drug. Cosmet. Ind., New York, 122(4): 38-52, 171-5, 1978 .

7. BONDI, J. V.; SCHNAARE, R. L.; NIEBERGALL, P. J.; SUJITA, E. T. Effect of adsorbed surfactant on particle-particle interactions in hydrophobic suspensions. J. Pharm. Sci. 62: $1731-3,1973$.

8. BRITISH pharmacopoeia. London, Her Majesty's Stationary office, 1973.

* De acordo com as normas preconizadas pela ASSOCIAÇAO BRASI LEIRA DE NORMAS TECNICAS (ABNT). As abreviaturas dos títulos de periódicos seguem o CHEMICAL ABSTRACTS SERVICE INDEX (CASSI), Columbus. 1979 . 
9. BRITISH pharmacopoeia. London, Her Majesty's Stationary office, 1980 .

10. CALCINARI, R. IL potenziale zeta e la sua importanza ne 1 la tacnologia farmaceutica. Farmaco, Ed. Prat., Pavia, 25: $24-8,1970$.

11. CARAMElLA, C.; COCHI, G. A.; CASTELLANI, P.; CONTE, U. ; COLOMBO, P.; LA MANM, A. The effect of some wetting agents on the characteristics of suspensions of sulfamethoxypyridazine and its N'acetyl derivative. Boll. Chim. Farm., Milan, 115:658-66, 1976 .

12. CARAMELLA, C.; COLOMBO, P.; CONTE, U.; LA MANNA, A. Rhe o logical analysis in the evaluation and prediction of the stability of suspensions. Farmaco, Ed. Prat., Pavia, 29: $318-32,1974$.

13. CARAMELLA, C.; CONTE, U.; COLOMBO, P.; COCCHI, G. A. Applicazione del1'analisi reologica allo studio della stabilita fisica di sospensioni di antibiotic. Boll. Chim. Farm.; Milan, 115: 702-13, 1976 .

14. CARAMElLa, C.; CONTE, U.; COLOMBO, P.; LA MANNA, A. A study on the electrokinetic properties of some chimotherapeutic drug suspensions. Farmaco, Ed. Prat. Pavia, 34: 295-305, 1979 .

15. CARSTENSEN, J. T. \& SU, K. S. E. Sedimentation kinetics of flocculated suspensions I: Initial sedimentation region. J.Pharm. Sci., Washington, 59: 666-70, 1970 .

16. CARSTENSEN, J.T. \& SU, K. S. E. Sedimentation kinetics of flocculated suspension II: Sedimentation belon the criticai height. J. Pharm. Sci., Washington, 59:671-6, 1970 .

17. CARSTENSEN, J. T. \& SU, S. E. Solvation of montmorilioni ie. 3. Pharm. Sci., Washington, 61: 139-4i, 1997. 
18. CASAdio, S.; PEREgo, R.; SLAVI, E.; TREU, I. Tecnologia farmaceutica. 2a ed., Milan, Cisalpino Goliardia, 1972 v. 1 p. 367-404.

19. CIULLO, P. A. Rheological properties of magnesium aluminum silicate/xanthan gum dispersions. J. Soc. Cosmet. Chem., New York, 32: 275-85, 1981.

20. CLARA ESKENASI, U. Obtenciōn de la carboximetilcelulosa sódica y sus aplicaciones. An. Fac. Bioquím. Univ.Fac. Mayor San Marcos, Lima, 5: 549-57, 1954.

21. COATES, D. Preservative/colloid interaction. Manuf.Chem. Aerosol News., London, 44: 34-7, 1973.

22. DAFFRE, C. Suspensões. IN: HELOU, J. H.; CIMINO, J. S. ; DAFFRE, C. Farmacotécnica. São Paulo, Artpress, 1975, p. $229-45$.

23. DENOEL, A. Aspects theoriques et pratiques de la preparation des emulsions et des suspensions en prescriptions magistrale. Farmaco, Ed. Prat., Pavia, 17: 243-79,1962.

24. DONDI, G. \& ZANOTTI GENEROSA, A. Influenza de11'a aggiun ta di sostanze stabillizzanti colloidali sulle proprie tá reologiche di una suspensione. Boll. Chim. Farm., Mi 1an, 120: 606-17, 1981 .

25. DU BAN, G. Recenti acquisizioni ne11 campo degli agenti tensoattivi e nella preparazione di sospensioni, emulsioni e solubilizzazioni. Part. I Boll. Chim. Farm., Milan, 102: 486-501, 1963 .

26. DU BAN, G. Recenti acquisizioni nel campo degli agenti tensioattivi e nella preparazione di sospensioni, emul sioni e solubilizzazioni. Part. II. Boll. Chem. Farm., Milan, 103: 287-98, 1964 .

27. ECANOW, B.; GRUNDMAN, R.; WILSON, R. Floculation and coagulation. Am. J. Hosp. Pharm., Washington, 23: 404, 1966 . 
28. ECANOW, B. \& TAKARURI, H. Flocculation theory and polysorbate 80-sulfaguanidine suspensions. J. Pharm. Sci., Washington, 59: 1848-9, 1970 .

29. ECANOW, B. \& WILSON, R. G. Powdered particle interactions: suspensions flocculation and caking II. J. Pharm. Sci., Washington, 52: 1031-8, 1963.

30. EVANS, W.P. The solubilisation and inactivation of preservative by nonionic detergents. J. Pharm. Pharmacol., London, 16: 323-31, 1964 .

31. FAIBRother, J. E. Analytical examination of hydrocolloids. Pharm. J., London, 223: 331-4, 1979.

32. FARLEY, C. A. \& LUND, W. Suspending agents for extemporaneous dispersing: Evaluation of alternatives to tragacanth. Phar. J., London, 216: 562-6, 1976.

33. FARMACOPEIA brasileira. 3. ed. São Paulo, organização Andrei, 1977 .

34. FARMAcopeia dos Estados Unidos do Brasi1.2. ed. São Pau10, Indūstrias Grāficas Siqueira, 1959.

35. FEDORS, F. R. Relationships between viscosity and concen trations for newtonian suspensions. J. Colloid Interface Sci., New York, 46 : 545-7, 1974.

36. FOERNZLER, E. C.; MARTIN, A. N.; BANKER, G. S. The effect of thixtropy on suspension stability. J. Pharm. Assoc. Sci. Ed., Washington, $\underline{49}$ : 249-52, 1960 .

37. FRITZ, H. \& BECKER, H. The suitability of carboximethylcellulose as a vehicle in reproductive studies. Arzneim Forsch., Aulendorf, 31(5): 813-5, 1981.

38. GERDING, P.W. \& SPERANDIO, G. J. The determination of the relative efficienty of suspending agents. Drug stand, Washington, 21: 215-21, 1953 . 
39. GOLDSTEIN, S.W. A hydrophilic suspension vehicle. J.Am. Pharm. Assoc., Pract. Pharm. Ed., Washington, 13: 550-2, 1952 .

40. GOLDSTEIN, S. W. Ce 11 UTose derivates as aids in extemporaneous compounding. J.Am. Pharm. Assoc., Pract.Pharm. Ed., Washington, 14: 111-4, 116. 118, 1953.

41. GRIFFIN, W. C. Classification of surface-active agents by EHL. J. Soc. Cosmet. Chem., New York, l: 311-326, 1949 .

42. Guimaraes, E. M. P.; SANTOS, M. M.; BARDUK, 0.; PINTO, T. J. A.; BERTUZZI, H. J.; SAITO, T. Eficácia de conservantes em suspensão de cautim. Rev. Farm. Bioquím.Univ. São Pau1o, 18(1): 28-38, 1982 .

43. GYSELINCK, P.; REMON, J. P.; van SEVEREN, R.; BRAECKMAN, $P$. Metil-en carboxymethylcelulose in de receptur verband concentratie - type - viscositeit. Farm. Tijschr. Belg., Brusse1s, 58: 37-46, 1981.

44. HABERLE, J. E. Calamine lotion prepared with microcrystal line cel1u1ose. Am. J. Hosp. Pharm., Washington, 25: $180-2,1968$.

45. HAINES, B. A. Jr. \& MARTIN, A. N. Interfacial properties of powdered material; caking in liquid dispersion I. Caking and flocculation studies. J. Pharm. Sci., Washington, 50: 228-32, 1961 .

46. HIESTAND, E. N. Theory of coarse suspension formulation. J.Pharm. Sci., Washington, 53: 1-18, 1964.

47. HIESTAND, E. N. Physical properties of coarse suspensions. J. Pharm. Sci., Washington, 61: 268-72, 1972.

48. HIGUCHI, T. Some physical chemical aspects of suspension formulation. J.Am. Pharm. Assoc., Sci. Ed., Washington, 47: $657-60,1958$. 
49. HIGUCHI, T. \& BROCHMANN-HANSEEN, E. Pharmaceutical analysis. New York, Interscience, 1961, p. 200.

50. IDSON, B. \& BACHYNSKY, M. D. Natural raw materials in sem i - solid dosage forms. Drug cosmet. Ind. New York, 122: $38,44,153-4,1978$.

51. JAMES, A. M. \& GODDARD, G. H. Barium meals: A physical chemical study of the adsorption of hydrocolloids by barium sulphate. Pharm. Acta Helv., Zurich, 47: 244-56, 1972 .

52. JONES, R. D. C.; MATTHEWS, B. A.; RHODES, C. T. Physica 1 stability of sulfaguanidine suspensions. J. Pharm. Sci. Washington, 58: 518-20, 1970 .

53. KABBRE, S.P.; DEKAY, H. G.; BANKER, G. S. Rheology and suspension activity of pseudoplastic polymers II. Comparison of suspension activity of pseudoplastic polymers at fixed viscosities. J. Pharm. Sci., Washington, 53: $495-9,1964$.

54. KAYES, J.B. The effect of surface active agents on the zeta potential of particles in a model suspension sys tem. J.Pharm. Pharmacol., London, 25(supp 1): 164 p, 1973.

55. KAYES, J.B. Pharmaceutical suspension:micro electrophoretic properties. J.Pharm. Pharmaco1., London, 29:1638,1977 .

56. KAYES, J.B. Pharmaceutical suspensions: relation between zeta potencial, sedimentation volume and suspension sta bility. J. Pharm. Pharmacol., London, 29: 199-204, 1977.

57. KAZMI, S. J.A. \& MICHELL, A. S. Preservatives of solubif ized and emulsified systems. I. Correlation of mathemat ically predict preservative availability with antimicrobial activity. J. Pharm. Sci., Washington, 67: 1260= 6,1978 . 
58. KELLAWAY, I. W. \& NAJIB, N. M. Hydrophilic polymers as stabilizers and flocculants of sulphadimidine suspension. Int. J. Pharm., London, 9. 59-66, 1981.

59. KENNEDY, D. L.; FORBES, B. F.; BAUM, C.; JONES, J.K. Antibiotic use in U.S. Hospitals in 1981. Am J. Hosp. Pharm., Washington, 40: 797-801, 1983 .

60. KHAN, K. A. \& RHODES, C. T. Water-sorption of tablets desintegrants. J. Pharin. Sci., Washington, 64: 447-51, 1975 .

61. KOROLKOVAS, A. \& BURCKHALTER, J. H. Química Farmacéutica Rio de Janeiro, Guanabara Dois, 1982, p. 575.

62. LACHMAN, N. L.; LIBERMAN, H. A.; KANIG, J. L. The theory and practice of industrial pharmacy 2. ed., Philadéphia, Lea \& Febiger, 1976, p. 162-83,

63. LESSHAFFT, C. T. Jr. \& DEKAY, H. G. Comparison of the suspending agents. J.Am. Pharm. Assoc., Pract. Pharm. Ed., Washington, 15: 410-3, 1954 .

64. LESSHAFFT, C. T., Jr. \& DEKAY, H. G. A study of the compatibility of various suspending agents. Drug Stand., Washington, 22: 155-64, 1954 .

65. LOWENTHAL, W. Metrology and Calculation IN: OSOL, A. \& HOOVER, J. E. Remington's Pharmaceutical Sciences, 15a ed., Easton, Mack Publishing Company, 1975, p. 75116 .

66. MANSOUR, $Z$ \& GUTH, E. P. Complexing behavior of starches with certain pharmaceutical. J. Pharm. Sci., Washington, 57: $404-11,1957$.

67. MARTIN, A. N. Principios de fisico-química para farmacodinamica y biologia. Madri, Editorial Alhambra, 1976 , p. $617-38$. 
68. MARTIN, A. N. Physical chemical approach to the formulation of pharmaceutical suspensions. J. Pharm. Scï., Washington, 50: $513-7,1961$.

69. MARTINDALE, W. H. The extra pharmacopeia. 28. ed., London, Pharmaceutical Press, 1982, p. 961.

70. MATTHEWS, B. A. Orthokinetic coagulation in pharmaceutical suspensions. J. Pharm. Sci., Washington, 62: 172-4, 1973.

71. MATHEWS; B. A. \& RHODES, C. T. Some studies of flocculations phenomena in pharmaceutical suspensions. J. Pharm. Sci., Washington, 57: 569-73, 1968.

72. MATHEWS, B. A. \& RHODES, C. T. Use on the Derjaguin, Lan dau, Verwey and Overbeek theory in interpret pharmace $\underline{u}$ tical suspension stability. J. Pharm. Sci., Washington, 59: $521-5,1970$.

73. MENDELL, E. An evaluation of carboxymethyl starch as dis integration. Pharm. Acta Helv., Zurich, 49: 248-50,1974 .

74. MIYAWAKI, G. M.; PATEL, N. K.; ' KOSTENBALIDER, H. B. Interaction of preservatives with macromolecules III: Parahydrobenzoic acid esters in presence of some hydro philic polymers. J.Am. Pharm. Assoc., Washington, 48: $315-8$, i959.

75. MOËS, A. Aspects theoriques et pratiques de la formulation des suspensions. Farmaco, Ed. Prat., Pavia, 22: 119-51, 1967 .

76. MOËS, A. Preparation de suspensions stables de sulfamidi ne et de palmitate de chloramphenicol. Etude thēorique et pratique. Pharm. Acta Helv., Zurich, 43: 290320,1968 .

77. MOÉS, A. Influence de la méthode de movillage des particu les sur les proprietés rhēologiques et la stabilitē 
physique des sucpensions de sulfamide. Pharm. Acta Helv., Zurich, 45: 101-10, 1970 .

78. MOËS, A. Nouveaux agents epaississant dans la formulation des suspensions, des emulsions et des gelees. Farmaco, Ed. Prat., Pavia, 27: 119-46, 1972 .

79. MURANYL, A. A pelyhesītēs (flokkulāiatatās) mint a gyōgyszeres szuszpenziōk elōāllitāsānak ūj mōdszere. Gyogyszereszet, Budapest, 23: 132-5, 1979.

80. NASH, R. A. The pharmaceutical suspensions Part. I. Drug Cosmet. Ind., New York, 97: 843-6, 939, 942-4, 947-8, $950-1,1965$.

81. NASH, R. A. The pharmaceutical suspensions Part.II. Drug Cosmet. Ind., New York, 98: 39-40, 43, 128-33, 1966.

82. NASH, R. A. \& HAEGER, B. E. Zeta potencial in the development of pharmaceutical suspensions. J. Pharm.Sci., Washington, 55: 829-37, 1966 .

83. PATEL, M. K. \& KOSTENBAUDER, H. B. Interaction of preservatives with macromolecules I. Binding of parahydro xybenzoic acid esters by polyoxythylene 20 sorbitan mo noleate (Tween 80). J. Am. Pharm. Assoc., Sci.Ed., Washington, 47: 289-93, 1958.

84. PHARMACOPEIA of the United States of America. XX ed. National Formulary XV Rockville, United States Pharmacopeial Convention, 1980.

85. POELMAN, M. C.; CHAUMEIL, J. C.; PLUSIEUX, F. Les interactions entre antisseptiques esters de sortitanne polyoxēthylenes par le méthode des solubilitēs. Ann. Pharm. Fr., Paris, 32: 594-604, 1972.

86. POLDERMAN, J. Suspensions in pharmaceutical pratice. Bo! 1. Chim. Farm., Mi 1an, 101: 105-20, 1962. 
87. PRISTA, L. N. \& ALVES, A. C. Tecnologia farmacēutica, Farmácia gaténica. Lisboa, Fundação Calouste Gulbenkian, 1967, v. 1, p. 1073-131.

88. REBER, L. A. Colloidal dispersions IN: OSOL, A. \& HOOVER, J. E. Remington's Pharmaceutical Sciences, 15 a ed., Easton, Mack Publishing Company, 1975, p. 299-321.

89. REES, J. E. Formulations of medicines for oral administration. Pharm. J., London, 213: 266-71, 1974.

90. REES, J. E. Characterisation of pharmaceutical particulate materia1s. Bol1. Chim. Farm., Mi1an, 116:125-41, 1977 .

91. RIGAMONTI, S. \& RUGGINENTI, G. Le sospensioni farmaceti che. Farmaco, Ed. Prat., Pavia, 24: 445-89, 1969.

92. ROHDEWALD, P. Quality of suspensions. Cosmet. Perfum., oak Park, 90: 35-45, 1975.

93. RUNIKIS, J. O.; HALL, N. A.; RISING, L. W. A note on the use of the Brookfield RVF vicometer with thickening agent dispersions. J. Am. Pharm., Assoc. Sci. Ed., washington, 47: 758-9, 1958.

94. SABRA, K.; DEASY, P. B. Rheological and sedimentation studies on Instant Clearjel and Primogel suspensions. J. Pharm. Pharmacol., London, 35: 275-8, 1983.

95. SAKUDA, T. M.; OHARA, M. T.; BERTUZZI, H. J.; SAITO, T. Eficiência de conservantes em duspensão de caulim I . Ácido benzōico, benzoato de sōdio e Nipaset ${ }^{R}$. Rev. Bras. Farm., São Pau10, 8: 63-67, 1983.

96. SAMYN, J. C. An industrial approach to suspensions formulation. J.Pharm. Sci., Washington, 50: 517-22, 1961.

97. SCHEER, A. J. Practical guidelines for suspensions formu 1ation. Drug Cosmet. Ind. New York, 128: 40-4, 116, 1981. 
98. SCHNEIDER, W.; STAVCHANSKY, S.; MARTIN, A. Pharmaceutical suspensions and the DLVo theory. Am. J. Pharm. Ed. Bethesda, 42: 280-9, 1978 .

99. SHUMACHER, G. E. The bulk compounding technology of $1 \mathrm{iq}$ uids and semi-solids. Am. J. Hosp. Pharm., Washington, 26: $7 .-99,1969$.

100. SHUMACHER, G. E. Theorical aspects of bulk compounding te chnology II. Suspensions. Am. J. Hosp. Pharm., Washington, 26: 548-50, ?969.

101. SU, K. S. E. \& CARSTENSEN, J. T. Nature of bonding in montmorillonite adsorbates II. Bonding as a ion dipole interaction. J. Pharm. Sci., Washington, 61: 4204,1972 .

102. SWABRICK, J. Coarse Dispersion IN: OSOL, A. \& HOOVER, J. E. Remington's Pharmaceutical Sciences 15a ed. Easton, Mack Publishing Company, 1975, p. 299-321.

103. TAGLIAPIETRA, L. Studio sul potere antimicrobico delle preparazione farmaceutiche liquide e semisolide. Boll. Chim. Farm., Milan, 116: 24-33, 1977.

104. TINGSTAD, J. E. Physical stability testing of pharmaceu tica1s. J. Pharm. Sci., Washington, 53: 955-62, 1964 .

105. VAN DOTEGHEM, M. La division des poudres en cachets et ge1ules. J.Pharm. Belg., Bruxe 1s, 21: 73-85, 1966.

106. VAN OUDTSHOORN, M. C. B. \& POTGIETER, F. J. The formula tion and evaluation of two sulphadimidine suspensions. Pharm. Weekb 1., Amsterdan, 105: 909-15, 1971.

107. VON ASCHE, H. Beitrag zur Viskositätsmessung pseudoplastischer substanzen. Erfahrungen bei Erfassung und Vergleich von Messwerten mit verschiedenen Viskosimetern. Pharma. Acta., Zurich, 49: $277=84,1374$. 
108. WALKER, C. W. \& WELL, J. I. Rheological synergism between ionic and non-ionic cellulose gums. Int. J. Pharm., London, 11: 309-22, 1982 .

109. WILSON, P. Physical stability of sulphaguanidine suspensions. J. Pharm. Pharmaco 1., London, 28(Supp 1.):29 $p, 1976$.

110. WILSON, R. G. \& ECANOW, B. Powdered particle interactions: suspensions flocculation and caking IV. J. Pharm. Sci., Washington, 53: 913-6, 1964 .

111. YABLONSKI, J. I. Strategies for cosmetic preservation. Cosmet. Toiletries, 0ak Par, 92: 22-31, 1977.

112. ZACEK, H. J. Relation between dispersibility and adherence of powdered medicinal substances in liquid medium. J. Pharm. Pharmaco1., London, 12: 191-2, 1960.

113. ZATZ, J.L. \& LUE, R. Y. Effect of polyols on physical stability of suspensions containing nonionic surfactant. J. Soc. Cosmet. Chem., New York, 33: 149-55, 1982.

114. ZOGRAFI, G. Interfacial phenomena IN: OSOL, A. \& HOOVER, J. E. Remington's Pharmaceutical Sciences, 15a ed., Easton, Mack Pubiishing Company, 1975, p 285-98. 
9 RESUMO

As suspensões de estearato de eritromicina, de pro cedēncia nacional, apresentam a inconveniēncia que reside na elevada viscosidade ou flutuação do fármaco disperso. Fo ram estudados diferentes adjuvantes farmacotécnicos, a fim de verificar fatores interferentes que poderiam melhora a estabilidade da suspensão de estearato de eritromicina. Co mo agentes suspensores foram utilizados Boniasol ${ }^{\mathrm{R}} 2600$ (carboximetilcelulose sōdica), Veegum ${ }^{R}$ HV (silicato de aluminio e magnésio) e Viscosol ${ }^{R} R$ (glicolato de amido sódico) e como edulcorantes a glicerina, sorbitol a $70 \%$ e sacarose. As determinações analiticas para avaliar a estabilidade das suspensões foram: pH, densidade, viscosidade, aspecto da suspensão, volume do fármaco disperso, caracterīsticas de ressuspensão e doseamento do antibiōtico. As suspensões con tendo Boniasol ${ }^{R} 260$ e glicerina ou sorbitol não apresentaram o fenômeno da flutuação. As preparações contendo veegum ${ }^{R V}$ e glicerina ou sorbitol na concentração de $30 \%$ ( $p / v)$ apresen taram estabilidade adequada. 


\section{Summary}

Suspensions of erithromycin stearate of national origin present the inconvenience of the high viscosity or of the flotation of the dispersed drug. Different pharma ceutical helpers were studied in order to verify of the erythromycin stearate suspension. Boniasol ${ }^{R} 2600$ isodium carboxymethyl celluzose), Veegum ${ }^{R}$ HV (aluminum magnesium silicate) and Viscosol ${ }^{R} R V$ (sodium stapch glycollate) were used as suspending agents and glycerin, sorbitol at 70\% and sucrose were used as sweeteners. Analytic deter mination to evaluate the suspensions stability were: $p H$, density, viscosity, aspecto of suspension, volume of the dispersed drug, resuspension characteristics and determination of the antibiotic dose. Suspensions containing Boniasol 2600 and glycerin or sorbitol didn't present floatation. Preparation with veegum ${ }^{R} H$ and glycerin or sorbitol in a concentration of $30 \%(p / v)$ presented adequate stabizity. 